ALEXANDRE GOMES RODRIGUES

\title{
APLICAÇÃO DE FUNGOS DE MANGUEZAIS NA OBTENÇÃO DE NANOPARTÍCULAS DE PRATA COM AÇÃO ANTIMICROBIANA
}

Dissertação apresentada ao Programa de PósGraduação Interunidades em Biotecnologia USP/Instituto Butantan/IPT, para obtenção de

Título de Mestre em Biotecnologia. 


\section{ALEXANDRE GOMES RODRIGUES}

\section{APLICAÇÃO DE FUNGOS DE MANGUEZAIS NA OBTENÇÃO DE NANOPARTÍCULAS DE PRATA COM AÇÃO ANTIMICROBIANA}

Dissertação apresentada ao Programa de PósGraduação Interunidades em Biotecnologia USP/Instituto Butantan/IPT, para obtenção de Título de Mestre em Biotecnologia.

Área de concentração: Biotecnologia

Orientadora: Profa. Dra. Ana Olívia de Souza

Versão original 
DADOS DE CATALOGAÇÃO NA PUBLICAÇÃO (CIP)

Serviço de Biblioteca e Informação Biomédica do

Instituto de Ciências Biomédicas da Universidade de São Paulo

reprodução não autorizada pelo autor

Rodrigues, Alexandre Gomes.

Aplicação de fungos de manguezais na obtenção de nanopartículas de prata com atividade antimicrobiana / Alexandre Gomes Rodrigues. - São Paulo, 2013.

Orientador: Profa. Dra. Ana Olívia de Souza.

Dissertação (Mestrado) - Universidade de São Paulo. Instituto de Ciências Biomédicas. Programa de Pós-Graduação Interunidades em Biotecnologia USP/IPT/Instituto Butantan. Área de concentração: Biotecnologia. Linha de pesquisa: Nanobiotecnologia.

Versão do título para o inglês: Application of mangrove fungi in obtaining silver nanoparticles with antimicrobial activity.

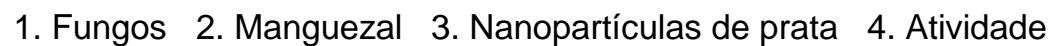
antibacteriana 5. Atividade antifúngica I. Souza, Profa. Dra. Ana Olívia de II. Universidade de São Paulo. Instituto de Ciências Biomédicas. Programa de Pós-Graduação Interunidades em Biotecnologia USP/IPT/Instituto Butantan III. Título. 
Candidato(a): $\quad$ Alexandre Gomes Rodrigues.

Título da

Aplicação de fungos de manguezais na obtenção de nanopartículas de prata com atividade antimicrobiana.

Orientador(a): $\quad$ Profa. Dra. Ana Olívia de Souza.

A Comissão Julgadora dos trabalhos de Defesa da Dissertação de Mestrado, em sessão pública realizada a .................................................., considerou
( ) Aprovado(a)
( ) Reprovado(a)

Examinador(a): Assinatura:

Nome:

Instituição:

Examinador(a): Assinatura:

Nome:

Instituição:

Presidente: Assinatura:

Nome:

Instituição: 
Protocolo: I-947/12

Dr. Ana Olívia de Souza

Laboratório de Bioquímica e Biofísica

Instituto Butantan

São Paulo, 22 de junho de 2012.

Referente Projeto: "Estudo do potencial de fungos de manguezais na biossíntese de nanopartículas de prata e aplicação em tecidos antimicrobianos".

A Comissão de Ética no Uso de Animais do Instituto Butantan (CEUAIB) informa que o projeto acima referido é isento de análise por parte desta Comissão, pois não faz uso de animais vertebrados em sua execução.

Cordialmente,

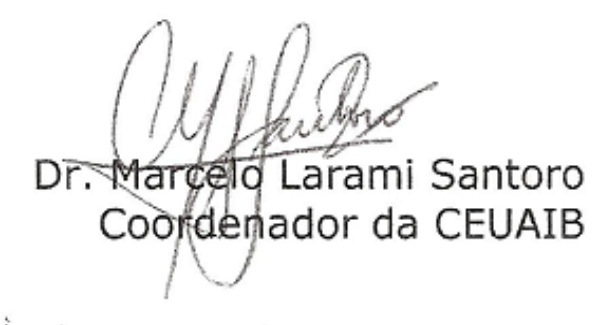


A todas as pessoas que passaram por minha vida, levando um pouco de mim e deixando um pouco de si. 


\section{AGRADECIMENTOS}

À Profa. Dra. Ana Olívia de Souza por aceitar me orientar, pela dedicação, paciência, amizade, empenho e interesse no desenvolvimento do trabalho.

À minha família que sempre me apoiou e compreendeu minhas ausências.

À Yu Ping Liu pela amizade, importante colaboração em muitos momentos, especialmente na identificação dos fungos, pela presteza e carinho, e também pelas comidas chinesas.

À Orlando Giarletti pela amizade, paciência, discussões e contribuições que muito, e sempre ajudaram a enriquecer meu modo de pensar, e pelas poucas partidas de ping pong.

À Rafael Marques Porto pela amizade sempre enriquecedora e pelas longas e boas conversas.

À Profa. Dra. Adriana Rios pela constante disponibilidade, pelo carinho e gentileza.

Ao Prof. Dr. Daniel Pimenta pelas conversas e disposição em dar opiniões pertinentes.

À Profa. Dra. Lujbica Tasic pela colaboração nos experimentos de caracterização das proteínas e discussões enriquecedoras.

Ao Dr. Itamar Soares Melo por fornecer as cepas dos fungos de mangue e se mostrar sempre prestativo e atencioso.

Ao Dr. Ivo Lebrun por me acolher no Laboratório de Bioquímica e Biofísica.

À Profa. Dra. Rita Ruiz pela colaboração nos experimento de atividade antibacteriana.

À Profa. Dra. Priscyla D. Marcato pela colaboração nos experimentos de Microscopia Eletrônica e pela ajuda sempre que possível.

Aos professores Wellington Luiz de Araújo, Maria Filomena de Andrade Rodrigues e Paulo Roberto Regazi Minarini pela participação no Exame de Qualificação, com valiosas contribuições.

Aos funcionários da secretaria do Programa de Pós Graduação, que sempre estiveram à disposição e sempre ajudaram de todas as formas.

À CAPES pelo importante apoio financeiro. Assim como a FAPESP pelo apoio financeiro ao projeto. 
Silêncio

um
pequeno sorriso
que salta
da monotonia
para tornar
a vida
uma cena
diferente
daquele dia
repetido
um novo
modo de
olhar
separando
os verbos
das velhas
flores
e manias
que assustam
a vida
de uma
alma
inquieta.

Sasha Y. Dichter 


\section{RESUMO}

RODRIGUES, A. G. Aplicação de fungos de manguezais na obtenção de nanopartículas de prata com ação antimicrobiana. 2013. 106 f. Dissertação (Mestrado em Biotecnologia) Instituto de Ciências Biomédicas, Universidade de São Paulo, São Paulo, 2013.

Infecções hospitalares constituem um problema de saúde pública em países não desenvolvidos. Considerando a gravidade e consequências das infecções hospitalares, vestimentas hospitalares e materiais médicos que proporcionem a eliminação ou redução da presença de microrganismos têm sido estudados. A prata $\left(\mathrm{Ag}^{+}\right)$é um metal que apresenta ação antimicrobiana de amplo espectro e limitada toxicidade em humanos. $\mathrm{Na}$ forma de nanopartícula tem maior reatividade devido ao aumento da superfície de contato. Nanopartículas de prata (NP Ag) podem ser obtidas por métodos químicos e físicos, porém com uso de reagentes tóxicos e grande consumo de energia. Métodos biológicos representam uma alternativa para obter nanoparticulas metálicas. Neste trabalho quatorze linhagens de fungos isolados de mangue foram avaliadas quanto ao potencial de síntese de NP Ag com atividade antimicrobiana. Os fungos foram cultivados sob agitação por 72 horas em meio líquido batata dextrose (BD). À biomassa foi adicionada água destilada estéril. Após 72 horas a suspensão foi filtrada. O filtrado fúngico (FF) foi utilizado para a síntese de NP Ag na presença de $\mathrm{AgNO}_{3}$ e dois fungos foram selecionadas para a continuidade do estudo. A caracterização físico-química das nanopartículas foi realizada por espectrofotometria, microscopia eletrônica de transmissão e espectroscopia de correlação de fótons. A banda de plasmon na região de $440 \mathrm{~nm}$ evidenciou a formação de NP variando entre 10-30 nm. O potencial zeta foi positivo para as NP Ag de MGE-201 e negativo para NP de L-2-2. A presença e identificação de proteínas na dispersão de nanopartículas foram feitas por eletroforese em gel de poliacrilamida - dodecil sulfato de sódio (SDS - PAGE) e cromatografia líquida acoplada à espectrometria de massas (LC/MS). A análise das proteínas presentes no FF e na dispersão de nanopartículas de L-2-2 em SDS-PAGE revelou a presença de três e quatro bandas com massa molecular na faixa de 25 a $174 \mathrm{Da}$, respectivamente. No FF e dispersão de NP Ag de MGE-201 foram encontradas quatro bandas com massa molecular de 75 a $328 \mathrm{Da}$. Nove proteínas foram detectadas por LC/MS na dispersão de NP de MGE-201. A ação antimicrobiana das nanopartículas foi avaliada em oito espécies de Candida e em quatro bactérias. As nanopartículas foram mais efetivas nas espécies de $C$. guilhermondi, $C$. parapsilosis, $P$. aeruginosa e $S$. aureus com concentrações inibitórias mínimas variando de 0,015 a $0,132 \mu \mathrm{g} / \mathrm{mL}$. A citotoxicidade foi avaliada em macrófagos $\mathrm{J} 774$ e em hepatócitos de ratos. NP Ag de L-2-2 e MGE-201 apresentaram $\mathrm{IC}_{50}$ de 5,5 e $26 \mu \mathrm{g} / \mathrm{mL}$ em macrófagos e de 26 e $17 \mu \mathrm{g} / \mathrm{mL}$ em hepatócitos, respectivamente. Tecidos de algodão e de poliéster foram impregnados com NP Ag e a porcentagem de impregnação determinada por plasma indutivamente acoplado (ICP) variou de $0,1-12,5 \%$. A ação antifúngica dos tecidos impregnados foi testada em $C$. albicans ATCC 36802, C. glabrata IOC 4565 e $C$. parapsilosis IOC 4564 com inibição do crescimento dos patógenos na faixa de 68,41 - 97,91 $\%$. Em E. coli e $S$. aureus a inibição do crescimento foi de $100 \%$ na concentração de 2,2 $\mu \mathrm{g} / \mathrm{mL}$. Os fungos codificados como L-2-2 e MGE-201 foram identificados como Bionectra ochroleuca e Aspergillus tubingensis, respectivamente.

Palavras-chave: Fungos. Manguezal. Nanopartículas de prata. Atividade antibacteriana. Atividade antifúngica. 


\begin{abstract}
RODRIGUES, A. G. Application of mangrove fungi in obtaining silver nanoparticles with antimicrobial activity. 2013. 106 p. Masters thesis (Biotechnology) - Instituto de Ciências Biomédicas, Universidade de São Paulo, São Paulo, 2013.

Hospital infections constitute a public health problem in undeveloped countries. Considering the severity and consequences of nosocomial infections, hospital clothing and medical devices that provide the elimination or reduction of microorganisms have been studied. Silver $(\mathrm{Ag}+)$ is a metal that has broad spectrum antimicrobial activity and limited toxicity in humans. In nanoparticles form silver has higher reactivity due to increased contact surface. Silver nanoparticles (Ag NP) can be obtained by chemical and physical methods, but with drawbacks such as the use of toxic reagents and large energy consumption. Biological methods represent an alternative to obtain metal nanoparticles. In this study fourteen strains of fungi isolated from the mangrove were evaluated regarded to their capacity to synthesize Ag NP with antimicrobial activity. The fungi were cultivated for 72 hours in potato dextrose liquid medium (PD). Distilled sterile water was added to the biomass. After $72 \mathrm{~h}$ the suspension was filtered. The fungal filtrate $(\mathrm{FF})$ was used to synthesize silver nanoparticles in the presence of $\mathrm{AgNO}_{3}$ and two fungi were selected to continue the work. The physicochemical characterization was performed by spectrophotometry, transmission electron microscopy and photon correlation spectroscopy. The plasmon band in the region of $440 \mathrm{~nm}$ evidenced the formation of nanoparticles ranging from 10-30 nm. The zeta potential was positive for Ag NP of MGE-201, and negative for NP L-2-2. The presence and identification of the proteins in the nanoparticles dispersion were performed by sodium dodecyl sulfate polyacrilamide gel electrophoresis (SDS - PAGE) and Liquid Chromatography - Mass Spectrometry (LC/MS) analysis. The analysis of the proteins in the FF and in the NP dispersion by SDS - PAGE revealed the presence of three and four bands with mass ranging from 25-174 Da, respectively. In the FF and Ag NP dispersion of MGE-201 four bands ranging from 75-328 Da were found. Nine proteins were detected by LC/MS in MGE-201 nanoparticles dispersion. The antimicrobial activity of the nanoparticles was evaluated against eight Candida species and four bacteria. The NP were more effective against the $C$. guilhermondi, $C$. parapsilosis, $P$. aeruginosa e $S$. aureus especies with minimum inhibitory concentrations from 0.015 to $0.132 \mu \mathrm{g} / \mathrm{mL}(1.3 \mathrm{a} 12 \mu \mathrm{M})$. The citotoxicity was evaluated on J774 macrophages and rat hepatocytes. Ag NP presented $\mathrm{IC}_{50}$ of 5.5 and $26 \mu \mathrm{g} / \mathrm{mL}$ in macrophages and of 26 e $17 \mu \mathrm{g} / \mathrm{mL}$ in hepatocytes, respectively. Cotton and polyester fabrics were impregnated with $\mathrm{Ag} \mathrm{NP}$ for one, two and four times, and the percentage of impregnation was determined by inductively coupled plasma (ICP), varying from $0.1-12.5 \%$. The antifungal activity of the fabrics impregnated with Ag NP was tested against $C$. albicans ATCC 36802, C. glabrata IOC 4565 and $C$. parapsilosis IOC 4564, presenting inhibition from $68.41-97.91 \%$. Against E. coli and S. aureus the growth inhibition was of $100 \%$ in the concentration of $2.2 \mu \mathrm{g} / \mathrm{mL}$. The L-2-2 and MGE-201 coded fungi were identified as Bionectra ochroleuca and Aspergillus tubingensis, respectively.
\end{abstract}

Keywords: Fungi. Mangrove. Silver nanoparticles. Antibacterial activity. Antifungal activity. 


\section{LISTA DE SÍMBOLOS E ABREVIATURAS}

\begin{tabular}{|c|c|}
\hline$\mu \mathrm{g}$ & Micrograma \\
\hline$\mu 1$ & Microlitro \\
\hline${ }^{\circ} \mathrm{C}$ & Grau Célsius \\
\hline$\%$ & Percentagem \\
\hline $\mathrm{Ag}$ & Prata \\
\hline $\mathrm{Ag}+$ & Prata \\
\hline $\mathrm{Ag}_{2} \mathrm{~S}$ & Sulfeto de prata \\
\hline $\mathrm{AMB}$ & Anfotericina B \\
\hline ATCC & American Type Culture Collection \\
\hline $\mathrm{BD}$ & Batata dextrose \\
\hline BDA & Batata dextrose ágar \\
\hline BSA & Bovine Serum Albumine \\
\hline CBS & Center for Biological Sequence \\
\hline CIM & Concentração Inibitória Mínima \\
\hline $\mathrm{CFU}$ & Colony forming units \\
\hline $\mathrm{Da}$ & Dalton \\
\hline DNA & Deoxyribonucleic acid \\
\hline dNTP & Deoxiribonucleotide triphosphates \\
\hline DMEM & Dulbecco's Modified Eagle Medium \\
\hline DMSO & Dimetilsulfóxido ou sulfóxido de dimetilo \\
\hline EDTA & Ethylenediamine tetraacetic acid \\
\hline FF & Filtrado fúngico; fungal filtrate \\
\hline FTIR & Fourrier Transformed Infra Red \\
\hline $\mathrm{g}$ & Grama \\
\hline $\mathrm{H}_{2} \mathrm{~S}$ & Ácido sulfídrico \\
\hline
\end{tabular}




\begin{tabular}{|c|c|}
\hline HL-60 & Human promyelocytic leukemia cells \\
\hline $\mathrm{Hz}$ & Hertz \\
\hline $\mathrm{ICP}$ & Inductively coupled plasma \\
\hline IOC & Instituto Oswaldo Cruz \\
\hline $\mathrm{KCl}$ & Cloreto de potássio \\
\hline $\mathrm{kDa}$ & KiloDalton \\
\hline ITS & Internal transcribed spacer \\
\hline $\mathrm{L}$ & Litro \\
\hline $\mathrm{LC}_{50}$ & Concentração letal para $50 \%$ \\
\hline LC-MS & Cromatografia Líquida acoplada a Espectrometria de Massas \\
\hline M & Concentração molar \\
\hline MET & Miscroscopia eletrônica de trânsmissão \\
\hline MEV & Miscroscopia eletrônica de varredura \\
\hline $\mathrm{MgCl}_{2}$ & Cloreto de magnásio \\
\hline $\mathrm{mg}$ & Miligrama \\
\hline $\mathrm{mL}$ & Mililitro \\
\hline $\mathrm{mm}$ & Milímetro \\
\hline $\mathrm{mM}$ & Milimol \\
\hline MTT & Brometo de [3-(4,5-dimetiltiazol-2-il)-2,5-difeniltetrazólio] \\
\hline $\mathrm{NaCL}$ & Cloreto de sódio \\
\hline NCBI & National Center for Biotechnology Information \\
\hline ng & Nanograma \\
\hline $\mathrm{nm}$ & Nanometro \\
\hline $\mathrm{nM}$ & Nanomol \\
\hline NP & Nanopartícula(s) \\
\hline NP Ag & Nanopartícula(s) de prata \\
\hline PAGE & Polyacrilamide gel electrophoresis \\
\hline
\end{tabular}


PCR Polimerase Chain Reaction

PD Potato dextrose liquid medium

pH Potencial Hidrogeniônico

ppm Partes por milhão

PVP Polivinil pirrolidona

rpm Rotações por minuto

ROS Espécies reativas de oxigênio

RPMI 1640 Roswell Park Memorial Institute medium

rRNA Ribosomal ribonucleic acid

SDS Sodium dodecyl sulfate

TBE Tris/Borate/EDTA

Tris-HCl Trishydroxymethylaminomethane-hydrochloride

UFC Unidades formadoras de colônia

$\mathrm{v} / \mathrm{v} \quad \%$ volume por volume 


\section{LISTA DE ILUSTRAÇÕES}

Figura 1 - Perfil de absorbâncias de NP Ag obtidas a partir dos FF de L-2-2, R-2BI-4, MGE201, MGE-202 e R-3BI-10 na região de 250 a 650 nm 96 horas após adição de nitrato de prata. 46

Figura 2 - Medidas de absorbâncias a $440 \mathrm{~nm}$ das dispersões de NP Ag obtidas a partir do FF de L-2-2, R-2BI-4, MGE-201, MGE-202 e R-3BI-10 no período de 0 a 96 horas. 47

Figura 3 - (A) Filtrado fúngico obtido a partir da cultura do fungo MGE-201, e (B) dispersão de NP Ag obtidas a partir do FF de MGE-201. Observação da cor marrom 24 horas após a adição de nitrato de prata para concentração final de $1 \mathrm{mM}$ 47

Figura 4 - Microscopia Eletrônica de Transmissão (MET) das dispersões de NP Ag de (A) L2-2, (B) MGE-201 e (C) R-2BI-4. Ampliações de 100 nm.

Figura 5 - Imagens dos elementos relevantes encontrados na amostra de MGE-201, usando elétrons monocromáticos correspondentes a enxofre L 2,3. Fenda de seleção de energia fixada em $367 \pm 6 \mathrm{keV}$ para prata e $165 \pm 6 \mathrm{eV}$ para enxofre. A análise por ESI mostra a presença de: a) NP Ag, b), c) enxofre e d) nitrogênio....

Figura 6 - SDS-PAGE $12 \%$ e $10 \%$ para análise das proteínas presentes no FF e aderidas as NP de L-2-2 e MGE-201, usando padrão de massa molecular de 10 a 260 $\mathrm{kDa}$. 54

Figura 7 - Espectros de emissão de fluorescência para NP Ag de L-2-2 e MGE-201 $\left(\lambda_{\text {exc }}=\right.$ 280

$\mathrm{nm})$. 56

Figura 8 - Espectros de emissão de fluorescência para NP Ag de L-2-2 e MGE-201 $\left(\lambda_{\text {exc }}=\right.$ 280

$\mathrm{nm})$.

Figura 9 - Espectros de Infra-vermelho (FTIR) para NP Ag de MGE-201 .......................... 58

Figura 10 - Espectros de Infra-vermelho (FTIR) para NP Ag de L-2-2 ............................. 58

Figura 11 - Atividade antibacteriana de NP Ag de L-2-2 em diferentes concentrações contra $M$. luteus, $P . \quad$ aeruginosa, $S . \quad$ aureus e coli. 62

Figura 12 - Atividade antibacteriana de NP Ag de MGE-201 em diferentes concentrações contra $M . \quad$ luteus, $P . \quad$ aeruginosa, $S$. aureus e $E$. coli. 63

Figura 13 - Microscopia Eletrônica de Varredura de tecido de algodão. Controle não impregnado com nanopartículas (A) e (B) e tecido de algodão impregnado com NP Ag de MGE-201

por $\quad 1 \mathrm{X}$

(C)

$\mathrm{e}$ (D). 
Figura 14 - Microscopia Eletrônica de Varredura de tecido de algodão controle não impregnada com nanopartículas (A) e de tecido de algodão impregnado com NP Ag de L-2-2 $\begin{array}{lllllll}\text { por } & 1 \mathrm{X} & \text { (B) } & \mathrm{e} & \text { (C) } & \mathrm{e} & 4 \mathrm{x}\end{array}$ (D)

Figura 15 - Microscopia Eletrônica de Varredura de tecido de poliéster controle não impregnado (A) e (B), e de tecido de poliéster impregnado com NP Ag de MGE-201 por 1X
(C)
$\mathrm{e}$
$4 \mathrm{X}$
(D)
$\mathrm{e}$
$4 \mathrm{x}$

(D).

66

Figura 16 - Microscopia Eletrônica de Varredura de tecido de poliéster. Controle não impregnado com nanopartículas (A) e (B), e de tecido de poliéster
com
NP
$\mathrm{Ag} \quad \mathrm{de}$
L-2-2 por
$1 \mathrm{X}$
(C)

impregnado

(D)

Figura 17 - Viabilidade celular de macrófagos tratados com nanopartículas de prata de L-2-2 e MGE-201 nas concentrações de 8 a $1.000 \mu \mathrm{g} / \mathrm{mL}$ pelos ensaios de DNA e MTT. A concentração $\underline{0}$ (zero) refere-se a macrófagos tratados somente com meio de cultura DMEM. Média de dois ensaios independentes. 71

Figura 18 - Viabilidade celular de hepatócitos de ratos tratados com nanopartículas de prata de L-2-2 e MGE-201 nas concentrações de 8 a $1.000 \mu \mathrm{g} / \mathrm{mL}$ pelos ensaios de DNA e MTT. A concentração $\underline{0}$ (zero) refere-se a hepatócitos tratados somente com meio de cultura DMEM. Média de dois ensaios independentes 72 


\section{LISTA DE TABELAS}

Tabela 1 - Resultados das medidas de Índice de Polidispersão, Tamanho Médio, Potencial Zeta e Resposta do Programa para Tamanho Médio e Potencial Zeta de NP Ag obtidas a partir de 14 linhagens de fungos testadas

Tabela 2 - Identificação molecular dos isolados de fungos codificados como L-2-2 e MGE201.

Tabela 3 - Proteínas identificadas no filtrado fúngico de MGE-201 e respectivos microrganismos 55

Tabela 4 - Porcentagem de incorporação das NP Ag preparadas a partir dos fungos L-2-2 e MGE-201 nos tecidos de algodão e poliéster.

Tabela 5 - Concentrações Inibitórias Mínimas (CIMs), em $\mu \mathrm{g} / \mathrm{mL}(\mu \mathrm{M})$, de NP Ag preparadas a partir dos FF de L-2-2 e MGE-201 contra espécies Candida sp 60

Tabela 6 - Concentrações Inibitórias Mínimas (CIMs) em $\mu \mathrm{M}$ de nanopartículas de prata sintetizadas a partir dos filtrados fúngicos de L-2-2 e MGE-201 contra E. coli, S.aureus, $P$. aeruginosa e $M$, luteus.

Tabela 7 - Ação antifúngica de tecidos de algodão e poliéster impregnados com NP Ag de L2-2 e MGE-201 por 1x, 2x e 4x sobre $C$. albicans IOC 3704/ATCC 36802. 68

Tabela 8 - Ação antifúngica contra $C$. albicans de tecidos de algodão e poliéster impregnados com NP Ag obtidas a partir da cultura dos fungos L-2-2 e MGE-201

Tabela 9 - Ação antibacteriana dos tecidos de poliéster e de algodão impregnados com as NP Ag de L-2-2 e MGE-201 sobre cepas clínicas de E. coli e $S$. aureus.

Tabela 10 - Viabilidade celular $\left(\mathrm{IC}_{50}\right)$ de macrófagos $\mathrm{J} 774$ e hepatócitos de ratos tratados com as nanopartículas de prata de L-2-2 e MGE-201..... 


\section{SUMÁRIO}

1 INTRODUÇÃO

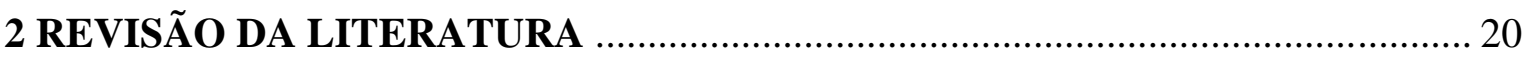

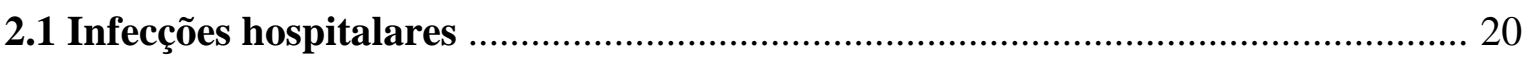

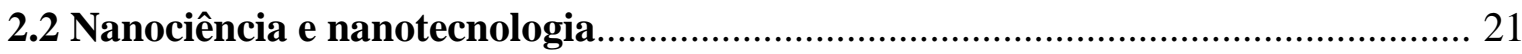

2.3 Síntese de nanopartículas................................................................................ 24

2.4 Mangue

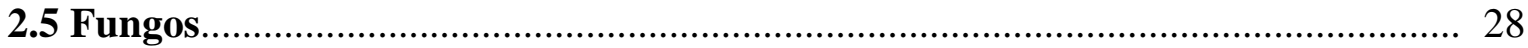

2.6 Toxicidade de nanopartículas de prata............................................................ 28

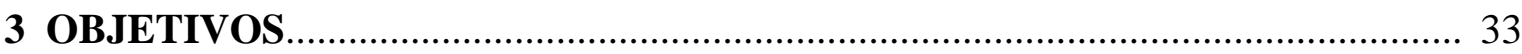

4 MATERIAL E MÉTODOS............................................................................. 34

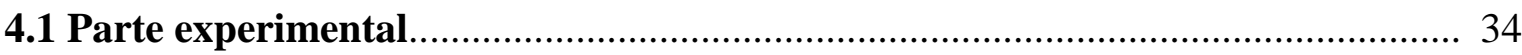

4.1.1 Linhagens de fungos...................................................................................... 35

4.1.2 Identificação taxonômica dos fungos por análises moleculares.................................. 36

4.1.3 Obtenção das nanopartículas de prata.................................................................. 37

4.1.4 Caracterização físico-química das nanopartículas...................................................... 38

4.1.5 Teste de ação antimicrobiana das nanopartículas de prata - determinação

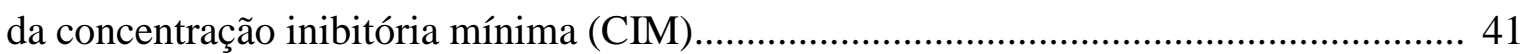

4.1.6 Impregnação de NP Ag em tecidos de algodão e poliéster pelo método

Padding......................................................................................................... 42

4.1.7 Avaliação da porcentagem de incorporação das NP Ag nos tecidos de algodão e poliéster.

4.1.8 Microscopia Eletrônica de Varredura (MEV) dos tecidos impregnados com

NP Ag 43

4.1.9 Avaliação da ação antimicrobiana......................................................................... 43

4.2 Avaliação da toxicidade das nanopartículas de prata em macrófagos e

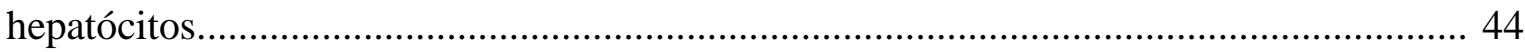

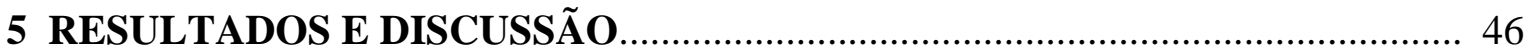

5.1 Síntese e caracterização físico-química das NP Ag.............................................. 46

5.2 Identificação taxonômica dos isolados fúngicos....................................................... 52

5.3 Análise das proteínas aderidas as nanopartículas por SDS-

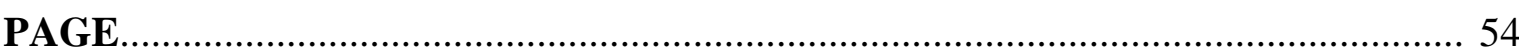

5.4 Análise de proteínas por Cromatografia Líquida acoplada a 


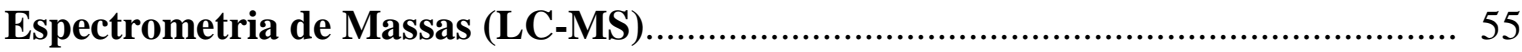

5.5 Análise de proteínas por emissão de fluorescência............................................... 55

5.6 Análise de proteínas por espectroscopia de infravermelho próximo (FTIR)

5.7 Avaliação da porcentagem de incorporação das np ag nos tecidos de algodão e poliéster.

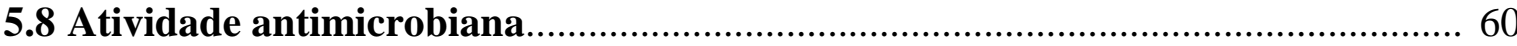

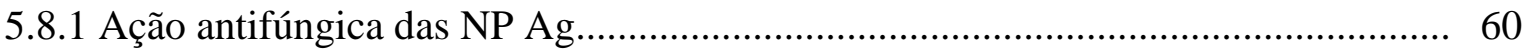

5.8.2 Ação Antibacteriana das NP Ag.................................................................... 61

5.9 Microscopia eletrônica de varredura dos tecidos de algodão e poliéster

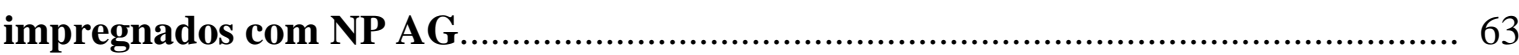

5.10 Ação antifúngica de tecidos impregnados com NP AG .....................................68

5.11 TESTE DE AÇÃO ANTIBACTERIANA PARA TECIDOS IMPREGNADOS

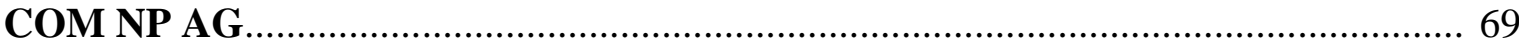

5.12 ESTUDO DA TOXICIDADE DAS NANOPARTÍCULAS DE PRATA............ 70

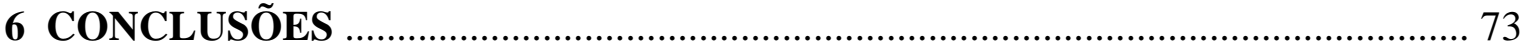

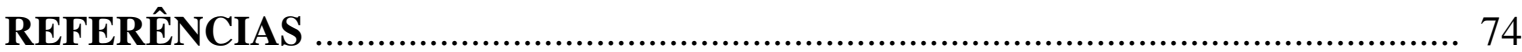

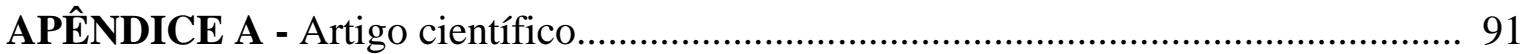

ANEXO A - Análise de proteínas presentes no FF e dispersão de NP Ag obtidas a partir do fungo MGE-201 por Cromatografia Líquida acoplada a Espectrometria de Massas (LC-MS)

ANEXO B - Árvores fenéticas construídas a partir dos fungos L-2-2, MGE-201 e R-2BI-4 


\section{INTRODUÇÃO}

As infecções hospitalares constituem um problema de saúde pública em países não desenvolvidos, com perda da qualidade de vida do paciente, e um custo adicional no procedimento hospitalar que pode variar de US\$ 146,00 a 131.276,00 (FUKUDA et al., 2011). No Brasil, estima-se que o número de óbitos causados por infecções hospitalares seja de 45.000 casos por ano (MALUCHE et al., 2008). Considerando a gravidade e consequências das infecções hospitalares, e a prevenção como ponto crucial para o melhor controle da mesma, o uso de vestimentas hospitalares e emprego de materiais médicos que proporcionem a eliminação ou redução da presença de microrganismos e, consequentemente, maior proteção ao paciente, tem sido uma alternativa estudada (BAKER et al., 2005; DURÁN et al., 2007; LUOMA, 2008; RAI et al., 2009).

Nanopartículas inorgânicas têm um papel importante em diferentes áreas, como na eletrônica e medicina, onde têm sido empregadas com grande sucesso (FARIA et al., 2010; PRABHUA et al., 2013). Dentre estas nanopartículas, as de prata possuem propriedades antimicrobianas relevantes e são usadas na preparação de materiais detentores de ação antimicrobiana, como produtos de higiene pessoal, eletrodomésticos, vestimentas e materiais de uso médico (JAIN; PRADEEP, 2005; KOKURA et al., 2010; LUBICK, 2008; PRABHUA et al., 2013). Devido aos inconvenientes decorrentes dos métodos físicos e químicos na síntese de nanopartículas de prata (NP Ag), pelo uso de reagentes tóxicos e possível contaminação ambiental, há grande interesse no uso de métodos biológicos com a aplicação de microrganismos (ARYA et al., 2010; DURÁN et al., 2007).

Nesse projeto, quatorze linhagens de fungos isolados de manguezais do estado de São Paulo foram avaliadas quanto a capacidade de síntese de NP Ag. Duas linhagens codificadas como L-2-2 e MGE-201 foram selecionadas para continuidade do estudo e foram identificadas taxonomicamente. A formação de nanopartículas foi monitorada pela presença da banda de ressonância plasmônica em espectrofotômetro a $440 \mathrm{~nm}$ e a caracterização foi realizada por técnicas físico-químicas como Microscopia Eletrônica de Transmissão e Espectroscopia de Correlação de Fótons. Para complementar o estudo, a análise de proteínas aderidas às NP Ag foi realizada por Cromatografia Líquida acoplada a Espectrometria de Massas (LC-MS), Emissão de Fluorescência e Espectroscopia de Infra-Vermelho Próximo (FIRT). 
A ação antimicrobiana das NP Ag em dispersão, e impregnadas em tecidos de algodão e poliéster, foi avaliada em espécies de Candida sp, assim como em bactérias Gram-negativas e Gram-positivas frequentemente presentes em infecções hospitalares.

Tecidos de algodão e de poliéster foram impregnados com as NP Ag de L-2-2 e MGE201 e avaliados em relação a sua ação antifúngica em C. albicans ATCC 36802, C. glabrata IOC 4565 e C. parapsilosis IOC 4564 e ação antibacteriana em E. coli, S. aureus, $P$. aeruginosa e M. luteus. 


\section{REVISÃO DA LITERATURA}

\subsection{Infecções hospitalares}

As infecções hospitalares ocorrem pela penetração e/ou multiplicação de um agente infeccioso ou seu produto tóxico no organismo humano em ambiente hospitalar (BRASIL, 1977). De acordo com a Organização Mundial da Saúde (OMS), as infecções hospitalares constituem um problema de saúde pública em países não desenvolvidos, com perda da qualidade de vida do paciente, além de incorrer em um custo adicional no procedimento hospitalar que pode variar de US\$ 146,00 a 131.276,00, de acordo com o estado de saúde do paciente, órgão afetado, severidade da infecção e complicações que dela surgirem (BREATHNACH et al., 2005; FUKUDA et al., 2011; WORLD HEALTH ORGANIZATION, 2002). No Brasil, Maluche et al. (2008) estimam que o número de óbitos causados por infecções hospitalares seja de 45.000 casos por ano. Em um estudo Rulka, Lima e Neves (2012), analisaram 91 publicações científicas sobre infecção hospitalar no Brasil nos últimos 35 anos, e concluíram que as bactérias constituem $32 \%$ dos agentes etiológicos. Pereira et al. (2010), relataram os aspectos clínicos e epidemiológicos de 50 pacientes vítimas de candidemia durante um período de cinco anos (2004-2008), em um hospital público da cidade de São Paulo. Os autores constataram que 32\% das infecções ocorreram em crianças menores de 12 anos, sendo a unidade de Hematologia e Transplante de Medula Óssea o local com maior número das ocorrências (31\%). O total de óbitos na unidade foi de $51 \%$.

As causas dessas infecções podem ser tanto endógenas (quando o agente infeccioso é proveniente do próprio paciente) quanto exógena (quando o agente infeccioso provém do ambiente hospitalar). Portanto, as medidas de prevenção de infecções hospitalares, como a assepsia da pele do paciente e a manutenção de um ambiente hospitalar limpo, devem ser adotadas com rigor pelos dirigentes de hospitais e profissionais da área de saúde, e que os profissionais sigam as determinações das Comissões de Controle de Infecção Hospitalar (CCIHs), para que o risco seja minimizado (MACHADO et al., 2001; RULKA; LIMA; NEVES, 2012; WORLD HEALTH ORGANIZATION, 2002).

Considerando a gravidade e consequências das infecções hospitalares, e a prevenção como ponto crucial para o melhor controle da mesma, o uso de vestimentas hospitalares e emprego de materiais médicos que proporcionem a eliminação, ou a redução da presença de microrganismos e consequentemente, maior proteção ao paciente, tem sido uma alternativa 
avaliada em diversos estudos (BAKER et al., 2005; DURÁN et al., 2007; LUOMA, 2008; RAI et al., 2009).

A prata $\left(\mathrm{Ag}^{+}\right)$é um metal pesado monovalente, branco e o maior condutor elétrico entre os metais. Apresenta ação antimicrobiana de amplo espectro e limitada toxicidade em humanos. A atividade antimicrobiana da prata ocorre pela interação com grupos orgânicos tióis presentes em proteínas e paredes celulares, também por indução da formação de espécies reativas de oxigênio (WHITE; COOPER, 2005; LUOMA, 2008). O uso de solução de nitrato de prata na prevenção de infecção ocular foi descrito há mais de um século, sendo usada até a introdução dos antibióticos na Segunda Guerra Mundial (EISLER, 1996; LUOMA, 2008; SILVER, 2003). Mesmo após a introdução das sulfas e antibióticos o uso da prata associada à sulfonamidas para o tratamento de queimaduras ainda é adotado em hospitais, incorporada em pomadas e creme hidrofílicos, aplicada como proteção em catéteres, amálgamas, implantes, e processos de purificação de água (GATTER; KOHNEN; JANSEN, 1998; KLASEN, 2000; SILVER, 2003; LUOMA, 2008; WHITE; COOPER, 2005). Na forma de nanopartículas, a prata tem sua ação potencializada, pois há maior reatividade devido ao aumento da superfície de contato (LUOMA, 2008; TOMA et al., 2005).

\subsection{Nanopartículas de prata (NP Ag)}

A nanotecnologia estuda as propriedades, desenvolvimento e aplicações de materiais em escala nanométrica, proporcionando novas possibilidades de aplicações a materiais já existentes e consequentemente influenciando a economia, a medicina e a indústria (JORDAN; KAISER; MOORE, 2012; PRESCHITSCHEK; DOMINIC, 2010). O investimento em nanotecnologia tem sido cada vez maior durante as últimas décadas, e na área científica algumas de suas possíveis aplicações já haviam sido previstas a mais de um século (FEYNMAN, 1960; PUURUNEN; VASARA, 2007; SARGENT JR., 2012).

Países como Estados Unidos e China têm adotado programas prioritários para o financiamento de estudos em nanotecnologia, resultando em aumento do número de patentes nessa área nos últimos anos (JORDAN; KAISER; MOORE, 2012; MICHELSON, 2008). Outros países como Japão, Alemanha, França, Reino Unido e Coréia do Sul, também tem seguido esta linha de investimentos. No entanto, a participação brasileira de patentes em nanotecnologia não tem sido substancial (JORDAN; KAISER; MOORE, 2012; NIOSI; REID, 2007; YING; LU; PORTER, 2010), como tem ocorrido em outros países (ANDERSEN, 2011; IPO, 2009; PRESCHITSCHEK; DOMINIC, 2010). 
Nanopartículas metálicas têm entre 1-100 nm e propriedades químicas e físicas diferentes daquelas que apresentam seus respectivos materiais em maior escala, resultando em comportamentos magnético, elétrico e óptico únicos (LUOMA, 2008; TOMA et al., 2005). O entendimento e controle destas características permite a obtenção de materiais mais adequados para diversos fins (CUENYA, 2010). Metais como ferro, cobre, ouro, titânio e prata têm sido usados para a obtenção de nanopartículas (CHEN et al., 2013; DISCH et al., 2013; GARCÍA et al., 2013; LEE; SONG; KIM., 2013; RODRIGUES et al., 2013).

Nanopartículas de prata têm inúmeras aplicações. Dentre elas pode-se citar o uso em: dispositivos de máquinas na indústria alimentícia (JIANG et al., 2004), espumas de poliuretano utilizadas em purificadores de água (JAIN; PRADEEP, 2005; LUBICK, 2008), indústria do papel (PUURUNEN; VASARA, 2007), tratamento de águas residuais (CHOI et al., 2008), materiais de uso odontológico (ACOSTA-TORRES et al., 2011), produtos cosméticos (KOKURA et al., 2010), medicina (DURÁN et al., 2010; GIBBONS; WARNER, 2005; MONTEIRO et al., 2009; PRABHUA et al., 2013), biorremediação (SELVAKUMAR et al., 2011), catalisadores (EDSON et al., 2012; ZHANG et al., 2011), controle de biofilme (ZHANG et al., 2012), indústria eletrônica (FARIA et al., 2012), energia solar (GREEN; PILLAI, 2012) e mais recentemente no desenvolvimento de métodos espectrofotométricos e colorimétricos para detecção de ácido ascórbico (YANG et al., 2012), polifenóis (ÖZYÜREK et al., 2012) e DNA (CROUSE et al., 2012; LIU; ZHANG; HAN; 2005).

Um fenômeno característico da formação de nanopartículas de prata é a presença da banda plasmônica de superfície - também denominada de ressonância localizada de plasmon de superfície (LSPR) - a qual representa oscilações coletivas de elétrons de condução, resultantes de ressonâncias ópticas em nanopartículas de metais nobres, envolvendo o confinamento quântico e a constante dielétrica dos materiais (EVANOFF JR; CHUMANOV, 2005; KREIBIG; VOLLMER, 1995; PETRYAYEVA; KRULL, 2011; VALDEN; LAI; GOODMAN, 1998). Quando excitadas por luz, as cargas induzidas na superfície dos metais podem se propagar como uma onda eletromagnética, criando um campo elétrico intenso (WILEY et al., 2006). O controle do espalhamento e absorção da luz foi demonstrado por Wiley et al. (2006). Os autores sintetizaram e compararam nanopartículas de prata de diversos formatos usando etilenoglicol como solvente e agente redutor, as quais apresentaram bandas de plasmon com picos entre 400 e $600 \mathrm{~nm}$, de acordo com sua forma geométrica.

A largura da banda de plasmon é diretamente proporcional ao aumento do tamanho da partícula, exceto para partículas menores que $10 \mathrm{~nm}$, cujo aumento da banda é inversamente proporcional ao tamanho das partículas (HEATH, 1989; KREIBIG; SCHMITZ; BREUER, 
1987). Além disso, partículas menores mudam a coloração do meio, tornando-o mais avermelhado (LIU et al., 1998) ou esverdeado (EVANOFF JR; CHUMANOV, 2005). A forma das partículas também influencia suas propriedades, o comprimento de emissão de luz (EVANOFF JR; CHUMANOV, 2005; JANA; GEARHEART; MURPHY, 2001; PETRYAYEVA; KRULL, 2011). No caso dos nanofluidos, a reologia e a condutividade elétrica das nanopartículas são importantes, pois melhoram a viscosidade e condutividade, de acordo com a temperatura aplicada (GOHARSHADI; AZIZI-TOUPKANLOO, 2012).

Michael Faraday foi o primeiro a demonstrar que quando em suspensão coloidal, o tamanho da partícula tem influencia direta na cor, em 1857 (FARADAY, 1857). Posteriormente, o físico alemão Gustav Mie, então professor na Universidade de Greifswald, publicou um importante trabalho no qual abordava o espalhamento da luz por pequenas partículas esféricas, baseado na teoria de Maxwell, no qual a constante dielétrica do meio e da partícula foram os parâmetros considerados (MIE, 1908). Ludvig Lorenz, matemático dinamarquês, e Peter Debye, físico holandês, também contribuíram no fundamento dessa teoria que é usada até hoje no estudo das partículas e em outros campos da ciência, como na astronomia (LORENZ, 1898; DEBYE, 1909). Estes trabalhos foram importantes para o entendimento dos efeitos ópticos das nanopartículas (EVANOFF JR; CHUMANOV, 2005; KERKER, 1969). Explorando essa propriedade, e com o objetivo de obter maior estabilidade de polivinil álcool (PVA) - material que pode ser empregado na produção de telas de cristais líquidos (LCD) - Agabekov et al. (2012), descreveram o melhoramento das propriedades ópticas e a resistência à umidade deste polímero modificado com nanopartículas de prata.

A catálise química tem grande importância industrial e econômica (CUENYA, 2010) e a capacidade catalítica das nanopartículas tem sido descrita por mais de uma década (HARUTA, 1997; VALDEN; LAI; GOODMAN, 1998) e está relacionada ao diâmetro e a espessura dessas partículas, o que têm sido objeto de discussão (CUENYA, 2010). A espessura, assim como sua estrutura (ordenadas em esfera ou dispostas em bicamada, formando um filme) são parâmetros mais críticos que o diâmetro, e são importantes no rendimento da reação (CHEN; GOODMAN, 2006). A função das nanopartículas na melhora da atividade catalítica de óxidos metálicos tem sido objeto de estudo devido a sua influência nas interações óxido-metal (HERZING et al., 2008), e no estado de oxidação (CUENYA, 2010), sendo a distância interpartícula importante com relação a estabilidade do sistema, pois, partículas muito próximas poderiam se aglomerar com mais facilidade (ONO; ROLDÁNCUENYA, 2007; PRIETO et al., 2012). 


\subsection{Síntese de nanopartículas}

A síntese de nanopartículas de prata pode ser realizada por métodos físicos e químicos. Um dos principais métodos para a síntese de nanopartículas consiste na redução e estabilização das nanopartículas pelo íon citrato (TURKEVITCH et al., 1951). Para que estas se mantenham estáveis e desagregadas na dispersão, a presença de uma camada estabilizante que evite a aglomeração é essencial, seja por repulsão eletrostática ou por impedimento estérico. Grupos orgânicos poliméricos frequentemente são empregados nessa etapa, (KHAN et al., 2011). A agregação de nanopartículas é facilmente reconhecida pelo deslocamento da banda de plasmon para regiões de menor energia de elétrons de superfície - sendo que a energia de transição eletrônica depende da densidade de estados eletrônicos e do tamanho das nanopartículas (TOMA et al., 2005).

A redução por citrato foi uma das primeiras abordagens para a síntese de nanopartículas de prata e apesar de continuar sendo utilizada, a demanda por maior estabilidade induziu a busca por alternativas, já que este método é sensível a variação de $\mathrm{pH}$, força iônica do meio e a presença de materiais orgânicos.

Outro método químico comum para a redução da prata é o método de Brust-Schiffrin (Brust et al., 1994), em que boroidreto de sódio é usado como agente redutor, como exemplificado na seguinte reação:

$$
\mathrm{AgNO}_{3}+\mathrm{NaBH}_{4} \rightarrow \mathrm{Ag}+1 / 2 \mathrm{H}_{2}+1 / 2 \mathrm{~B}_{2} \mathrm{H}_{6}+\mathrm{NaNO}_{3}
$$

A síntese por este método, usando boroidreto de sódio como agente redutor e brometo de amônio como agente estabilizante, foi modificada e grupos tióis têm sido empregados em substituição ao brometo de amônio, para aumentar a estabilidade da dispersão. O aperfeiçoamento do método, como o controle sobre o tamanho e dispersão das partículas, síntese sem uso de solventes orgânicos e métodos mais ecológicos têm sido investigados, visto que a utilização de grupos tióis apresentam limitações, tais como a necessidade de reagentes compatíveis com o estabilizante (AHAMED et al., 2003; CHEN; MURRAY, 2000; DAHL; MADUXX; HUTCHISON, 2007; EKLUND; CLIFFEL, 2004).

A síntese de nanopartículas por métodos físicos tem sido realizada por energia térmica (GASPAR et al., 2013; SUN; LUO, 2005), fotorredução (BALAN et al., 2012) e irradiação de microondas (RENUGADEVI; ASWINI, 2012). Além destes, outros métodos têm sido empregados como a deposição a vácuo, ablação a laser, sol-gel, co-precipitação, impregnação, 
deposição a vapor e a eletrodeposição (KRUTYAKOV et al., 2008; KABASHIN et al., 2010; PETRYAYEVA; KRULL, 2011).

Diversos métodos para a síntese de NP Ag, assim como para a impregnação de tecidos de algodão com essas nanopartículas têm sido descritos (ANTONY et al., 2011; DURÁN et al., 2007; DURÁN et al., 2010; RAI et al., 2009; RAVINDRA et al., 2010). No entanto, esses processos tem como desvantagem o alto consumo de energia e uso de reagentes tóxicos, que elevam os custos de produção e podem contaminar o meio ambiente (DURÁN et al., 2007; DURÁN et al., 2010; EL-NOUR et al., 2010; LUOMA, 2008; ZHANG et al., 2011). Nesse contexto, a obtenção de nanopartículas de prata mediada por microrganismos tem sido estudada por ser ambientalmente favorável e economicamente mais vantajosa (ARYA et al., 2010; GULRAJANI et al., 2007). Sondi e Salopek-Sondi (2004) descreveram o acúmulo de Ag NP na membrana de E. coli. Além disso, Morones et al. (2005) mostraram evidências da adsorção e acúmulo de Ag NP em células de bactérias Gram negativas (E. coli, V. cholera, P. aeruginosa e S. typhus). Antony et al. (2011) demonstraram que nanopartículas de prata obtidas por método biológico apresentaram atividade antibacteriana sobre espécies Gram positivas (Bacillus cereus e S. aureus) e Gram negativas (E. coli, Klebsiella pneumoniae, Proteus mirabilis, $P$. aeruginosa e Salmonella typhii) mais eficaz do que aquelas obtidas por método químico, destacando a importância da abordagem biológica.

A obtenção de NP Ag por método biológico também tem sido desenvolvida com o uso de plantas (SATHISHKUMAR et al., 2010), algas (MERIN et al., 2010), bactérias (SINTUBIN et al., 2009), leveduras (KOWSHIK et al., 2003) e fungos (DURÁN et al., 2005). Entretanto o uso de fungos e bactérias pode ser de maior interesse quando comparado a outras fontes, pela existência de uma tecnologia já disponível (ZHANG et al., 2011).

Dentre os microrganismos explorados para a síntese de nanopartículas de prata, os fungos proporcionam algumas vantagens, como: (a) facilidade de cultura em larga escala, (b) o processo e a manipulação da biomassa podem ser simples, (c) o processo pode ser estendido para síntese de nanopartículas de diferentes composições químicas, formas e tamanhos, (d) viabilidade econômica, e (e) resistência do micélio a pressão de fluxo e agitação em biorreatores (quando comparado a plantas e bactérias) (GADE et al., 2008; NARAYANAN et al., 2010).

Diversos trabalhos têm demonstrado a importância dos fungos na obtenção de NP Ag. Ahmad et al. (2003) relataram a síntese extracelular de NP Ag mediada por Fusarium oxysporum. Os autores atribuíram a formação de NP Ag à ação de enzimas redutases e a mudança de coloração do meio reagente, de amarelo para marrom-escuro à excitação do 
plasmon de superfície. Nesse trabalho, observou-se absorbância na região de $270 \mathrm{~nm}$, indicativo da presença de proteínas na solução. Durán et al. (2005) usando esta mesma espécie de fungo também sugeriram a participação de enzimas redutases e antraquinonas na obtenção de NP Ag.

Em trabalhos posteriores, os fungos Aspergillus fumigatus (BHAINSA et al., 2006), Phaenerochaete chrysosporium (WIGNESHWARAN et al., 2006), A. flavus (WIGNESHWARAN et al., 2007) e F. oxysporum (DURÁN et al., 2007) foram usados para a síntese de NP Ag, sendo que neste último a impregnação de NP em tecidos de algodão e o efeito antibacteriano deste tecido sobre $S$. aureus foram descritos.

Gade et al. (2008) demonstraram atividade antibacteriana de NP Ag obtidas a partir do fungo A. niger. Outros estudos foram publicados usando os fungos Cladiosporium cladiospoioides (BALAJI et al., 2009), Alternaria alternata (GAJBHIYE et al., 2009), Penicillinum fellutanum (KATHIRESAN et al., 2009), P. brevicompactum (SHALIGRAM et al., 2009), F. solani (EL-RAFIE et al., 2010), A. niger (KATHIRESAN et al., 2010), Geotricum sp. (JEBALI et al., 2011), Neurospora crassa (SALUNKHE et al., 2011) e Cochliobulos lunatus (CASTRO-LONGORIA et al., 2011).

Embora grande número de publicações relate a obtenção de nanopartículas de prata com o emprego de microrganismos, especialmente fungos. Foi somente em 2009 que o primeiro estudo empregando a espécie do fungo P. fellutanum, isolado de manguezal, na síntese de nanopartículas de prata foi publicado (KATHIRESAN et al., 2009). No Brasil, poucos são os estudos com o emprego de microrganismos de manguezais e as pesquisas estão concentradas na busca de metabólitos biologicamente ativos (SEBASTIANES et al., 2012; SILVA et al., 2011) e de diversidade microbiológica (CLEARY et al., 2012; COSTA; MAIA; CAVALCANTI, 2012; DIAS et al., 2010; DOURADO et al.; 2012; MENDES et al., 2012; PEIXOTO et al., 2011). Considerando os dados já publicados, nosso estudo também é pioneiro na abordagem do potencial da aplicação biotecnológica de fungos isolados de manguezais na síntese de nanopartículas de prata.

\subsection{Mangue}

Os manguezais são ecossistemas de transição entre os ambientes terrestre e marinho, e local de encontro de água doce e salgada, onde proliferam plantas características dos habitats palustres, como as avicênias, rizóforas e lagunculárias (KATHIRESAN; BINGHAM, 2001). 
São ecossistemas sujeitos a inundação periódica, localizados em áreas litorâneas tropicais e subtropicais, sendo importantes fontes de nutrientes para várias espécies animais (GAYATHRI et al., 2010). O solo do mangue é pobre em oxigênio e rico em matéria orgânica, a qual é decomposta e disponibilizada para organismos autotróficos e heterotróficos, e os fungos são importantes decompositores desse material, processando uma grande quantidade de biomassa (SCHAEFFER-NOVELLI, 1995).

O mangue apresenta alta variação do teor de salinidade e a inconstância das marés afeta a concentração de oxigênio, fazendo deste um ambiente propício à diversidade microbiológica (ANDREOTE et al., 2012; FERREIRA et al., 2010; HOLGUIN et al., 2001; KATHIRESAN; BINGHAM, 2001). Este ecossistema é importante no controle da erosão e eficiente sequestrador de carbono, sendo estimado que $14 \%$ do carbono total sejam captados pelos mangues por ano, sendo assim o ecossistema que mais sequestra carbono por área, com alta produtividade e concentração de biomassa (ALONGI, 2012; KOMIYAMA et al., 2008). A vegetação presente nos mangues compreende o mangue vermelho (Rizophora mangle); o mangue branco (Laguncularia racemosa) e o mangue preto (Avicennia spp) (MARTINS et al., 2011). A fauna do manguezal é composta por espécies residentes e visitantes e, embora com baixa diversidade, existe grande quantidade de animais, dentre eles os mais comuns são os crustáceos (caranguejos, siris e camarões) e os moluscos (ostras, sururus e caramujos) (DELABIE et al., 2006).

O mangue tem sido explorado como fonte de novas moléculas obtidas de extratos de plantas com a finalidade de uso medicinal. Em decorrência das características ambientais estes extratos têm apresentado atividade antimicrobiana contra patógenos importantes na clínica médica (SHELAR et al., 2012). Muitas novas espécies de fungos e bactérias já foram isoladas de manguezais da Índia, Mar Vermelho, Indonésia, Estados Unidos, Austrália, e outros países (ANANDA et al., 2004; HOLGUIN et al., 2001).

No Brasil, alguns estudos têm sido realizados para avaliar a comunidade microbiana presente no mangue brasileiro (ANDREOTE et al., 2012), assim como a diversidade de cianobactérias (RIGONATO et al., 2013). Além disso, interações entre a fauna e a flora (DA LUZ; BARTH, 2012), o impacto causado ao mangue devido à atividade humana (VIEIRA et al., 2013) e as condições climáticas no mangue (DE LIMA; GILMA; GALVANI, 2013) também tem sido avaliados. 


\subsection{Fungos}

Os fungos são microrganismos eucariotos, não fotossintetizantes, que exercem papeis importantes no meio ambiente, como a biodegradação de material orgânico para obtenção de nutrientes. A parede celular dos fungos é composta por quitina e possui ergosterol, ao invés de colesterol presente em células mamíferas. Diferente das bactérias e actinomicetos, as células de fungos têm núcleo e podem apresentar-se na forma de leveduras (unicelular), ou na forma filamentosa (multicelular), formados por hifas, que quando agregadas formam o micélio. Algumas hifas podem apresentar-se na forma de células multinucleadas e indivisíveis, enquanto outras podem ser septadas, com segmentos facilmente distinguíveis. Alguns fungos desenvolvem uma relação simbiótica com algas filamentosas ou cianobactérias na forma de liquens (HANSON, 2008).

Os fungos não crescem isoladamente e a relação com plantas, insetos e mamíferos pode ser positiva, quando há uma relação simbiótica com o hospedeiro, como as micorrizas (associações entre fungos e raízes), facilitando a recaptação de nutrientes pela planta. Por outro lado, algumas espécies são patogênicas para plantas e o homem (HANSON, 2008; LI et al., 2013; MAYFIELD et al., 2012).

Os fungos associados a plantas podem ser classificados como epifíticos ou endofíticos. Os epifíticos são aqueles que habitam a superfície das plantas, e os endolíticos são aqueles que habitam o interior das plantas como as raízes, caules ou folhas, emergindo para esporular (OSONO, 2008; RODRIGUEZ et al., 2009). Como descrito anteriormente, diversas espécies de fungos já foram usadas no estudo de síntese de nanopartículas de prata como as espécies de F. oxysporum, A. fumigatus, $C$. cladiospoioides, e a isolada de mangue $P$. fellutanum. Neste estudo empregamos espécies de fungos isoladas de mangues do estado de São Paulo para avaliar o potencial de síntese de nanopartículas de prata por microrganismos isolados deste ecossistema.

\subsection{Toxicidade das nanopartículas de prata}

Como já mencionado, nanopartículas de prata têm grande potencial de uso, e seu rápido desenvolvimento tem causado preocupação em relação à toxicidade que materiais nanoestruturados podem causar quando em contato com seres vivos e/ou liberados no meio ambiente. A maior proporção de área por volume poderia facilitar a toxicidade já que a penetração da prata seria favorecida na forma de nanopartículas do que na sua forma iônica. 
Além disso, com o maior uso de prata pode haver consequências ambientais se houver liberação desta no meio ambiente (LUOMA, 2008). Portanto, são necessários estudos para melhor conhecimento do risco que estes materiais podem representar aos seres humanos e ao meio ambiente (LUOMA, 2008; PANYALA; PEÑA-MÉNDEZ; HAVEL, 2008).

Alt et al. (2004) investigaram a toxicidade in vitro de polimetilmetacrilato (PMMA), (um biopolímero usado em próteses) impregnado com NP Ag na concentração de 1\%, em fibroblastos de camundongo (ensaio quantitativo) e osteoblastos humanos (ensaio qualitativo). Os autores não encontraram diferenças significativas de citotoxicidade do biomaterial quando em contato com as células teste. No entanto, para confirmar os resultados estudos in vivo devem ser realizados.

Ahamed et al. (2008) estudaram a toxicidade de NP Ag em DNA de células-tronco embrionárias e fibroblastos embrionários de camundongos. As NP Ag testadas com e sem uma cobertura polissacarídica, induzindo morte celular mesmo pós $72 \mathrm{~h}$ de tratamento. As NP Ag funcionalizadas com o polissacarídeo foram mais tóxicas que as NP não funcionalizadas em ambos os tipos de células testadas e causaram diferentes danos às células.

A diminuição dos níveis de glutationa e dano ao DNA, por ação de nanopartículas, com aumento de espécies reativas de oxigênio, têm sido descritas por diferentes autores (ARORA et al., 2008; ASHARANI et al., 2009). Kim et al. (2009b) relataram o acometimento de células hepáticas em uma paciente intoxicada com prata após ingestão de prata coloidal por 16 meses a uma concentração elevada $(381 \mathrm{ng} / \mathrm{mL})$, resultando em um caso de argiria (condição causada por ingestão do metal) com modificações na cor da pele. Outros estudos têm descrito dano dose dependente ao DNA com o uso de NP Ag em diferentes células e animais. No entanto, os resultados não podem ser devidamente comparados devido a distintos e importantes parâmetros utilizados, como por exemplo, tamanhos das NP e influência da molécula estabilizante (DE LIMA; SEABRAC; DURÁN, 2012; FOLDBJERG; DANG; AUTRUP; 2011).

Em outro trabalho Hackenberg et al. (2011) avaliaram o dano causado por NP Ag ao DNA de células-tronco mesenquimais derivadas de tecido adiposo. Estas células foram escolhidas por estarem em contato direto com áreas que seriam regeneradas em implantes. $\mathrm{O}$ dano celular foi avaliado pelo teste de exclusão do azul de tripan e pelo teste de fluorescência de diacetato após 1, 3 e 24 horas de exposição. Os efeitos citotóxicos das nanopartículas foram observados na concentração de $10 \mu \mathrm{g} / \mathrm{mL}$ e o dano ao DNA na concentração de 0,1 $\mu \mathrm{g} / \mathrm{mL}$, em todos os períodos de exposição. 
A toxicidade de NP Ag em linhagem celular derivada de macrófagos foi avaliada por Park et al. (2010). O estudo mostrou morte celular causada por possível apoptose, com aumento na secreção de óxido nítrico, interferon gama e expressão de metaloproteinases, e diminuição do nível de glutationa, corroborando informações prévias (ARORA et al., 2008; PARK et al., 2010). Já Lankveld et al. (2010) descreveram a cinética de distribuição de NP Ag nos tamanhos de 20, 80 e $110 \mathrm{~nm}$, em diferentes tecidos de camundongos após cinco dias de tratamento diário por administração intravenosa. As nanopartículas com $20 \mathrm{~nm}$ de tamanho foram encontradas principalmente no fígado, rins e baço, enquanto nanopartículas maiores estavam presentes no baço, fígado e pulmões.

A toxicidade subcrônica oral de NP Ag em ratos foi avaliada por Kim et al. (2010) por um período de 90 dias com doses de 30, 125 e $500 \mathrm{mg} / \mathrm{kg}$. Dano hepático foi observado nos animais tratados com NP Ag a partir de $125 \mathrm{mg} / \mathrm{kg}$. Também foi observada hiperplasia no ducto biliar e acúmulo dose dependente de prata em todos os tecidos tratados, numa concentração duas vezes maior nos rins de fêmeas. Os autores propõem que o órgão alvo nesse caso foi o fígado, tanto nos machos quanto nas fêmeas, sendo que a concentração mais baixa testada (30 mg/Kg de NP Ag) não induziu efeitos adversos. Sulaiman et al. (2013) avaliaram a ação de NP Ag obtidas a partir de folhas de Eucalyptus chapmaniana em linhagens leucêmicas humanas HL-60. Os autores demonstraram que as NP Ag têm ação dose e tempo dependente, com viabilidade celular de apenas $15 \%$ após 24 horas a 0,02 mM, demonstrando o potencial das NP Ag para tratamento de células tumorais. Ainda avaliando a ação das NP Ag em células tumorais, pelo ensaio do MTT em células de câncer cervical (HeLa), nanopartículas obtidas a partir do extrato de folhas de Podophyllum hexandrum induziram dano ao DNA e morte celular mediada por caspase, proteína envolvida no processo de apoptose Jeyaraj et al. (2013).

Em um estudo para avaliar a possível toxicidade de NP Ag no tratamento de canais dentários Gomes-filho et al. (2010) analisaram a resposta de tecido conjuntivo de ratos a tubos contendo fibrina embebidos em dispersão de NP Ag em comparação com solução de hipoclorito de sódio a 2,5\%. Os animais foram expostos aos tubos de polietileno contendo esponjas embebidas em 23 e 47 ppm de nanopartículas de prata por 90 dias. Ambas as concentrações apresentaram reação moderada em 7 dias de exposição. A dispersão de nanopartículas mostrou-se biocompatível, especialmente quando testada na concentração mais baixa.

Kaegi et al. (2010) estudaram a liberação de NP Ag no meio ambiente por um período de um ano. Os autores usaram tinta contento NP Ag sobre as paredes de uma casa e 
analisaram a liberação de nanopartículas em amostras coletadas após as chuvas. Cerca de 30\% das NP foram encontradas na água escoada da chuva após o contato com a cobertura contendo nanopartículas, no entanto é provável que as nanopartículas tenham se transformado em formas menos tóxicas, como sulfeto de prata $\left(\mathrm{Ag}_{2} \mathrm{~S}\right)$, após reação da prata com ácido sulfídrico $\left(\mathrm{H}_{2} \mathrm{~S}\right)$ atmosférico. Em um trabalho de revisão Fabrega et al. (2011) abordaram o comportamento e os efeitos tóxicos de NP Ag em algas, animais invertebrados, microrganismos, peixes e a bioacumulação de NP Ag no meio ambiente aquático. Os poucos trabalhos publicados abordando a toxicidade de NP Ag no crescimento de algas não indicaram efeitos comprometedores em concentrações previstas de serem encontradas em seus habitats (MIAO et al., 2009; NAVARRO et al., 2008b), mas em um estudo com a alga C. reinhardtii o efeito tóxico das NP foi maior do que íons de prata devido a interação da nanopartícula com a célula da alga (NAVARRO et al., 2008b). Em relação aos invertebrados, os autores destacam a importância de se considerar os reagentes envolvidos da obtenção das NP, força iônica e concentração da fonte de carbono, já que estes também podem influenciar na toxicidade (KVITEK et al., 2009).

Um trabalho publicado em 2008 (CHOI; HU, 2008) atribui a toxicidade de NP Ag em microrganismos ao tamanho e a forma das nanopartículas. Entretanto outros estudos sugerem a dissolução de prata na forma iônica das NP como responsável pelo efeito bactericida (NAVARRO et al., 2008b), assim como acúmulo de espécies reativas de oxigênio (ROS) intracelular na bactéria (CHOI; HU, 2008) e a força eletrostática contribuindo para a adesão das nanopartículas à superfície da célula bacteriana (JIANG et al., 2009). Os autores ainda citam as variações fisiológicas, anatômicas e de comportamento entre as cepas bacterianas, diferentes tamanhos de NP usadas e diversos métodos de obtenção destas, como parâmetros que dificultam uma interpretação mais consistente sobre a toxicidade de NP Ag quando o objetivo é investigar o modo de ação das mesmas, com resultados por vezes contraditórios (KIM et al., 2007; RUPARELIA et al., 2008; YOON et al., 2007).

Em peixes foram encontrados valores de $\mathrm{LC}_{50}$ (concentração letal para $50 \%$ dos animais em experimento) de 0,8 $\mu \mathrm{g} / \mathrm{L}$ para algumas espécies (BIRGE; ZUIDERVEEN, 1995). Os íons de prata podem alcançar as células epiteliais dos brônquios, afetando a regulação iônica por meio das guelras e, em concentrações milimolares, causar consequências fisiológicas importantes, como acidose, podendo levar a morte (GROSELL et al., 1999). As NP Ag com tamanho entre 10-80 nm parecem afetar o estágio de desenvolvimento inicial de vida dos peixes, incluindo deformidades no cordão espinhal e arritmia cardíaca (ASHARANI et al., 2008). Assim como prata iônica, NP Ag podem se acumular nas guelras e no fígado, 
causando estresse oxidativo (BILBERG et al., 2010). Contudo, o período em que tais eventos ocorrem varia de acordo com os experimentos e espécies analisadas. Ainda alguns estudos têm demonstrado que pode haver recaptação diferenciada de prata quando em solução e nanoparticulada, variando também os tecidos em que a prata pode ser acumulada (ASHARANI et al., 2008; YEO; YOON, 2009). Bilberg et al. (2012) descreveram a toxicidade de NP Ag recobertas com polivinil pirrolidona (PVP) em zebrafish por 48 horas comparada com a toxicidade causada por íons de prata. As concentrações letais $\left(\mathrm{LC}_{50}\right)$ encontradas foram de 25 e de $84 \mu \mathrm{g} / \mathrm{L}$ para prata iônica e nanoparticulada, respectivamente. $\mathrm{O}$ estudo também revelou toxicidade respiratória causada por nanopartículas e íons de prata, demonstrando que NP Ag são letais para zebrafish.

Poucos estudos têm comparado à toxicidade de nanopartículas biogênica e química (DE LIMA; SEABRAC; DURÁN, 2012) e uma investigação adequada dos efeitos desses materiais no ser humano e no meio ambiente pode evitar que uma tecnologia promissora cause inconvenientes no futuro. 


\section{OBJETIVOS}

O objetivo principal deste trabalho foi avaliar o potencial de linhagens de fungos isolados de manguezais do Estado de São Paulo na síntese de nanopartículas de prata e impregnação das mesmas em tecidos de algodão e poliéster. Para esta finalidade os objetivos específicos foram:

$\checkmark$ Comparar o desempenho de 14 linhagens de fungos isolados de mangue em relação à capacidade de síntese de nanopartículas de prata e seleção das duas linhagens mais efetivas no processo;

$\checkmark$ Caracterização físico-química das nanopartículas de prata por medida do diâmetro médio, índice de polidispersão, potencial zeta e morfologia;

$\checkmark$ Determinar a concentração e a massa molecular das proteínas aderidas às nanopartículas de prata;

$\checkmark \quad$ Impregnar e caracterizar a adesão das nanopartículas de prata em tecidos de algodão e de poliéster;

$\checkmark$ Avaliar a atividade antimicrobiana das nanopartículas de prata livres e dos tecidos impregnados contra diferentes espécies de patógenos presentes em infecções hospitalares. 


\section{MATERIAL E MÉTODOS}

Para o desenvolvimento do estudo as linhagens de fungos provenientes de manguezais foram gentilmente cedidas pelo Prof. Itamar Soares de Melo do Laboratório de Microbiologia Ambiental da Embrapa Meio Ambiente, Jaguariúna, São Paulo. A caracterização físicoquímica das nanopartículas de prata foi realizada com a colaboração da Prof ${ }^{\mathrm{a}}$. Dra. Ljubica Tasic do Instituto de Química da UNICAMP (IQ/UNICAMP) e da Prof ${ }^{\mathrm{a}}$. Dra. Priscyla D. Marcato da Faculdade de Ciências Framacêuticas de Ribeirão Preto/Universidade de São Paulo (FCFRP/USP). As análises de proteínas por LC-MS foram feitas com o auxílio do Prof. Dr. Fábio C. Gozzo também do IQ-UNICAMP, e os experimentos de atividade antibacteriana com a colaboração da Dra. Rita C. Ruiz do laboratório de Bacteriologia do Instituto Butantan.

\subsection{Parte experimental}

Neste trabalho foram usados:

Água destilada estéril

Álcool Etílico - (Sigma-Aldrich, St. Louis, MO, Estados Unidos)

Álcool isoamílico - (LABSYNTH Produtos para laboratórios LTDA, Diadema, SP, Brasil)

Anfotericina - (Cultilab, Campinas, SP, Brasil)

Comassie (Bradford) Protein Assay Kit - (Thermo Fisher Scientific, Waltham, Massachusetts, Estados Unidos)

Brometo de [3-(4,5-dimetiltiazol-2-il)-2,5-difeniltetrazólio] (MTT) - (Sigma-Aldrich, St. Louis, MO, Estados Unidos)

BSA - (Thermo Fisher Scientific, Waltham, Massachusetts, Estados Unidos)

DMEM - (Cultilab, Campinas, Brasil)dNTP _ (Fermentas, Vilnius, Lituânia)

EDTA - (Sigma-Aldrich, St. Louis, MO, Estados Unidos)

Enzima tripsina - Sequencing Grade Modified Trypsin - marca Promega Tris-HCl (Sigma-Aldrich, St. Louis, MO, Estados Unidos)

Fenol - (Sigma-Aldrich, St. Louis, MO, Estados Unidos)

Cloreto de Potássio - $\mathrm{KCl}$ - (LABSYNTH Produtos para laboratórios LTDA, Diadema, SP, Brasil)

Cloreto de sódio - NaCl - (Fluka, Buchs, Suiça)

Nitrato de prata - (MERCK, Rio de Janeiro, RJ, Brasil) 
Marcador de peso molecular de proteína 10-260 kDa (Fermentas, Vilnius, Lituânia)

Meio de cultura batata dextrose ágar - (HIMEDIA código M096, Mumbai, MA, Índia)

Meio de cultura batata dextrose - (HIMEDIA código M403, Mumbai, MA, Índia)

$\mathrm{MgCl}_{2-}$ (Fermentas, Vilnius, Lituânia)

Primers ITS1 e ITS4 - (Sigma-Aldrich, St. Louis, MO, Estados Unidos)

Rezazurin - (Acros organics, New Jersey, Estados Unidos)

RPMI 1640 - (Vitrocell, Campinas, SP, Brasil)

SDS - (Sigma-Aldrich, St. Louis, MO, Estados Unidos)

Taq DNA polimerase - Prime Taq ${ }^{\mathrm{TM}}$ DNA polymerase - (Genet Bio, Yuseong-gu, Daejeon, Coréia do Sul)

Tetraciclina - (Sigma-Aldrich, St. Louis, MO, Estados Unidos)

Tetracloreto de carbono - CCl4 - (LABSYNTH Produtos para laboratórios LTDA, Diadema, SP, Brasil)

\subsubsection{Linhagens de fungos}

Neste estudo foram utilizadas quatorze linhagens de fungos (A-1-8, A-3BI-11, A-3BI17, L-2-2, L-3BI-15, MGE-182, MGE-201, MGE-202, R-2BI-4, R-2BI-6, R-2BI-8, R-2BI-9, R-2BI-13 e R-3BI-10) isolados de manguezais das cidades de Cananéia e de Bertioga no estado de São Paulo a partir das espécies de plantas de Rhizophora mangle (mangue vermelho), Avicennia ssp (mangue preto) e Laguncularia racemosa (mangue branco).

Os fungos epifíticos foram isolados da superfície de tecidos vegetais (folhas, caules e raízes) pela técnica da lavagem com água estéril (GOMES et al., 2005) e os endofíticos foram isolados pela técnica de desinfecção superficial (ARAÚJO et al., 2001). Para obtenção dos fungos epifíticos, as folhas das plantas foram rapidamente lavadas por imersão em água destilada estéril, e em seguida fragmentos de $5 \mathrm{~mm}$ foram incubados em meio batata dextrose ágar. Após o crescimento, as colônias foram sendo sucessivamente transferidas para nova placa de petri com meio batata dextrose ágar (BDA) até total isolamento das linhagens.

Para isolamento de fungos endofíticos, folhas de plantas saudáveis foram sequencialmente imersas em solução de etanol a 70\% durante 1 minuto, em solução de hipoclorito de sódio a $2,5 \%$ durante 4 minutos, e finalmente em etanol a $70 \%$ durante 1 minuto. Em seguida, as folhas foram imersas sequencialmente por três vezes em água destilada estéril. Fragmentos no tamanho de $5 \mathrm{~mm}$ foram incubados em placa de petri contendo meio BDA com $100 \mu \mathrm{g} / \mathrm{mL}$ de tetraciclina e, em seguida as placas foram incubadas 
durante 7 dias a $28{ }^{\circ} \mathrm{C}$. Colônias de fungos que cresceram a partir dos fragmentos foram então sendo sucessivamente transferidas para nova placa com meio BDA até completo isolamento das linhagens, as quais foram conservadas em meio BDA, pelo método de Castellani e também a $-80^{\circ} \mathrm{C}$ (CASTELLANI, 1967).

\subsubsection{Identificação taxonômica dos fungos por análises moleculares}

Para a identificação, os fungos codificados como L-2-2, MGE-201 e R-2BI-4 foram cultivados em meio $\mathrm{BD}$ a $28{ }^{\circ} \mathrm{C}$ por pelo menos uma semana e o micélio formado foi liofilizado para total remoção de resíduos de água. A biomassa foi cuidadosamente macerada e empregada para a extração do DNA genômico a $4{ }^{\circ} \mathrm{C}$.

O método de extração do DNA genômico foi adaptado de Raeder e Broda (1985) e González-Mendoza et al. (2010). Para cada fungo, em um tubo tipo eppendorf com capacidade para $2 \mathrm{~mL}$, a $20 \mathrm{mg}$ de micélio macerado foram adicionados $200 \mu \mathrm{L}$ de tampão de extração (SDS 3\%; EDTA 0,5 mM; $\mathrm{NaCl} 1 \mathrm{M}$ e Tris-HCl 0,1 mM a pH 8,0) e a mistura foi homogeneizada em agitador de tubos Sarstedt (Nümbrecht-Rommelsdorf, Alemanha) por 15 segundos. Em seguida, $200 \mu \mathrm{L}$ de uma solução de clorofórmio:fenol:álcool isoamílico $(25: 24: 1 \mathrm{v} / \mathrm{v} / \mathrm{v})$ foram adicionados lentamente a cada mistura e os tubos foram incubados em banho-maria UltraSonic Cleaner 1450 (Unique, Indaiatuba, SP, Brasil) a $65^{\circ} \mathrm{C}$ por 5 minutos.

A mistura foi resfriada e centrifugada em centrífuga Eppendorf 5810R (Hamburgo, Alemanha) a $10.000 \mathrm{~g} \mathrm{e} \mathrm{a} 4{ }^{\circ} \mathrm{C}$ por 10 minutos. Após a centrifugação, o sobrenadante foi transferido para outro tubo e o mesmo volume de etanol absoluto gelado foi adicionado ao tubo. A mistura foi agitada vigorosamente e incubada a $-20{ }^{\circ} \mathrm{C}$ por 20 minutos para precipitação total de DNA. Após nova centrifugação, o sobrenadante foi descartado e $1 \mathrm{~mL}$ de etanol a 75\% foi adicionado ao DNA precipitado. Após repetição desta última etapa e descarte do sobrenadante, o DNA precipitado foi solubilizado com $50 \mu \mathrm{L}$ de água deionizada estéril e armazenado a $-20{ }^{\circ} \mathrm{C}$ até o momento do uso.

Para amplificação da região ITS do rDNA foram utilizados os primers ITS1 (5' CCCGCCGCGCGCGGCGGGCGGGGC 3') e ITS4 (5'TCCTCCGCTTATTGATATGC 3'). A Reação em Cadeia da Polimerase (PCR) (Sigma-Aldrich, St. Louis, MO, Estados Unidos) foi realizada utilizando-se $25 \mu \mathrm{L}$ de uma solução contendo: $20 \mathrm{ng}$ de DNA, $\mathrm{MgCl}_{2} 1,5 \mathrm{nM}$, dNTP 0,2 mM, tampão da reação 1x, ITS1 $0.5 \mu \mathrm{M}$, ITS4 0,5 $\mu \mathrm{M}$ e Taq DNA polimerase $1 \mathrm{U}$ (Prime Taq ${ }^{\mathrm{TM}}$ DNA polymerase Genet Bio, Yuseong-gu, Daejeon, Coréia do Sul). As reações de PCR foram realizadas em um termociclador Mastercycler gradient machine (Eppendorf, 
Hamburgo, Alemanha). A programação consistiu de uma desnaturação inicial a $95{ }^{\circ} \mathrm{C}$ por 1 minuto, seguida por 30 ciclos de 30 segundos de desnaturação a $94{ }^{\circ} \mathrm{C}, 30$ segundos de anelamento a temperatura específica para cada amostra e 1 minuto de extensão a $72{ }^{\circ} \mathrm{C}$. Os produtos de PCR foram analisados por eletroforese em gel de agarose a 1\%, em tampão TBE 0,5 X durante aproximadamente 90 minutos a $80 \mathrm{~V}$ e purificados usando o kit GeneJET ${ }^{\mathrm{TM}}$ Gel Extraction (Fermentas, Vilnius, Lituânia).

As amostras (produto de PCR purificado + primer) foram sequenciadas no sequenciador ABI 3730 DNA Analyser (PE Applied Biosystems, Carlsbad, CA, USA). As sequências obtidas de $28 \mathrm{~S}$ rDNA foram comparadas com as depositadas no GenBank através do eBLASTn, disponível no portal NCBI (http://www.ncbi.nlm.nih.gov/blast/) e CBS (http:// www.cbs.knaw.nl/). As sequencias foram alinhadas usando o programa CLUSTAL X (THOMPSON et al. 1994) e analisadas com software MEGA versão 4.0 (TAMURA et al., 2007). As distâncias matrizes evolucionárias foram calculadas usando o modelo de Kimura (1980), e a construção da árvore fenética das distancias evolucionárias foi feita usando o algoritmo de junção de vizinhos (SAITOU; NEI, 1987), com valores de bootstrap calculados de 1.000 replicatas.

\subsubsection{Obtenção das nanopartículas de prata}

As linhagens de fungos codificadas como A-1-8, A-3BI-11, A-3BI-17, L-2-2, L-3BI-15, MGE-182, MGE-201, MGE-202, R-2BI-4, R-2BI-6, R-2BI-8, R-2BI-9, R-2BI-13 e R-3BI-10 inicialmente cultivadas em meio BDA em placas de Petri a $28{ }^{\circ} \mathrm{C}$ foram transferidas para 150 $\mathrm{mL}$ de meio líquido BD e incubadas em incubador Marconi (Piracicapa, SP, Brasil) a $28^{\circ} \mathrm{C}$, e $150 \mathrm{rpm}$ por 72 horas. Após esse período, sob condição estéril, a biomassa foi filtrada em membrana de algodão, lavada com água destilada estéril para remoção dos resíduos do meio de cultura e novamente incubada com água destilada estéril a $25^{\circ} \mathrm{C}$ e $150 \mathrm{rpm}$ por 72 horas na proporção de $10 \mathrm{~g} / 100 \mathrm{~mL}$ de água estéril.

Após a incubação, a biomassa foi removida por filtração e ao sobrenadante filtrado em membrana estéril de $0,22 \mu \mathrm{m}$ - filtrado fúngico (FF) - foi adicionada uma solução de nitrato de prata, em quantidade adequada para atingir uma concentração final de $1 \mathrm{mM}$. A mistura reacional foi mantida sob proteção da luz e a redução da prata, resultando em formação das nanopartículas foi monitorada com espectrofotômetro Agilent 8453 (Santa Clara, CA, Estados Unidos) por 96 horas a $440 \mathrm{~nm}$, visto que NP Ag formam uma banda de ressonância de Plasmon nessa região (DURÁN et al., 2005.; MOORES; GOETTMANN, 2006). 


\subsubsection{Caracterização físico-química das nanopartículas}

Análise morfológica

Após a síntese, as NP Ag foram caracterizadas por análise da morfologia por Microscopia Eletrônica de Transmissão (TEM) e análise do tamanho médio e medida do potencial zeta pela técnica de Espectroscopia de Correlação de Fótons. Para complementar o estudo, a análise de proteínas aderidas às NP Ag L-2-2 e MGE-201 foi realizada por Cromatografia Líquida acoplada a Espectrometria de Massas (LC-MS), Emissão de Fluorescência e Espectroscopia de Infra-Vermelho Próximo (FIRT).

Microscopia Eletrônica de Transmissão (TEM) das NP

A morfologia das NP Ag foi observada por Microscopia Eletrônica de Transmissão (TEM). As imagens de TEM foram realizadas em um microscópio Carl Zeiss CEM-902 (Oberkochen, Alemanha) de $80 \mathrm{KeV}$, com as partículas depositadas em um porta-amostra de cobre recoberto com filme de parlódio. As imagens elementares foram obtidas para os elementos relevantes encontrados na amostra, usando elétrons monocromáticos correspondentes a enxofre L 2,3. A fenda de seleção de energia foi fixada em $367 \pm 6 \mathrm{keV}$ para prata e $165 \pm 6 \mathrm{eV}$ para enxofre.

Tamanho médio, distribuição de tamanho das NP e potencial zeta

O diâmetro médio das NP Ag de L-2-2 e MGE-201, assim como a distribuição do tamanho e a carga superficial (potencial zeta) foram determinados pela técnica de Espectroscopia de Correlação de Fótons utilizando analisador de tamanho NanoSizer (Malvern Instruments Corp, Worcestershire, UK). As medidas foram realizadas em duplicata por dispersão das nanopartículas em solução de $\mathrm{KCl}$ a 1 mM 1:1 (v/v).

Determinação da concentração e massa molecular das proteínas presentes no filtrado fúngico e presentes na dispersão de nanopartículas de prata

Para a determinação da concentração de proteínas ao FF e a dispersão de NP Ag foram adicionados sulfato de amônio com $80 \%$ de saturação até a precipitação das proteínas. A suspensão resultante foi centrifugada e o precipitado obtido foi dissolvido em tampão fosfato $(0,05 \mathrm{M}, \mathrm{pH} 8,0)$. A concentração de proteínas foi determinada de acordo com o 
método descrito por Lowry et al. (1951) usando soroalbumina bovina (BSA) (Thermo Fisher Scientific, Waltham, Massachusetts, Estados Unidos) como padrão.

Para determinação da massa molecular, os concentrados de proteínas obtidos do FF e das NP Ag foram dializados a $4{ }^{\circ} \mathrm{C}$, em tampão fosfato $(0,05 \mathrm{M})$ por 24 horas para remoção do sal. As amostras foram aplicadas em eletroforese em gel de poliacrilamida - dodecil sulfato de sódio (SDS-PAGE) a 10\% e 12\%, e para comparação e determinação das massas moleculares foi utilizado um padrão marcador de massa molecular de 10-260 kDa (Fermentas, Vilnius, Lituânia).

Análise de proteínas por Cromatografia Líquida acoplada a Espectrometria de Massas (LCMS)

Os experimentos foram realizados em cromatógrafo nanoAcquity UPLC (Waters, Milford, Massachusetts, Estados Unidos) acoplado a espectrômetro Synapt HDMS (Waters), com 13 geometria QTOF, equipado com fonte de nanoESI (ionização eletrospray) operando no modo de aquisição dependente de dados (DDA).

As proteínas foram analisadas por LC-MS por desnaturação da amostra seguida de digestão tríptica utilizando a dessalinização e concentração (http://www.promega.com/ /media/Files/Resources/Protocols/Product\%20Information\%20Sh eets/N/Sequencing\%20Grade\%20Modified\%20Trypsin\%20Protocol.ashx). A $50 \mu \mathrm{L}$ de extrato de proteínas foram adicionados $150 \mu \mathrm{L}$ de solução aquosa contendo uréia $(8 \mathrm{M})$, Tris.HCl (100 mM pH 7,6) e ditiotreitrol (DTT, $10 \mathrm{mM}$ ), e então a mistura foi aquecida a 95 ${ }^{\circ} \mathrm{C}$ por 20 minutos sob agitação branda para desnaturação das proteínas. A seguir, a solução foi resfriada a temperatura ambiente, e diluída 10x (concentração final de uréia $<1 \mathrm{M}$ ) em tampão bicarbonato de amônio (100 mM, pH 7,8). Foi então adicionada uma solução de tripsina em ácido acético $50 \mathrm{mM}$ (substrato/enzima), seguido de agitação branda por 18 horas a $37{ }^{\circ} \mathrm{C}$. A seguir, as soluções foram dessalinizadas em cartuchos de extração em fase sólida (SPE) Oasis HLB (Waters, Milford, Massachusetts, Estados Unidos), com capacidade de 1 cc/30 mg, mediante condicionamento do cartucho [ $1 \mathrm{~mL}$ acetonitrila com $0,1 \%$ ácido fórmico (v/v)], seguido de $1 \mathrm{~mL}$ de água contendo $0,1 \%$ ácido fórmico (v/v), carregamento da amostra, dessalinização com $1 \mathrm{~mL}$ de água (0,1\% ácido fórmico v/v) e eluição dos peptídeos com $1 \mathrm{~mL}$ de acetonitrila $(0,1 \%$ ácido fórmico $\mathrm{v} / \mathrm{v})$. A cada solução resultante foram adicionados $50 \mu \mathrm{L}$ de água e as mesmas foram então concentradas até cerca de $50 \mu \mathrm{L}$ em concentrador SpeedVac Savant SPD131DDA (Thermo Fisher Scientific, Waltham, 
Massachusetts, Estados Unidos). As soluções resultantes foram centrifugadas (10 min a $17.000 \times \mathrm{g}$ ) e o sobrenadante transferido para vials apropriados para análise por LC-MS/MS. As amostras aquosas foram então injetadas no sistema UPLC e direcionados a uma pré-coluna (Waters Symmetry $\mathrm{C}_{18}, 20 \mathrm{~mm} \times 180 \mu \mathrm{m}$ d.i., partículas de $5 \mu \mathrm{m}$ ), onde foram dessalinizadas por 3 minutos com fluxo de 5,0 $\mu \mathrm{L} / \mathrm{min}$ com fase móvel de 3\% de B (fases móveis A: $\mathrm{H}_{2} \mathrm{O}$ /ácido fórmico $0,1 \%$; B: acetonitrila/ácido fórmico $0,1 \%$ ), sendo então transferidas para a coluna analítica (Waters BEH130 $\mathrm{C}_{18}, 100 \mathrm{~mm} \times 100 \mu \mathrm{m}$ i.d., partículas de 1,7 $\mu \mathrm{m}$ ) e eluídas com fluxo de $1,0 \mu \mathrm{L} / \mathrm{min}$ com gradiente. No tempo zero a fase móvel foi de $97 \%$ de A e $3 \%$ de B. Na sequencia a fase móvel B foi de 3 a 30\% em 40 min, de 30 a $80 \%$ em 10 min e mantida por $10 \mathrm{~min}$, de 80 a $3 \%$ em 1 min, e mantida por mais 4 min.

A detecção dos peptídeos foi realizada por sistema online composto por espectrômetro de massas, configurado para operar em modo de aquisição dependente de dados (DDA) contendo uma função de MS fullscan ( $\mathrm{m} / z, 200$ a 2.000), três funções de espectro de íons fragmentos (MS/MS, $\mathrm{m} / z 50$ até 50 unidades acima da $\mathrm{m} / \mathrm{z}$ do precursor) e uma função de padrão externo de calibração (lockmass, $\mathrm{m} / z 200$ a 2.000). Todos os espectros foram adquiridos a uma taxa de $1 \mathrm{~Hz}$. Os critérios para escolha de íons precursores para experimentos de espectro de íons fragmentos foram: a) o estado de carga do precursor, sendo eleitos apenas precursores em estados de carga $+2,+3,+4,+5$; b) a intensidade, sendo descartados íons com intensidade inferior a 20 contagens. As energias de colisão aplicadas nos experimentos de espectro de íons fragmentos foram definidas como perfis individuais (curvas de energia de colisão versus $\mathrm{m} / \mathrm{z}$ do precursor) para cada estado de carga de $+2 \mathrm{a}+5$.

Resumindo as configurações acima, para uma corrida de LC-MS (DDA) típica o instrumento inicia a corrida adquirindo espectros de MS fullscan $(\mathrm{m} / \mathrm{z} 150$ a 2.000) a uma taxa de $1 \mathrm{~Hz}$. Uma vez identificados (em um determinado espectro de MS fullscan), até três íons que cumprem os critérios supracitados para experimentos de espectro de íons fragmentos são selecionados pelo instrumento (por ordem decrescente de intensidade), que adquire um espectro de íons fragmentos para cada um (1 s cada), retornando então ao modo MS fullscan e adquirindo mais um espectro. Como demais parâmetros do espectrômetro de massas estão voltagem do capilar $3,0 \mathrm{kV}$, voltagem do cone $30 \mathrm{~V}$, temperatura da fonte $100{ }^{\circ} \mathrm{C}$, fluxo do gás de nanoESI 0,5 L/h, energias de colisão das celas Trap e Transfer respectivamente em 6 e $4 \mathrm{eV}$ e detector em $1.700 \mathrm{~V}$.

As corridas de LC-MS foram processadas (deconvolução, deisotopização e correção de medida de $\mathrm{m} / \mathrm{z}$ ) pelo software ProteinLynx Global Server v.2.2. (Waters) e analisadas por busca em banco de dados empregando-se o sistema MASCOT v.2.2. (Matrix Science Ltd. 
http://www.matrixscience.com). Como parâmetros da busca foram selecionados digestão com tripsina com até um sítio de clivagem ignorado, oxidação em resíduos de metionina como modificação variável e tolerância de massa de peptídeos e fragmentos ambos em $\pm 0,1 \mathrm{Da}$. As buscas foram feitas no banco de dados NCBInr.

Análise de Proteínas por Emissão de Fluorescência

As medidas de fluorescência dos FF e das NP Ag obtidas a partir dos fungos MGE201 e L-2-2 foram obtidas em espectrofluorímetro Perkin Elmer LS-55 (Waltham, Massachusetts, Estados Unidos) utilizando uma cubeta de quartzo com 1,0 cm de caminho óptico. A excitação da amostra foi feita em $280 \mathrm{~nm}$ com fendas de excitação e emissão de 5,0 e $10 \mathrm{~mm}$, respectivamente e os espectros foram adquiridos no intervalo de 300 a $510 \mathrm{~nm}$.

Análise de proteínas por Espectroscopia de Infra-Vermelho com Transformada de Fourrier (FIRT)

As medidas de FIRT para as nanopartículas de prata de L-2-2 e MGE-201 foram feitas em um equipamento ABB Bomem MB series (Zurique, Suiça) com resolução de 4,0 $\mathrm{cm}^{-1}$ e em um intervalo de 4.000 a $400 \mathrm{~cm}^{-1}$. As análises foram feitas em pastilha de $\mathrm{KBr}$.

4.1.5 Teste de ação antimicrobiana das nanopartículas de prata - determinação da concentração inibitória mínima (CIM)

Os ensaios de ação antimicrobiana foram realizados pelo método de microdiluição em placas para fungos (CLSI, 2002; DE SOUZA et al., 2005; PALOMINO et al., 2002; PANÁČEK et al., 2009) e bactérias (Bulet et al.,1993). Para o ensaio de ação antifúngica as espécies de Candida albicans ATCC 36802, C. albicans IOC 4525, C. albicans IOC 4558, C. krusei IOC 4559, C. glabrata IOC 4565, C. guillermondi IOC 4557, C. parapsilosis IOC 4564 e C. tropicalis IOC 4560, identificadas por método padrão (WARREN; SHADOMY, 1991) foram cultivadas em meio sólido BDA. Para uso nos ensaios a concentração das suspensões preparadas em solução salina foi determinada por leitura da absorbância a $530 \mathrm{~nm}$ e ajustada para $1,5 \times 10^{6}$ unidades formadoras de colônia (UFC/mL) de acordo com curva padrão previamente estabelecida. Em seguida em uma placa de 96 cavidades, $100 \mu \mathrm{L}$ das NP Ag de L-2-2 e de MGE-201 foram diluídos serialmente nas concentrações de 8 a $1.000 \mu \mathrm{M}$ e a cada cavidade da placa foram adicionados $100 \mu \mathrm{L}$ das suspensões de Candida sp. A placa 
foi incubada a $32{ }^{\circ} \mathrm{C}$ e a leitura das CIMs foi efetuada após 24 horas com o corante rezazurin (a 0,02\%), indicador de crescimento microbiano (PALOMINO et al., 2002). A CIM é a concentração na qual há pelo menos $90 \%$ de inibição do crescimento do patógeno e é indicada pela permanência da cor azul nas cavidades da placa. A cor rosa indica crescimento de microrganismos.

A atividade antibacteriana de NP Ag foi monitorada por ensaio de inibição de crescimento em meio líquido realizado em placas de microtitulação, como descrito por Bulet et al (1993). A $90 \mu 1$ de uma suspensão de E. coli, S.aureus, P. aeruginosa e M. luteus em caldo pobre em nutrientes (bacto-triptona $1 \%$ e $\mathrm{NaCl} 0,5 \%$ (w/v) na concentração de $1 \times 10^{5}$ $\mathrm{UFC} / \mathrm{mL}$ foram adicionados $10 \mu \mathrm{l}$ de NP em concentrações de 0,14 a 2,20 $\mu \mathrm{g} / \mathrm{mL}(1,25-20$ $\mathrm{mM}$ ). As placas foram incubadas por 18 horas a $30{ }^{\circ} \mathrm{C}$ e $150 \mathrm{rpm}$ por 18 horas e a leitura da absorbância realizada a $595 \mathrm{~nm}$. A porcentagem de inibição do crescimento foi calculada por comparação com o controle da cultura de bactérias crescidas na presença apenas do meio de cultura. Os controles positivos para fungos foram preparados com Anfotericina B, em concentração inferior a $15 \mu \mathrm{g} / \mathrm{mL}$, e para bactérias com gentamicina, nas concentrações de 8 e $16 \mu \mathrm{g} / \mathrm{mL}$. Os controles negativos foram preparados com suspensões de patógenos não tratados. Os ensaios foram realizados em triplicata e os resultados expressos pela média obtida para cada ensaio.

\subsubsection{Impregnação de NP Ag em tecidos de algodão e poliéster pelo método padding}

Para a impregnação com as NP Ag de L-2-2 e de MGE-201, fragmentos de tecidos de algodão e de poliéster no tamanho de 10 x $10 \mathrm{~cm}$ foram imersos na dispersão coloidal de NP Ag até total umedecimento do tecido e, em seguida foram submetidos a uma compressão entre dois rolos (método padding - com uso de máquina destinada ao preparo de massas - PASTA MACHINE ATLAS 150, Marcato, Padova, Itália), e secos a temperatura ambiente sob proteção da luz por 24 horas (DURÁN et al., 2007; DURÁN et al., 2010). A impregnação dos tecidos foi realizada por uma, duas e quatro vezes e fragmentos de 1x1 cm impregnados foram empregados nos testes de ação antimicrobiana.

4.1.7 Avaliação da porcentagem de incorporação das NP Ag nos tecidos de algodão e poliéster

Para avaliação da porcentagem de incorporação das NP de Ag de L-2-2 e MGE-201, nos tecidos de algodão e poliéster, alíquotas de $2 \mathrm{~mL}$ foram retiradas da dispersão de $\mathrm{NP}$ de 
$\mathrm{Ag}$, antes e após o processo de impregnação para determinação da concentração de prata nestas duas etapas. A concentração de prata foi determinada por espectrometria de emissão por plasma (ICP) Agilent (Santa Clara, CA, Estados Unidos) e comparação com uma curva de calibração com $\mathrm{AgNO}_{3}$, previamente preparada. A porcentagem de incorporação de prata foi calculada pela diferença da concentração de prata antes e após a impregnação dos tecidos.

\subsubsection{Microscopia Eletrônica de Varredura (MEV) dos tecidos impregnados com NP Ag}

A morfologia dos tecidos impregnados com NP Ag foi observada por Microscopia Eletrônica de Varredura (MEV). As imagens de MEV foram realizadas em um microscópio JEOL JSM - T300 (Tóquio, Japão) operando em $20 \mathrm{kV}$ com detectores de elétrons secundários. As amostras foram preparadas usando suporte de alumínio (stubs) revestido com fita dupla face e recoberto com ouro por 100 segundos para torná-las eletricamente condutoras.

\subsubsection{Avaliação da ação antimicrobiana}

a) Teste de ação antifúngica para tecidos de algodão e poliéster impregnados com NP Ag

Para avaliar a atividade antimicrobiana $1 \times 1 \mathrm{~cm}$ dos tecidos de algodão e de poliéster impregnados uma vez foram colocados em tubos de vidro contendo $800 \mu \mathrm{L}$ de água destilada estéril e agitados por 10 minutos em agitador rotatório Labnet 211DS (Edison, New Jersey, Estados Unidos) a $220 \mathrm{rpm}$. Em seguida foram adicionados 2,2 $\mathrm{mL}$ de meio líquido BD e 10 $\mu \mathrm{L}$ de suspensão de C. albicans ATCC 36802, C. glabrata IOC 4565 e C. parapsilosis IOC 4564 a 1,87 x $10^{5} \mathrm{UFC} / \mathrm{mL}$ de acordo com curva padrão previamente estabelecida em nosso laboratório. A mistura foi então mantida incubada a $35{ }^{\circ} \mathrm{C}$ e sob agitação a $220 \mathrm{rpm}$ por 24 horas. Após esse período, uma alíquota de $10 \mu \mathrm{L}$ da suspensão foi serialmente diluída e as diluições incubadas em meio sólido BD a $32^{\circ} \mathrm{C}$. A contagem das UFC $/ \mathrm{mL}$ foi efetuada em até 48 horas após a incubação. Como controles foram empregados culturas dos patógenos sem a presença de tecidos e tecidos livres de NP Ag.

b) Teste de ação antibacteriana para tecidos impregnados com NP Ag

Para o ensaio de ação antibacteriana fragmentos de 1 x $1 \mathrm{~cm}$ dos tecidos de algodão e poliéster impregnados uma vez foram incubados com suspensões de E. coli, S.aureus, P. aeruginosa e M. luteus em caldo pobre em nutrientes na concentração de $1 \times 10^{5} \mathrm{UFC} / \mathrm{mL}$ e 
após incubação por 24 horas as absorbâncias das suspensões foram determinadas a $595 \mathrm{~nm}$. A porcentagem de inibição do crescimento bacteriano foi determinada por comparação com o controle composto por cultura de bactérias livres de tecidos contendo NP Ag.

4.2.0 Avaliação da toxicidade das nanopartículas de prata em macrófagos e hepatócitos

A citotoxicidade em cultura de macrófagos $\mathbf{J 7 7 4}$ foi determinada para as nanopartículas de L-2-2 e MGE-201. A dispersão de NP foi dissolvida em DMSO, filtrada em membrana estéril de 0,22 $\mu$ m e diluída em meio de cultura RPMI 1640 nas concentrações de 8 a $1.000 \mu \mathrm{M}$.

Uma suspensão de macrófagos $\mathrm{J} 774$ cultivados a $37^{\circ} \mathrm{C}$ em meio de cultura RPMI 1640 foi preparada e distribuída em placas de 96 cavidades na concentração de 2,0 × $10^{6}$ células/mL (100 $\mu \mathrm{L} /$ cavidade). As placas foram incubadas em incubador Thermo 3110 (Thermo Fisher Scientific, Waltham, Massachusetts, Estados Unidos) a $37{ }^{\circ} \mathrm{C}$ sob atmosfera de $5 \%$ de $\mathrm{CO}_{2}$ durante 12 horas e em seguida o meio de cultura foi substituído por outro contendo a dispersão em teste. Cavidades controle receberam somente meio RPMI 1640 com DMSO a $2 \%$. As placas foram novamente incubadas a $37^{\circ} \mathrm{C} / 5 \%$ de $\mathrm{CO}_{2}$ e decorridas 20 horas de tratamento das células procedeu-se os ensaios de: redução do brometo de [(3-(4,5dimetiltiazol-2-il)-2,5-difeniltetrazólio] (MTT) e determinação do conteúdo de ácidos nucléicos (DNA).

Estes ensaios foram realizados duas vezes em sextuplicata para cada concentração de nanopartículas. Macrófagos do grupo controle tratados apenas com meio de cultura foram considerados como $100 \%$ viáveis. Os valores de $\mathrm{IC}_{50}$ (concentração na qual pelo menos 50\% das células estão viáveis) foram obtidos por interpolação dos dados do gráfico de porcentagem de viabilidade celular versus as concentrações de nanopartículas.

Para o ensaio de avaliação da hepatotoxicidade, hepatócitos foram obtidos de ratos Wistar machos (200-250 gramas) conforme procedimento anteriormente descrito (COUTINHO et al., 2012). A concentração de hepatócitos foi ajustada para $1 \times 10^{6}$ células $/ \mathrm{mL}$ em meio de cultura DMEM suplementado (sulfato de estreptomicina $50 \mathrm{UI} / \mathrm{mL}$, penicilina 50 $\mu \mathrm{g} / \mathrm{mL}$, albumina bovina $0,2 \%$, insulina humana recombinante $0,1 \mathrm{UI} / \mathrm{mL}$, dexametasona $1 \mathrm{M}$, dimetilsulfóxido a $1 \%$ e $10 \%$ de soro fetal bovino) e as células foram distribuídas na proporção de $100 \mu \mathrm{L} /$ cavidade, em placas de 96 cavidades. Após incubação por 3-4 horas a $37{ }^{\circ} \mathrm{C} / 5 \% \mathrm{CO}_{2}$, o meio de cultura foi substituído por outro contendo as NP Ag de L-2-2 e de MGE-201 nas concentrações de 8 a $1.000 \mu \mathrm{M}$. Como controle, hepatócitos foram tratados 
somente com o meio de cultura DMEM.

As células foram novamente incubadas a $37{ }^{\circ} \mathrm{C} / 5 \%$ de $\mathrm{CO}_{2}$ por 20 horas e o meio contendo as nanopartículas foi retirado e em seguida as culturas foram processadas de acordo com os protocolos específicos para os testes de redução do brometo de [(3-(4,5-dimetiltiazol2-il)-2,5-difeniltetrazólio] (MTT) e determinação do conteúdo de ácidos nucléicos (DNA), descritos a seguir. Estes ensaios foram realizados pelo menos duas vezes e em sextuplicata para cada concentração de nanopartículas. Hepatócitos do grupo controle tratados apenas com meio de cultura foram considerados como $100 \%$ viáveis. Os valores de $\mathrm{IC}_{50}$ foram obtidos por interpolação dos dados do gráfico de porcentagem de viabilidade celular versus as concentrações de nanopartículas.

a) Redução do MTT

O teste de redução do corante MTT foi realizado de acordo com o método de Denizot e Lang (1986). Após o tratamento o meio de cultura contendo as NP Ag em diferentes concentrações foi retirado e substituído por $100 \mu \mathrm{L}$ de meio DMEM contendo MTT (1 $\mathrm{mg} / \mathrm{mL}$ ) em cada cavidade. As placas foram incubadas por 4 horas a $37{ }^{\circ} \mathrm{C} / 5 \% \mathrm{CO}_{2} \mathrm{e}$ em seguida o sobrenadante foi removido e $100 \mu \mathrm{L}$ de etanol foram adicionados a cada cavidade para solubilizar o formazan produzido. As placas foram agitadas por 20 minutos e as absorbâncias das soluções foram determinadas em espectrofotômetro a $570 \mathrm{~nm}$.

b) Determinação do Conteúdo de Ácidos Nucléicos

O conteúdo de ácidos nucléicos foi estimado conforme procedimento descrito por Cingi et al. (1991). Após 20 horas de tratamento, o meio DMEM foi retirado e as células

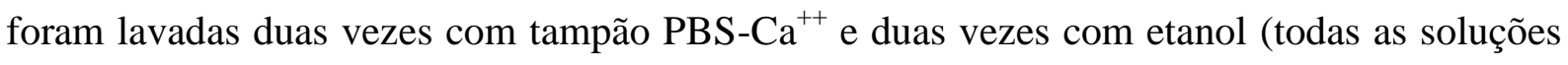
geladas). Após secagem a temperatura ambiente as células foram lisadas com $\mathrm{NaOH} 500 \mathrm{mM}$ $\left(100 \mu \mathrm{L} /\right.$ cavidade, 1 hora a $\left.37^{\circ} \mathrm{C}\right)$. As absorbâncias dos lisados foram determinadas a $260 \mathrm{~nm}$ para quantificação do conteúdo de ácidos nucleicos. 


\section{RESULTADOS E DISCUSSÃO}

\subsection{Síntese e Caracterização físico-química das NP Ag}

As quatorze linhagens de fungos codificadas como A-1-8, A-3BI-11, A-3BI-17, L-2-2, L-3BI-15, MGE-182, MGE-201, MGE-202, R-2BI-4, R-2BI-6, R-2BI-8, R-2BI-9, R-2BI-13 e R-3BI-10 foram cultivadas para a obtenção de filtrados fúngicos (FF) que foram empregados na avaliação da capacidade de conversão de prata. Dentre as 14 linhagens avaliadas, cinco foram mais efetivas na produção de NP Ag e as Figuras 1 e 2 mostram os espectros de absorbâncias $(250$ a $650 \mathrm{~nm}$ ) das NP obtidas a partir dessas cinco linhagens de fungos (L-2-2, R-2BI-4, MGE-201, MGE-202 e R-3BI-10) no tempo de 96 horas evidenciando a formação de uma banda de ressonância de Plasmon na região de 440 nm, característica da formação de NP Ag (DANIELS et al., 2005; PEREIRA, 2009).

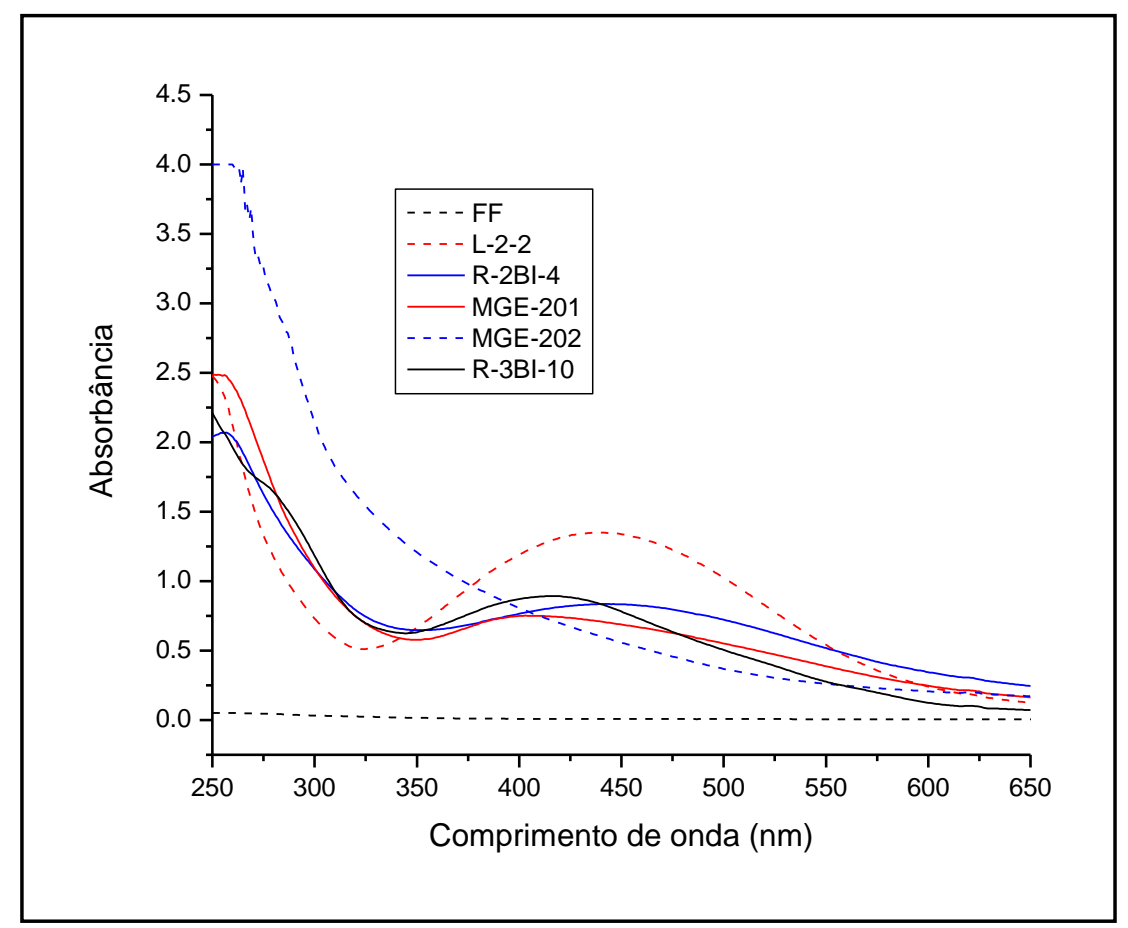

Figura 1. Perfil de absorbâncias de NP Ag obtidas a partir dos FF de L-2-2, R-2BI-4, MGE-201, MGE-202 e R-3BI-10 na região de 250 a 650 nm 96 horas após adição de nitrato de prata.

A mudança de cor dos FF após a adição de nitrato de prata foi observada. A Figura 3 mostra a mudança de cor do FF de MGE-201 tratado com nitrato de prata, de incolor para marrom-escuro, nas primeiras horas de reação, enquanto que outros FF não apresentaram esta alteração (dados não apresentados). Pode-se observar a presença de cor amarronzada 
resultante da redução de íons de $\mathrm{Ag}^{+}$para $\mathrm{Ag}^{0}$, confirmando a formação das $\mathrm{NP} \mathrm{Ag}$. Esta alteração de cor também ocorreu para os outros quatro FF (L-2-2, R-2BI-4, MGE-202 e R3BI-10).

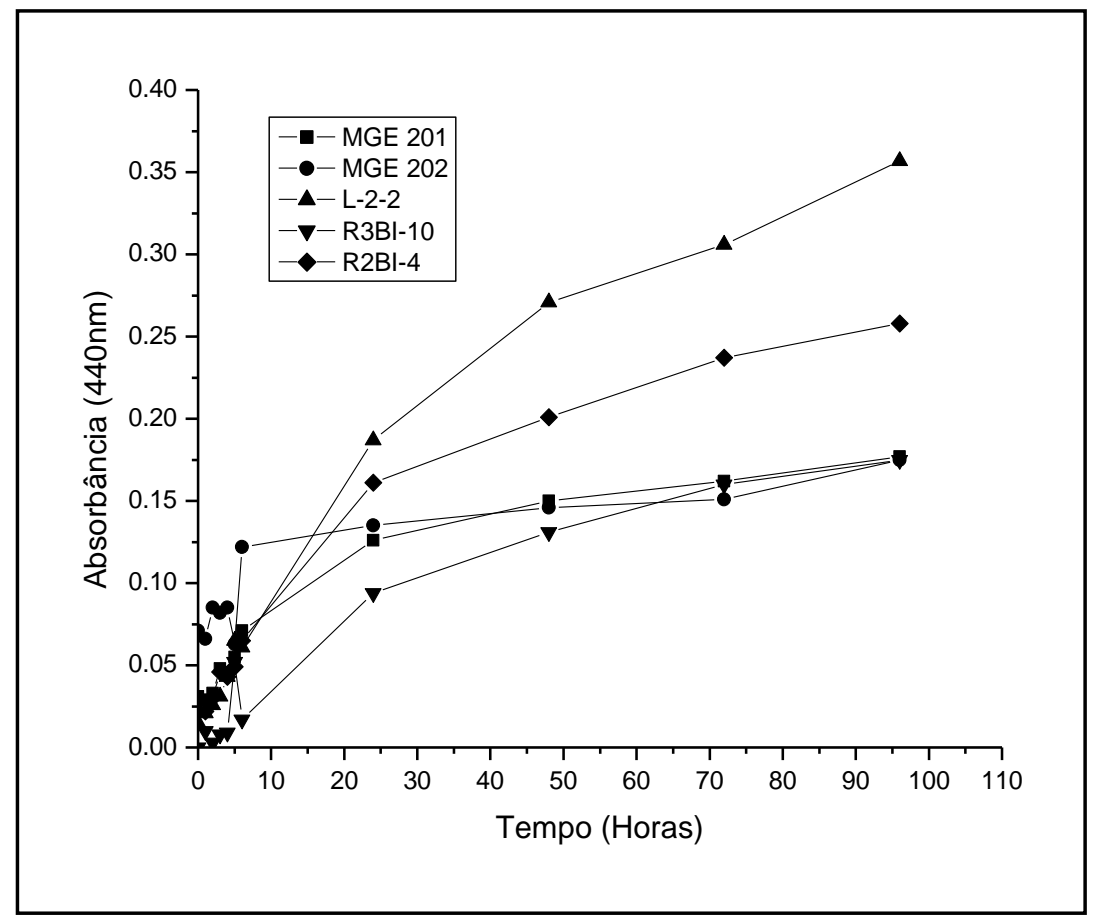

Figura 2 - Medidas de absorbâncias a $440 \mathrm{~nm}$ das dispersões de NP Ag obtidas a partir do FF utilizando os fungos MGE-201, L-2-2, R-2BI-4, MGE-202 e R-3BI10, no período de 0 a 96 horas.

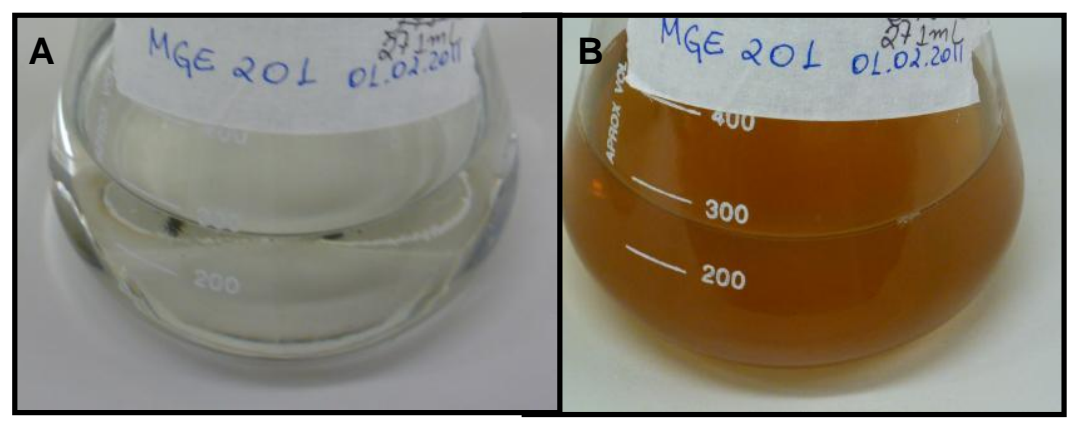

Figura 3 - (A) Filtrado fúngico obtido a partir da cultura do fungo MGE-201, e (B) dispersão de NP Ag obtidas a partir do FF de MGE-201. Observação da cor marrom 24 horas após a adição de nitrato de prata para concentração final de $1 \mathrm{mM}$.

O tamanho médio das NP, assim como o potencial zeta e a índice de polidispersão foram medidos por Espectroscopia de Correlação de Fótons e estão representados na Tabela 1. Considerando esses três parâmetros, as linhagens R-2BI-4, MGE-202, R-3BI-10, L-2-2 e 
MGE-201 apresentaram resultados satisfatórios na obtenção das NP Ag os quais as distinguiram em relação às demais linhagens.

O índice de polidispersão (IP) está relacionado com a uniformidade do tamanho das NP e quanto menor seu valor, maior a uniformidade do tamanho das partículas (com variação de 0 a 1). O potencial zeta (PZ) está relacionado com a carga na superfície das NP em relação ao meio líquido e, consequentemente, com a estabilidade das mesmas. Valores em módulo distantes de zero indicam maior força repulsiva entre as partículas, evitando formação de agregados e evidenciando uma dispersão mais estável. As linhagens R-2BI-6, A-1-8 e A-3BI11 apresentaram alto índice de polidispersão, e a linhagem R-2BI-6 apresentou tamanho médio de partícula chegando a quase um micrômetro. Com base nos dados apresentados na Tabela 2, e considerando os parâmetros acima descrito, cinco linhagens (R-2BI-4, MGE-202, R-3BI-10, L-2-2 e MGE-201) foram classificadas como mais efetivas na obtenção de NP. As linhagens L-2-2 e MGE-201 foram taxonomicamente identificadas e selecionadas para a continuidade do estudo.

Tabela 1 - Resultados das medidas de Índice de Polidispersão, Tamanho Médio, Potencial Zeta e Resposta do Programa para Tamanho Médio e Potencial Zeta de NP Ag obtidas a partir de 14 linhagens de fungos testadas.

\begin{tabular}{lccccc}
\hline Amostras & IP & TM $(\mathrm{nm})$ & PZ & RR-T & RP-PZ \\
\hline R-2BI-6 & 0,797 & 936,3 & $-36,2$ & BOM & BOM \\
R-2BI-4 & $\mathbf{0 , 1 8 1}$ & $\mathbf{2 7 6 , 8}$ & $\mathbf{- 1 , 5 9}$ & BOM & BOM \\
L-3BI-15 & 0,625 & 137,3 & $-28,2$ & RUIM & BOM \\
A-3BI-11 & 0,911 & 253,0 & $-3,95$ & BOM & BOM \\
MGE-202 & $\mathbf{0 , 2 2 5}$ & $\mathbf{1 6 5 , 8}$ & $\mathbf{9 , 9 2}$ & BOM & BOM \\
R-2BI-13 & 1 & 657,1 & 0,946 & RUIM & BOM \\
A-3BI-17 & 0,580 & 317,6 & $-15,9$ & RUIM & BOM \\
R3BI-10 & $\mathbf{0 , 2 7 5}$ & $\mathbf{2 4 3 , 2}$ & $\mathbf{- 2 1 , 4}$ & BOM & BOM \\
R-2BI-9 & 0,559 & 919,3 & $-22,6$ & RUIM & BOM \\
MGE-182 & 0,502 & 403,2 & 13,1 & RUIM & BOM \\
A-1-8 & 0,776 & 112,6 & $-15,9$ & RUIM & BOM \\
L-2-2 & $\mathbf{0 , 1 3 7}$ & $\mathbf{1 3 6 , 6}$ & $\mathbf{- 8 , 4 9}$ & BOM & BOM \\
R-2BI-8 & 0,507 & 184,4 & $-4,03$ & RUIM & BOM \\
MGE-201 & $\mathbf{0 , 3 3 7}$ & $\mathbf{3 1 3 , 1}$ & $\mathbf{7 , 7 9}$ & BOM & BOM \\
\hline
\end{tabular}


IP - Índice de Polidispersão; TM - Tamanho Médio; PZ - Potencial Zeta; RP-T - Resposta do Programa em relação ao Tamanho; RP-PZ - Resposta do Programa em relação ao Potencial Zeta

O estudo propunha inicialmente o emprego das duas linhagens de fungos mais efetivas para a síntese e caracterização físico-química das NP Ag. Assim, considerando a absorbância medida a $440 \mathrm{~nm}$ foi possível classificar as linhagens L-2-2 e R-2BI-4 como responsáveis por maior rendimento na síntese de NP. Entretanto, a linhagem MGE-201 apresentou valor de potencial zeta positivo, contrastando com os valores obtidos para as demais linhagens empregadas no estudo, que apresentaram valores de potencial zeta negativo e com dados da literatura. Esse dado é interessante porque as NP sintetizadas por este fungo poderiam ser usadas para outros fins, além do proposto nesse projeto, como em espalhamento Raman intensificado por superfície (SERS) (KANG et al., 2008).

Na literatura só há relatos de NP biogênicas com carga superficial negativa, como por exemplo, as partículas produzidas pelos fungos F. oxyporum e A.niger. Esta é a primeira vez, até o presente momento, da observação de NP Ag biogênicas com carga positiva. Considerando esta informação as NP Ag de L-2-2, MGE-201 e R-2BI-4 foram analisadas com relação ao tamanho e morfologia por MEV e os demais ensaios foram efetuados somente para NP Ag de L-2-2 e MGE-201.

Pela análise de MET as NP Ag obtidas a partir dos FF de L-2-2, R-2BI-4 e MGE-201 apresentaram tamanhos de 10-30 nm, conforme ilustrado na Figura 4. As NP provenientes do FF de L-2-2 são dispersas e uniformes quanto ao tamanho enquanto que as obtidas a partir de MGE-201 têm diferentes tamanhos e tendência a serem esféricas com formação de agregados. Já as NP obtidas a partir do FF de R-2BI-4 formaram agregados de forma pronunciada, resultado que corrobora com aquele verificado na medida de potencial zeta, próximo à zero, enquanto que as formas tendem a se manter esféricas.

Os valores de tamanho encontrados em análise por Microscopia Eletrônica de Transmissão (10-30 nm) (Figura 4) diferem daqueles encontrados por Espectroscopia de Correlação de Fótons (Tabela 2) porque estes últimos incluem também a camada da capa proteica que envolveria a NP, aumentando assim o seu tamanho médio aparente. Essa diferença provavelmente ocorre porque pela análise em PCS o diâmetro medido é o do raio hidrodinâmico, que leva em consideração a presença de proteínas ao redor das NP Ag. Estas proteínas formam uma camada altamente hidratada ao redor das partículas e consequentemente um raio hidrodinâmico maior é obtido. 
A análise por ESI mostrou a presença de $\mathrm{S}$ e $\mathrm{N}$ em torno da NP Ag obtida a partir do FF do fungo MGE-201, como mostrado na Figura 5 indicando que as partículas são estabilizadas por proteínas do fungo. O mesmo foi observado nas partículas obtidas a partir do FF do fungo L-2-2 (dados não apresentados). 


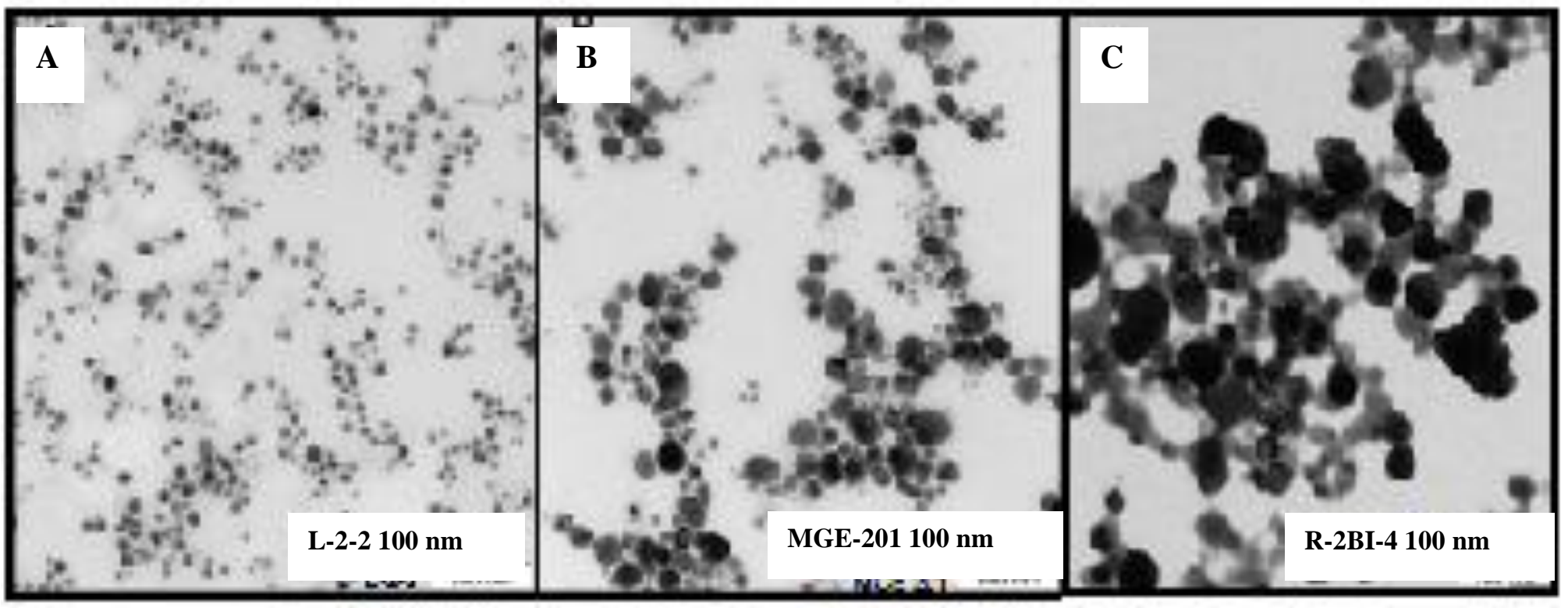

Figura 4 - Microscopia Eletrônica de Transmissão (MET) das dispersões de NP Ag obtidas a partir da cultura dos fungos (A) L-2-2 (B) MGE-201 e (C) R2BI-4. Ampliações de $100 \mathrm{~nm}$. 


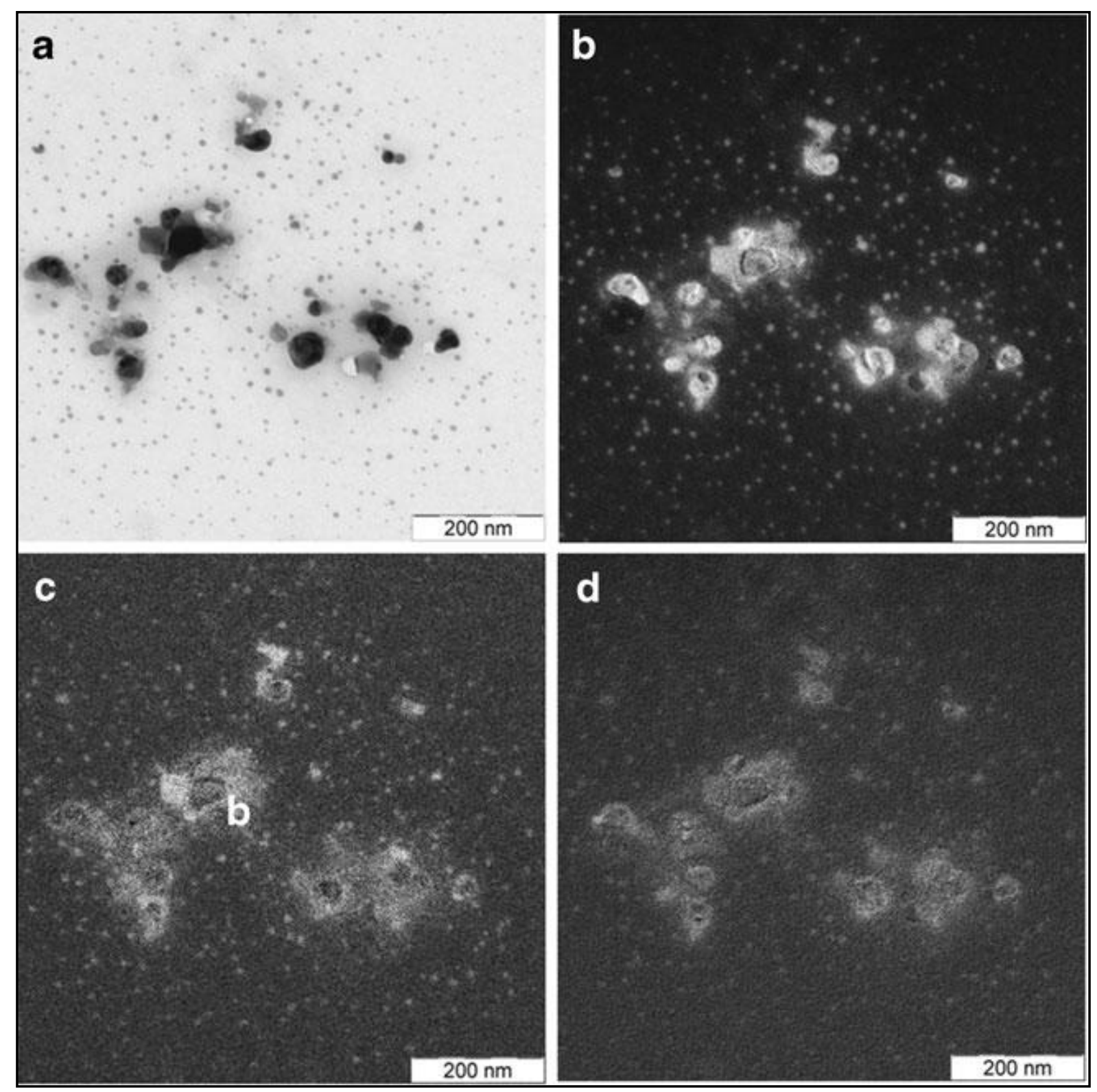

Figura 5 - Imagens dos elementos relevantes encontrados na amostra de MGE-201, usando elétrons monocromáticos correspondentes a enxofre L 2,3. Fenda seleção de energia fixada em $367 \pm 6 \mathrm{keV}$ para prata e $165 \pm 6 \mathrm{eV}$ para enxofre. A análise por ESI mostra a presença de: a) NP Ag, b), c) enxofre e d) nitrogênio.

\subsection{Identificação taxonômica dos isolados fúngicos}

Os fungos epifíticos L-2-2 e R-2BI-4 foram isolados a partir de folhas de L. racemosa e R. mangle, respectivamente. O fungo endófito codificado como MGE-201 foi isolado a partir de R. mangle de acordo com o método descrito por Araújo et al. (2001). 
Pela análise de identificação taxonômica a linhagem de fungo codificada como L-2-2 apresentou 99\% de similaridade de sequência com a espécie Bionectria ochroleuca.

A cepa MGE-201 apresentou $100 \%$ de similaridade de sequência com diferentes espécies do gênero Aspergillus. Para análise mais precisa, um sequenciamento genômico usando primer de beta-tubulina foi realizado e a sequência obtida apresentou $99 \%$ de similaridade com a espécie A. tubingensis (Tabela 1).

Tabela 2. Identificação molecular dos isolados de fungos codificados como L-2-2 e MGE- 201.

\begin{tabular}{llll}
\hline Cepas & $\begin{array}{l}\text { Query } \\
\text { coverage }\end{array}$ & $\begin{array}{l}\text { Max. } \\
\text { Identif. }\end{array}$ & Identificação \\
\hline L-2-2 (ITS) & $99 \%$ & $99 \%$ & Bionectria ochroleuca \\
MGE-201 (ITS) & $100 \%$ & $100 \%$ & Várias espécies de Aspergillus spp \\
MGE-201( $\beta$-tub) & $99 \%$ & $99 \%$ & Aspergillus tubingensis \\
\hline
\end{tabular}

Max. Identifi. - Máxima Identificação. ITS - sequenciamento com o uso de primer de $\beta$-tubulina.

Os fungos filamentosos usados neste trabalho, A. tubingensis e B. ochroleuca, fazem parte do grupo dos ascomicetos, que são fungos do filo Ascomycota (LIU et al., 1999.; TEPASKE et al., 1989a). Produzem esporos, e a maioria são patogênicos para plantas e são formados por hifas. Contém micélios septados, produzem esporos sexuados (conhecido como Teleomorfo ou Estado Perfeito) ou assexuados (Anamorfo ou Estado Imperfeito) (LESLIE; KLEIN, 1996). Os ascomicetos também participam da decomposição de moléculas orgânicas complexas, liberando componentes inorgânicos, que serão reutilizados por vegetais. (OSONO; FUKASAWA; TAKEDA, 2003).

O fungo Aspergillus tubingensis é um fungo endofítico cosmopolita, (LIU et al., 1999; TEPASKE et al., 1989a) tem sido estudado com relação à produção de metabólitos secundários, e como fonte de moléculas com atividade citotóxica contra linhagens de células cancerígenas (HUANG et al., 2011; ZHAN et al., 2007).

Bionectra ochroleuca é um fungo pode ser endófito e apresenta colônias geralmente esbranquiçadas, laranjadas ou salmão. Atualmente é considerado um micoparasita de um amplo espectro de espécies de fungos (GUU; JU; HSIEH, 2010; LI et al., 2002). 


\subsection{Análise das proteínas aderidas as nanopartículas por SDS-PAGE}

A análise das proteínas presentes no filtrado fúngico e na dispersão de NP Ag de L-2-2 por SDS-PAGE revelou a presença de três bandas com massas moleculares de 70, 100 e 174 $\mathrm{kDa}$ no FF de L-2-2 e quatro bandas com massas moleculares de 25, 30, 44 e $49 \mathrm{kDa}$ na dispersão de NP Ag (Figura 6). Para a linhagem MGE-201 foram encontradas quatro bandas com massas moleculares de 75, 122, 191 e 328 kDa tanto no FF como na suspensão de NP. Isso indica que as proteínas presentes no FF também estavam presentes durante a formação das NP.

As concentrações de proteína estão na mesma faixa, tanto nas NP Ag como no FF dos dois fungos. Para FF e NP Ag de MGE-201, a concentração foi de 0,89 mg/mL, e para L-2-2 0,76 e $0,74 \mathrm{mg} / \mathrm{mL}$ para NP Ag e FF, respectivamente.

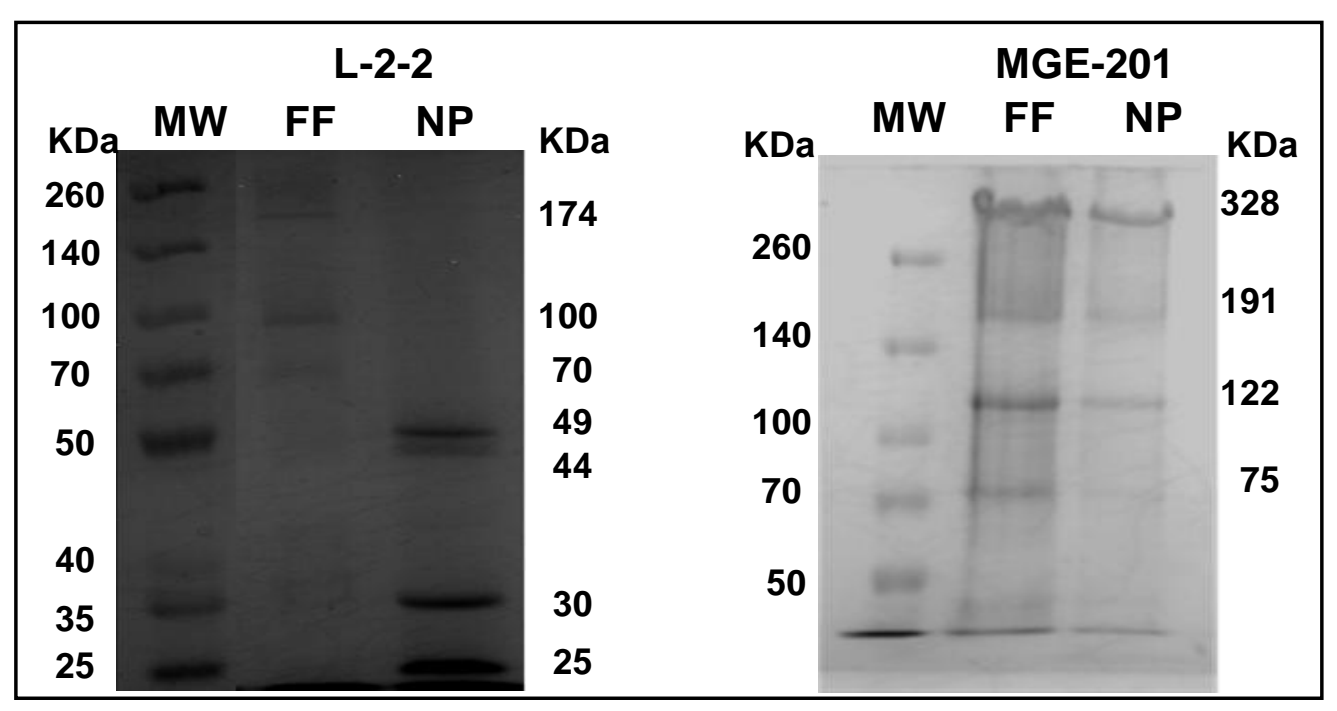

Figura 6 - SDS-PAGE 12\% e10\% para análise das proteínas presentes no FF e aderidas as NP obtidas a partir das linhagens L-2-2 e MGE-201, usando padrão de massa molecular com intervalo de 10 a $260 \mathrm{kDa}$. 


\subsection{Análise de proteínas por Cromatografia Líquida acoplada a Espectrometria de Massas (LC-MS)}

A Tabela 3 representa as proteínas identificadas no filtrado fúngico de MGE-201 (com score dentro da estatística confiável do Mascot) e as relaciona com os respectivos microrganismos.

Tabela 3 - Proteínas identificadas no filtrado fúngico de MGE-201 e respectivos microrganismos.

\begin{tabular}{lc}
\hline Proteínas identificadas & Microrganismo relacionado \\
\hline Proteína hipotética An01g11010 & Aspergillus niger \\
Preproglicoamilase G2 & Aspergillus niger \\
Proteína hipotética An04g08730 & Aspergillus niger \\
Fosfatase ácida & Aspergillus niger \\
Proteína hipotética An01g11010 & Aspergillus niger \\
Glicoamilase G1 & Aspergillus niger \\
Endoprotease Endo-Pro & Aspergillus niger \\
Proteína hipotética An03g05200 & Aspergillus niger \\
Proteína hipotética An09g00670 & Aspergillus niger \\
\hline
\end{tabular}

\subsection{Análise de Proteínas por Emissão de Fluorescência}

A espectroscopia de emissão de fluorescência foi utilizada para a análise de proteínas, presentes nos FF e na dispersão de NP Ag de MGE-201 e L-2-2, contendo resíduos de aminoácidos aromáticos característicos, como a tirosina, a fenilalanina e o triptofano, em que este último (Trp, W) é considerado o mais importante. Como não é um resíduo muito abundante, quando está presente, a interpretação do espectro se torna mais fácil (LAKOWICZ, 1983). O W é altamente sensível ao ambiente local, apresentando diferentes características de emissão de fluorescência dependendo do grau de exposição ao meio hidrofílico ou hidrofóbico (ANO BOM, 2010).

A Figura 7 mostra que as NP Ag de L-2-2 e de MGE-201 apresentaram sinais de fluorescência característicos de proteínas, sendo: $\lambda_{1 \max } \sim 350 \mathrm{~nm}$ - resíduos de aminoácidos aromáticos (triptofano, tirosina e cisteína); $\lambda_{2 \max } \sim 425 \mathrm{~nm}-\mathrm{NP}$ Ag e $\lambda_{3 \max } \sim 488 \mathrm{~nm}-\mathrm{NP}$ Ag (NP Ag produzidas por fungo L-2-2). 
Com comprimento de onda de excitação igual a $280 \mathrm{~nm}$, a suspensão das NP Ag apresentou um máximo de emissão em $350 \mathrm{~nm}$ e dois outros picos em 425 e em $488 \mathrm{~nm}$. Esta emissão de fluorescência das NP Ag está relacionada com a presença de pequenos clusters envolvendo alguns átomos de prata que se adsorvem na superfície das NP (MAALI et al., 2003). Além disso, a formação de óxido de prata também induz a emissão de fluorescência (ANGELESCU; MAGNO; STUBENRAUCH, 2010), a qual não é observada para sistemas livres de oxigênio. Sendo assim, como as NP foram preparadas ao ar livre (e não sob atmosfera inerte), pode ter ocorrido oxidação parcial da prata metálica para íons prata, formando estas espécies carregadas na superfície, dando origem a emissão em $\sim 425$ e $~ 490$ nm. Nos FF de MGE-201 e L-2-2 observou-se a banda de emissão máxima em 350 nm. Esta banda, tanto no espectro do FF quanto no espectro das NP, aparece como resultado da emissão dos resíduos de aminoácidos aromáticos das proteínas (triptofano, tirosina e fenilalanina), que, neste caso, estão expostos ao solvente. A natureza destas bandas indica a presença de proteínas tanto no FF como nas dispersões de NP (AHMAD et al., 2003; MACDONALD; SMITH, 1996).

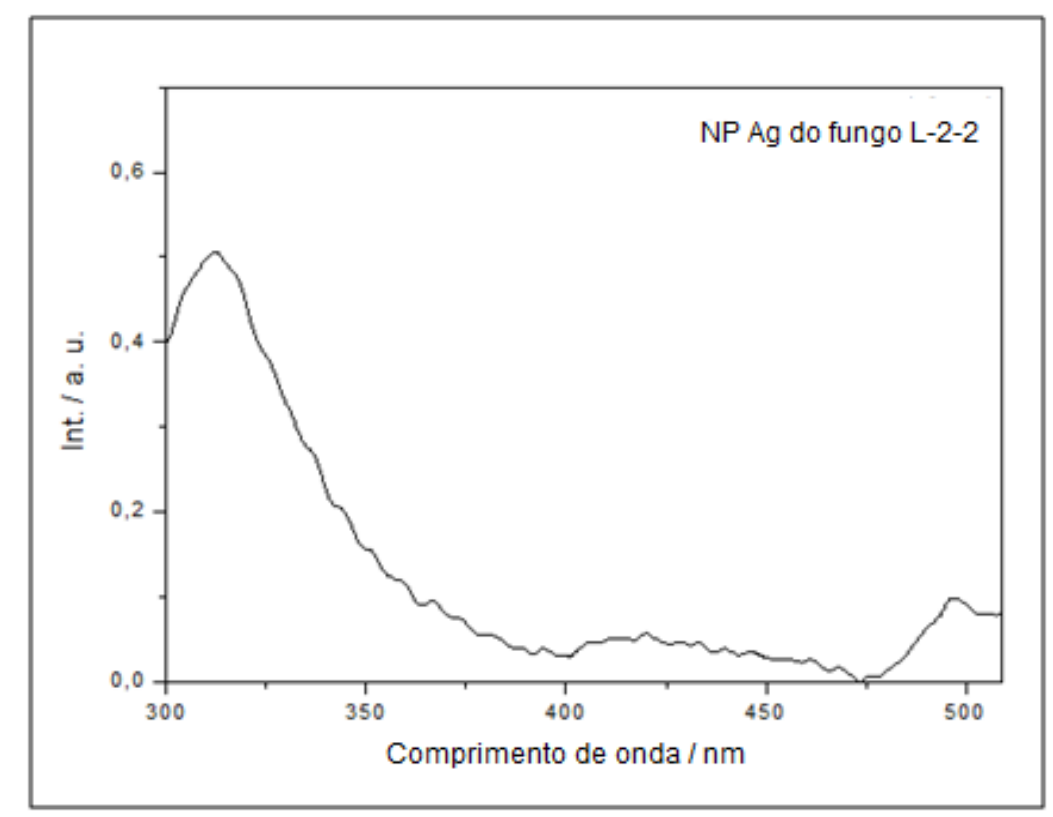

Figura 7 - Espectros de emissão de fluorescência para NP Ag de L-2-2 $\left(\lambda_{\text {exc }}=280 \mathrm{~nm}\right)$. 


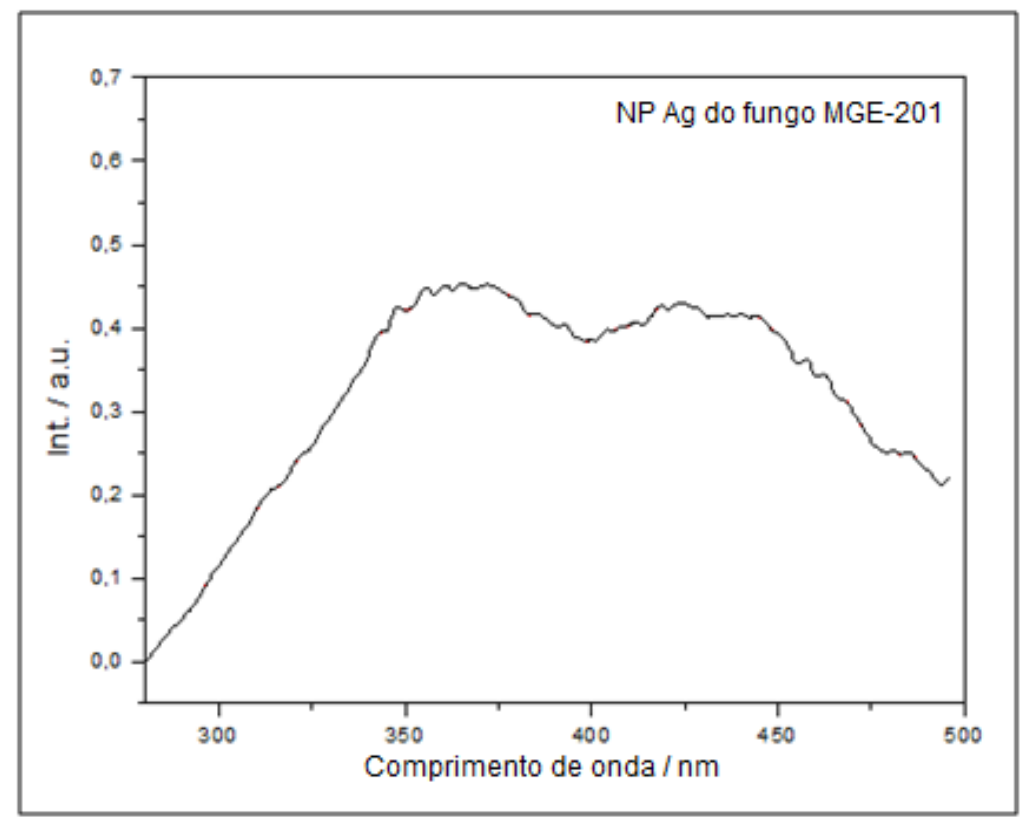

Figura 8 - Espectros de emissão de fluorescência para NP Ag de MGE-201 $\left(\lambda_{\text {exc }}=280 \mathrm{~nm}\right)$.

\subsection{Análise de Proteínas por Espectroscopia de Infravermelho Próximo (FTIR)}

A espectroscopia no infravermelho se baseia no fato de que as ligações químicas das substâncias possuem frequências de vibrações específicas às quais correspondem à níveis de energia da molécula (chamados nesse caso de níveis vibracionais). Estas frequências dependem da forma da superfície de energia potencial da molécula, da geometria molecular, das massas dos átomos e eventualmente do acoplamento vibrônico. Os espetros de IR adquiridos para NP Ag de L-2-2 e MGE-201 apresentaram os mesmos sinais referentes a bandas características de proteínas (Figura 8) (SILVERSTEIN et al., 2005).

Nas figuras 9 e 10 observam-se picos de absorção característicos localizados na região de $3400-3500 \mathrm{~cm}^{-1}$, referentes às vibrações N-H das ligações peptídicas das proteínas. As bandas 2920-2950 $\mathrm{cm}^{-1}$ são atribuídas às vibrações simétricas e assimétricas dos grupos C-H, bandas de 1620 a $1650 \mathrm{~cm}^{-1}$ são atribuídas aos anéis aromáticos e de 1380 e $1030 \mathrm{~cm}^{-1}$ são associadas às vibrações $\mathrm{C}-\mathrm{N}$. A posição das bandas está próxima àquelas descritas para proteínas em suas formas nativas (EFTINK; GHIRON, 1981; GOLE et al., 2001; RANI; RAJASEKHARREDY, 2011), de acordo com as análises por fluorescência de emissão. Os resultados de FTIR também indicam que a estrutura secundária das proteínas não foi afetada como consequência da reação dos íons prata ou da ligação com as NP Ag. Os resultados de FTIR corroboram com os obtidos por outros grupos de pesquisa (GOLE et al., 2001; MANDAL et al., 2005) que descreveram a possibilidade da ligação das proteínas às NP tanto 
pelos grupos amino livres, quanto pelos resíduos de cisteína das proteínas ou ainda pela interação eletrostática de grupos carboxilados carregados negativamente (INGLE et al., 2009).

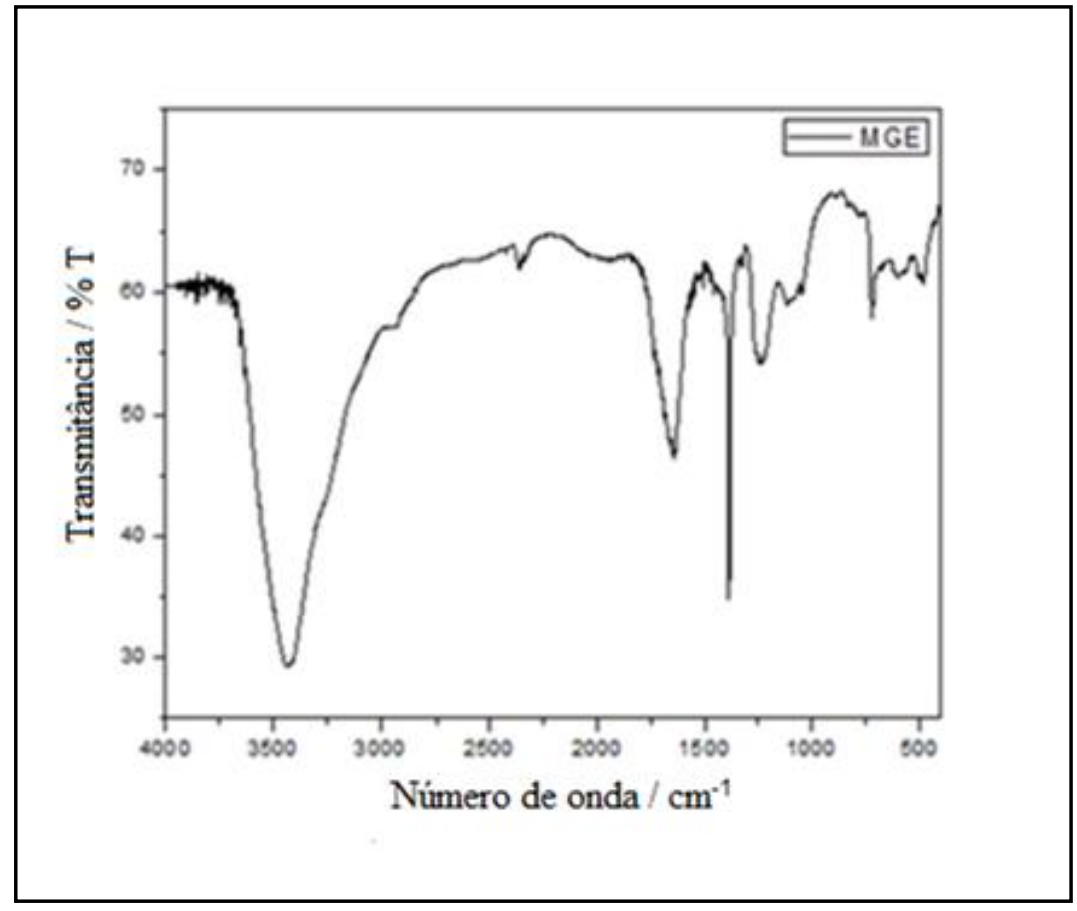

Figura 9 - Espectros de Infra-vermelho (FTIR) para NP Ag de MGE-201.

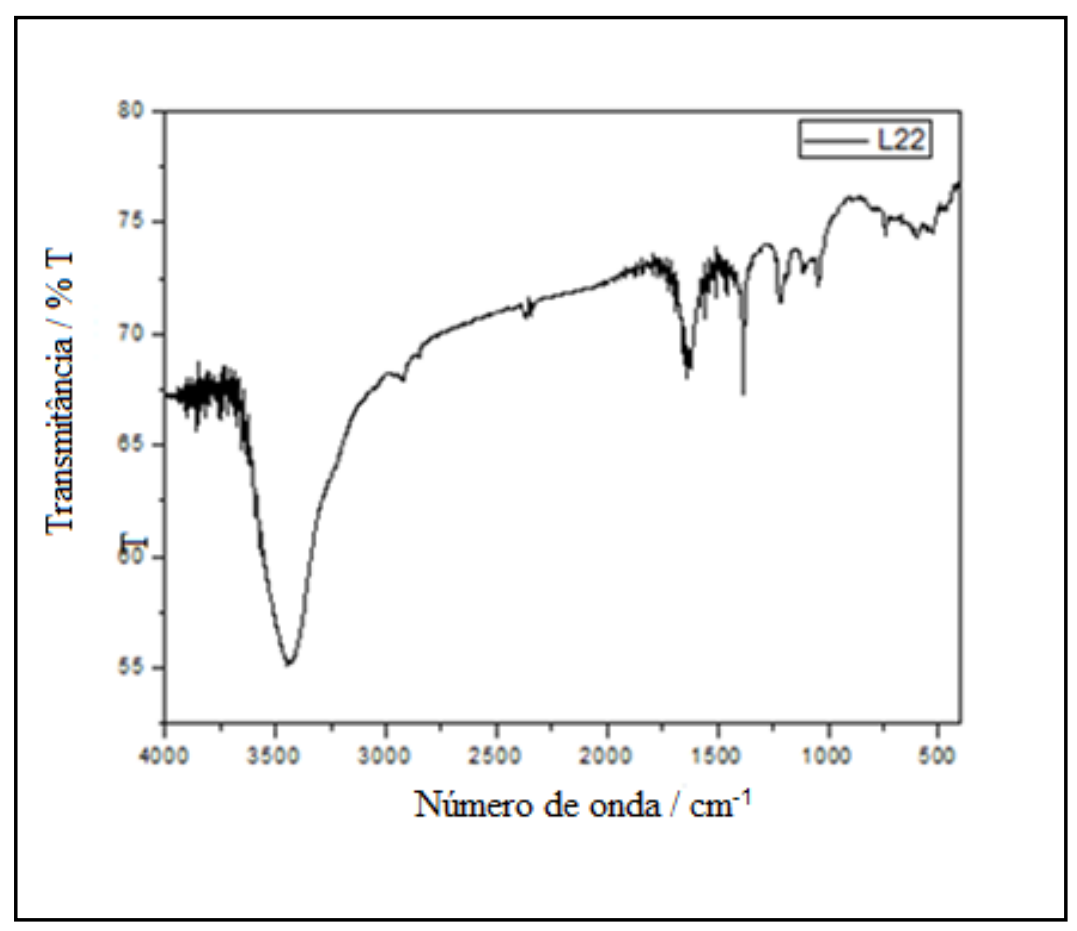

Figura 10 - Espectros de Infra-vermelho (FTIR) para NP Ag de L-2-2. 


\subsection{Avaliação da porcentagem de incorporação das NP Ag nos tecidos de algodão e poliéster}

A Tabela 4 mostra a porcentagem de impregnação das NP Ag produzidas pelos fungos MGE-201 e L-2-2 nos tecidos de algodão e poliéster em função do número de impregnações. Nesta tabela pode-se observar que para os tecidos de algodão quanto maior foi o número de impregnações maior foi à porcentagem de NP Ag incorporada, sendo que, com 4 vezes de impregnação obteve-se maiores porcentagens de NP Ag aderidas às fibras para nanopartículas obtidas de ambos os fungos. Entretanto, no caso dos tecidos de poliéster, o comportamento foi oposto, sendo obtido maiores porcentagens de NP Ag nos tecidos impregnados por somente 1 vez. Esta tendência foi mais evidente no caso das NP Ag obtidas a partir do fungo L-2-2. Este resultado indica que para os tecidos de poliéster um ciclo de impregnação é adequado para maior aderência das partículas enquanto que para as fibras de algodão o aumento da quantidade de nanopartículas impregnadas foi diretamente proporcional com o aumento do número de impregnações. Outro ponto relevante foi a maior adesão das NP Ag produzidas pelo fungo MGE-201 nas fibras comparadas com as NP Ag produzidas pelo fungo L-2-2. Esta diferença pode estar relacionada com a carga superficial das nanopartículas sendo que as partículas produzidas pelo fungo MGE-201 apresentaram carga positiva enquanto que as preparadas com o fungo L-2-2 apresentaram carga superficial negativa.

Tabela 4 - Porcentagem de incorporação das NP Ag preparadas a partir dos fungos MGE-201 e L-2-2 nos tecidos de algodão e poliéster.

\begin{tabular}{ccccc}
\hline & \multicolumn{2}{c}{ NP Ag MGE-201 (\%) } & \multicolumn{2}{c}{ NP Ag L-2-2 (\%) } \\
\hline $\mathbf{N}^{\mathbf{0}}$. impregnações & Algodão & Poliéster & Algodão & Poliéster \\
\hline 1 & 2,7 & 9,9 & 0,1 & 6,0 \\
2 & 2,7 & 9,3 & 3,0 & 4,4 \\
4 & 12,5 & 8,4 & 9,9 & 1,6 \\
\hline
\end{tabular}

A concentração de prata nas dispersões de NP Ag antes dos processos de impregnação, medida por ICP, foi de 19,3 $\mu \mathrm{g} / \mathrm{mL}$ e 15,75 $\mu \mathrm{g} / \mathrm{mL}$ para MGE-201 e L-2-2, respectivamente. Esse resultado demonstra um rendimento de 11,35\% para L-2-2 e 9,26\% para MGE-201 na conversão de $\mathrm{Ag}^{+} \mathrm{a} \mathrm{Ag}^{0}$. 


\subsection{Atividade Antimicrobiana}

As NP Ag obtidas a partir das cinco linhagens de fungos mais efetivas foram avaliadas quanto à ação antibacteriana e antifúngica e os dados estão sendo apresentados somente para as duas linhagens selecionadas para o estudo. Tecidos impregnados com as NP Ag foram avaliados em espécies de Candida albicans, C. tropicalis e C. glabrata.

\subsubsection{Ação antifúngica das NP Ag}

As NP Ag obtidas a partir desses dois fungos apresentaram atividade antifúngica contra oito espécies de Candida sp comuns em infecções hospitalares, com MIC no intervalo de 0,22-1,75 mg/mL (2-16 $\mu \mathrm{M}$ ) (Tabela 5). As espécies de C. albicans (IOC 4525) e C. krusei (IOC 4559) foram os mais sensíveis à ação das NP Ag, com o crescimento inibido a partir de 0,22 ng/ml de NP Ag (2 $\mu \mathrm{M})$. As espécies C. albicans (IOC 4558), C. krusei (IOC 4559), C. glabrata, C. guillermondi (IOC 4557) e C. parapsilosis (IOC 4564), foram inibidas numa CIM próxima a do antifúngico Anfotericina $\mathrm{B}$, mostrando uma elevada atividade antifúngica das NP Ag contra os patógenos testados.

Tabela 5 - Concentrações Inibitórias Mínimas (CIMs), em $\mu \mathrm{g} / \mathrm{mL}$ e $\mu \mathrm{M}$, de NP Ag preparadas a partir dos FF de MGE-201e L-2-2 contra espécies Candida sp.

\begin{tabular}{|c|c|c|c|c|c|c|}
\hline \multirow[b]{3}{*}{ C. albicans ATCC 36802} & \multicolumn{6}{|c|}{$\mathrm{MIC} \mu \mathrm{g} / \mathrm{mL}$ e $\mu \mathrm{M}^{*}$} \\
\hline & \multicolumn{2}{|c|}{ L-22 } & \multicolumn{2}{|c|}{ MGE201 } & \multicolumn{2}{|c|}{ AMB } \\
\hline & 0,033 & $3 *$ & 0,033 & $3 *$ & $\leq 0,005$ & $\leq 0,5^{*}$ \\
\hline C. albicans IOC 4525 & 0,035 & $3,16^{*}$ & 0,040 & $3,66^{*}$ & $\leq 0,005$ & $\leq 0,5^{*}$ \\
\hline C. albicans IOC 4558 & 0,124 & $11,3 *$ & 0,066 & $6^{*}$ & 0,011 & $1 *$ \\
\hline C. krusei IOC 4559 & 0,029 & $2,6^{*}$ & 0,025 & $2,3 *$ & $\leq 0,005$ & $\leq 0,5^{*}$ \\
\hline C. glabrata IOC 4565 & 0,033 & $3 *$ & 0,075 & $6,8 *$ & $\leq 0,005$ & $\leq 0,5^{*}$ \\
\hline C. guillermondi IOC 4557 & 0,015 & $1,3 *$ & 0,024 & $2,2 *$ & $\leq 0,005$ & $\leq 0,5^{*}$ \\
\hline C.parapsilosis IOC 4564 & 0,022 & $2 *$ & 0,033 & $3 *$ & $\leq 0,005$ & $\leq 0,5^{*}$ \\
\hline C. tropicalis IOC 4560 & 0,132 & $12 *$ & 0,058 & $5,3 *$ & $\leq 0,005$ & $\leq 0,5^{*}$ \\
\hline
\end{tabular}

*Concentrações em $\mu \mathrm{M}$. AMB na concentração de $64 \mu \mathrm{g} / \mathrm{mL}$ 
Apesar do potencial zeta positivo, as NP Ag obtidas a partir do FF de MGE-201 demonstraram atividade antifúngica semelhante à das NP de L-2-2 com potencial zeta negativo. Sendo que, as NP sintetizadas a partir do FF de MGE-201 foram as que melhor inibiram o crescimento dos patógenos na concentração de 2,2 a $6,8 \mu \mathrm{M}$. As NP preparadas usando o fungo L-2-2 foram as que apresentaram a segunda e terceira melhor faixa de inibição (1,3 a 44,6 $\mu \mathrm{mol} / \mathrm{mL})$ (Tabela 5).

\subsubsection{Ação Antibacteriana das NP Ag}

Ambos os patógenos E. coli e M. luteus foram os mais resistentes e praticamente insensíveis às NP Ag de L-2-2 e MGE-201 na concentração de 0,14 $\mu \mathrm{g} / \mathrm{mL}$ (Tabela 6).NP Ag

Na concentração de $1,1 \mu \mathrm{g} / \mathrm{mL}$ as NP de L-2-2 inibiram o crescimento de $M$. luteus e E. coli em 65,6 e 67\%, respectivamente, enquanto que $S$. aureus e P. aeruginosa foram inibidos em 98 e 100,0\%, respectivamente. Na concentração de $2,2 \mu \mathrm{g} / \mathrm{mL}$ essas NP inibiram completamente o crescimento de P. aeruginosa, S. aureus e E. coli e inibiram $84,3 \%$ do crescimento de M. luteus.

As nanopartículas de MGE-201 foram bastante efetivas sobre todos os patógenos e na concentração de $0,28 \mu \mathrm{g} / \mathrm{mL}$ a inibição dos crescimentos de $P$. aeruginosa e de $S$. aureus foi de $98 \%$ e $58 \%$, respectivamente. Nas concentrações de 1,1 e $2,2 \mu \mathrm{g} / \mathrm{mL}$ a inibição foi de $100 \%$ para E. coli, S. aureus e P. aeruginosa e de 87,5 para M. luteus.. 
Tabela 6 - Concentrações Inibitórias Mínimas (CIMs) em $\mu \mathrm{M}$ de nanopartículas de prata sintetizadas a partir dos filtrados fúngicos de MGE-201 e L-2-2 contra E. coli, S.aureus, P. aeruginosa eM. luteus.

\begin{tabular}{cccccc}
\hline \multicolumn{2}{c}{$\begin{array}{c}\text { Concentrações } \\
(\boldsymbol{\mu g} / \mathbf{m L})\end{array}$} & $\boldsymbol{E}$. coli & S. aureus & P. aeruginosa & M. luteus \\
\hline NP Ag L-2-2 & 0,14 & 0 & 0 & 0 & 0 \\
& 0,28 & 18,8 & 8,5 & 19,7 & 0 \\
& 0,54 & 27,1 & 69,9 & 81,0 & 0 \\
& 0,71 & 38,3 & 75,5 & 78,0 & 20,0 \\
& 1,10 & 65,6 & 98,0 & 100,0 & 67,0 \\
& 2,20 & 99,8 & 100,0 & 100,0 & 84,3 \\
\hline NP Ag MGE- & 0,14 & 0 & 0 & 3,0 & 0 \\
201 & 0,28 & 27,6 & 58,0 & 98,0 & 0 \\
& 0,54 & 49,8 & 80,2 & 100,0 & 0 \\
& 0,71 & 63,4 & 98,9 & 97,9 & 80,0 \\
& 1,10 & 100,0 & 100,0 & 100,0 & 87,5 \\
& 2,20 & 100,0 & 100,0 & 100,0 & 96,8 \\
\hline Gentamicina & 8,0 & 87,1 & 98,2 & 92,7 & 82,0 \\
& 16,0 & 88,9 & 99,5 & 95,5 & 88,0 \\
\hline
\end{tabular}

Em geral a inibição dos patógenos foi mais alta quando nanopartículas obtidas pelo fungo MGE-201 foram usadas, com destaque para maior inibição de $P$. aeruginosa e $S$. aureus nos dois casos e uma inibição acima de $65 \%$ contra todos os patógenos tanto para as NP Ag de L-2-2 quanto de MGE-201, como é possível observar nas figuras 11 e 12. Ambas As NP Ag foram mais eficazes do que a gentamicina, considerando que o fármaco inibiu apresentou inibição mínima de $82 \%$ do crescimento bacteriano na concentração de $8 \mu \mathrm{g} / \mathrm{mL}$.

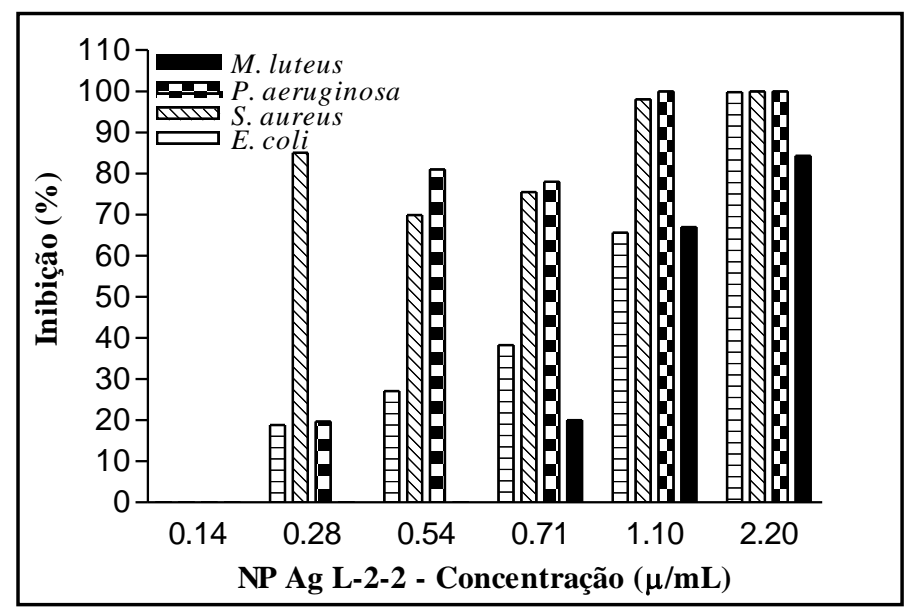

Figura 11 - Atividade antibacteriana de NP Ag de L2-2 em diferentes concentrações contra M. luteus, $P$. aeruginosa, S. aureus e E. coli. 


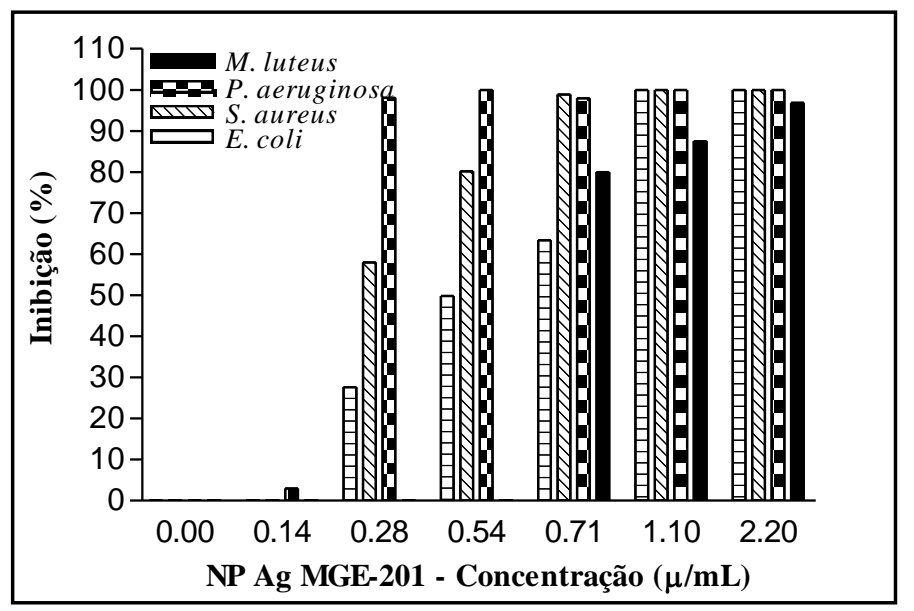

Figura 12 - Atividade antibacteriana de NP Ag de MGE-201 em diferentes concentrações contra $M$. luteus, $P$. aeruginosa, $S$. aureus e E. coli.

\subsection{Microscopia Eletrônica de Varredura dos tecidos de algodão e poliéster impregnados com NP Ag}

O ensaio com microscopia eletrônica de varredura dos tecidos de algodão e poliéster não revelaram grandes diferentes de impregnação entre os tecidos empregados no estudo. Como pode sere observado na figura 13, o tecido de algodão sem nanoparículas de prata manteve sua textura e não apresenta a presença do metal. Por outo lado os tecidos impregnados com NP Ag obtidas a partir do fungo MGE-201 teve sua superfície alterada, resultando em uma textura mais rugosa, além de apresentar a presença da prata em alguns pontos, mais evidente quando o tecido foi impregnado por 4 vezes do que um vez. Um comportamento similar pode ser observado nas figura 14, que mostra microscopias de tecido de algodão impregnado com água como controle e dispersão de nanopartículas obtidas a partir do fungo L-2-2. Em relação ao tecido de poliéster impregnado com NP Ag, é possível observar a presença de prata no tecido impregnado uma vez. No entanto, a presença do metal não é tão evidente no tecido impregnado quatro vezes (figura 15). A textura, nesse caso, apresentou menor alteração, quando comparado ao tecido de algodão. A figura 16 mostra o tecido de poliéster impregnado com água e dispersão de nanopartículas obtidas a partir do fungo L-2-2. A presença de prata é menos evidente do que no caso anterior, quase não demonstrando haver presença do metal nessa parte do tecido em nenhuma das amostras analisadas. 

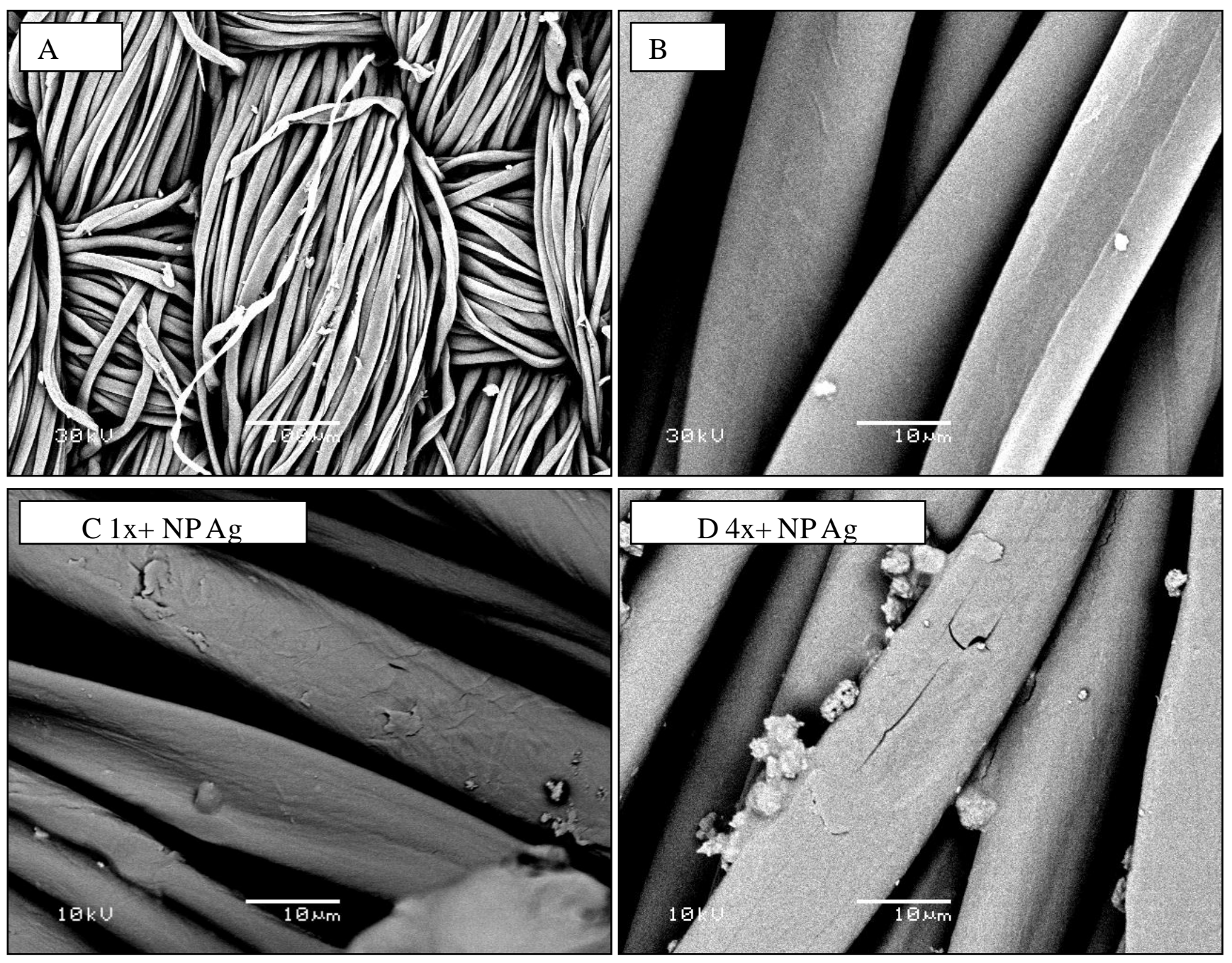

Figura 13 - Microscopia Eletrônica de Varredura de tecido de algodão. Controle não impregnado com nanopartículas (A) e (B) e tecido de algodão impregnado com NP Ag de MGE-201 por 1X (C) e 4x (D). 


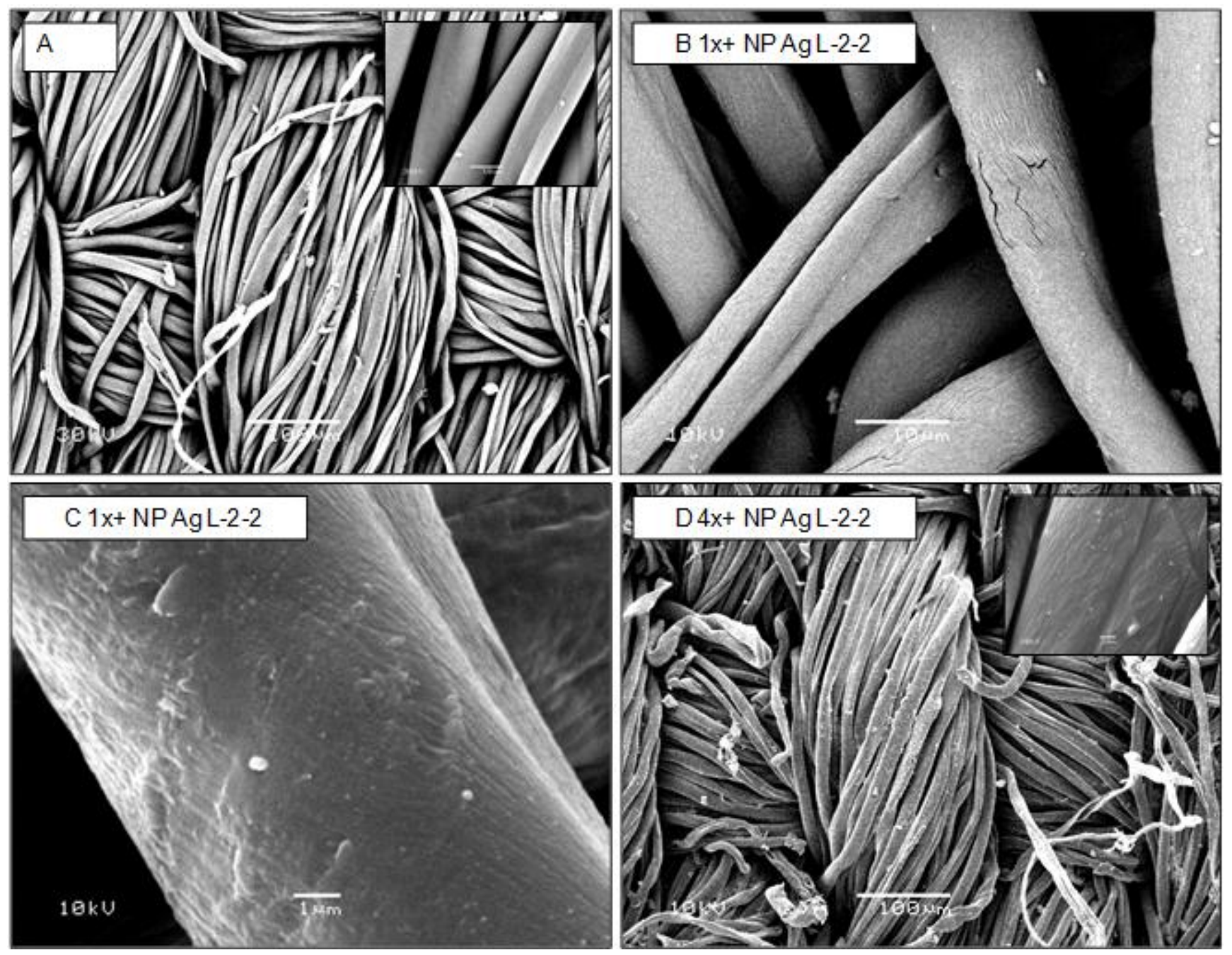

Figura 14 - Microscopia Eletrônica de Varredura de tecido de algodão controle não impregnada com nanopartículas (A) e de tecido de algodão impregnado com NP Ag de L-2-2 por 1X (B) e (C) e 4x (D). 

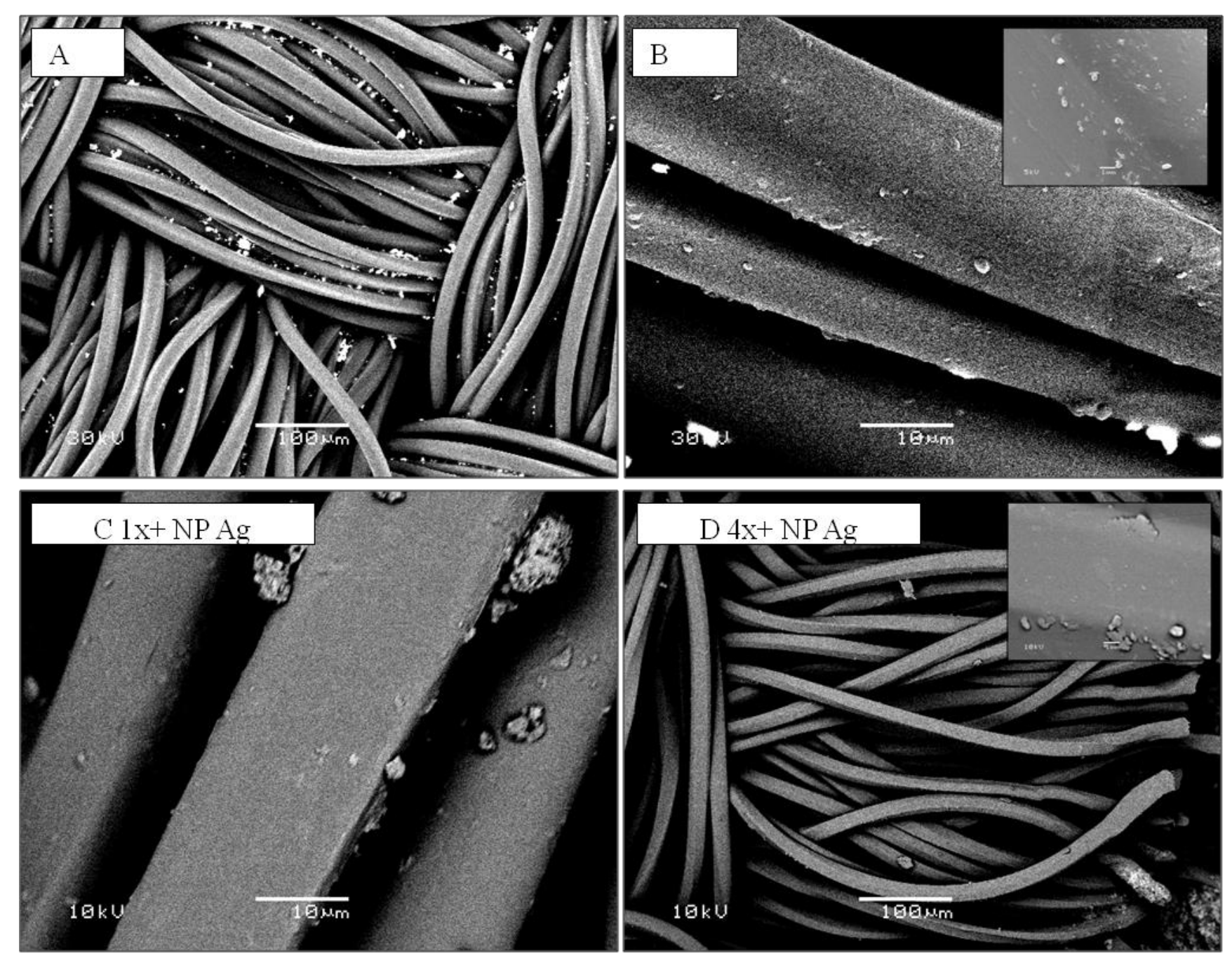

Figura 15 - Microscopia Eletrônica de Varredura de tecido de poliéster controle não impregnado (A) e (B), e de tecido de poliéster impregnado com NP Ag de MGE-201 por 1X (C) e 4X (D) e 4x (D). 

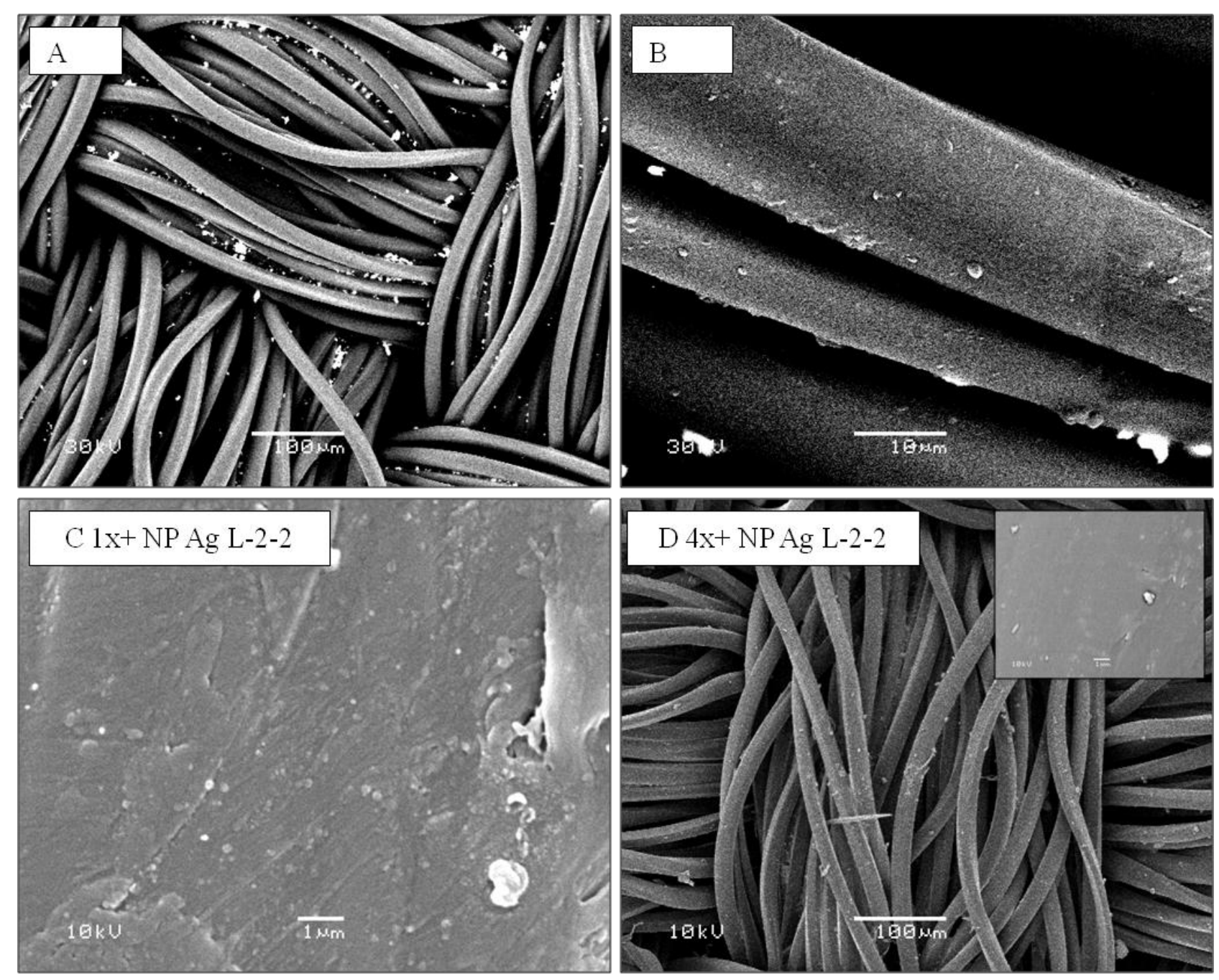

Figura 16 - Microscopia Eletrônica de Varredura de tecido de poliéster. Controle não impregnado com nanopartículas (A) e (B), e de tecido de poliéster impregnado com NP Ag de L-2-2 por 1X (C) e 4X (D). 


\subsection{Ação antifúngica de tecidos impregnados com NP Ag}

A ação antifúngica do tecido de algodão impregnado com NP Ag de MGE-201 ou L2-2 não foi proporcional ao aumento da porcentagem de incorporação de nanopartículas nos tecidos testados sobre a espécie de C. albicans IOC 3704/ATCC 36802 (Tabela 7). No caso do tecido de poliéster o aumento do número de impregnações resultou em menor porcentagem de incorporação das NP Ag e não ocorreram grandes variações na porcentagem de inibição do patógeno. Quando carreadas em tecidos, no geral, as NP Ag de MGE-201 apresentaram certa vantagem em relação à inibição, enquanto que aquelas de L-2-2, apesar de demonstrarem alguma eficácia, não foram capazes de diminuir a população de patógenos, quando comparado ao controle.

Tabela 7 - Ação antifúngica de tecidos de algodão e poliéster impregnados com NP Ag de L-2-2 e MGE-201 por 1x, 2x e 4x sobre C. albicans IOC 3704/ATCC 36802.

\begin{tabular}{ccc}
\hline $\begin{array}{c}\text { Amostras } \\
\text { NP Ag MGE-201* }\end{array}$ & UFC/mL & \% Inibição \\
\hline Controle & $4,49 \times 10^{6}$ & 0 \\
Algodão 1x & $8,95 \times 10^{5}$ & 80,07 \\
Algodão 2x & $8,73 \times 10^{5}$ & 80,56 \\
Algodão 4x & $7,39 \times 10^{5}$ & 83,54 \\
Poliéster 1x & $6,16 \times 10^{5}$ & 86,28 \\
Poliéster 2x & $6,7 \times 10^{5}$ & 85,08 \\
Poliéster 4x & $1,07 \times 10^{6}$ & 76,17 \\
\hline NP Ag L-2-2*** & & \\
\hline Controle & $8,8 \times 10^{6}$ & 0 \\
Algodão 1x & $2,78 \times 10^{6}$ & 68,41 \\
Algodão 2x & $2,2 \times 10^{6}$ & 75 \\
Algodão 4x & $3,35 \times 10^{6}$ & 67,93 \\
Poliéster 1x & $1,58 \times 10^{6}$ & 82,05 \\
Poliéster 2x & $2,86 \times 10^{6}$ & 67,50 \\
Poliéster 4x & $2,54 \times 10^{6}$ & 71,14 \\
\hline
\end{tabular}

*Média de dois ensaios independentes em duplicata e ** média de um ensaio em duplicata. UFC $/ \mathrm{mL}=$ unidades formadoras de colônias/mL na suspensão de $C$. albicans IOC 3704/ATCC 36802. \% NP Ag $=\%$ NP Ag impregnadas

De modo similar aos dados anteriores, à atividade dos tecidos de algodão e poliéster impregnados com nanopartículas de L-2-2 e MGE-201 por uma vez contra outras espécies de Candida apresentou razoável atividade antifúngica, sendo que para $C$. parapsilosis e $C$. glabrata houve redução de $10 \%$ da população de patógeno, e C. glabrata sendo o mais resistentes dos patógenos testados (Tabela 8). 
Tabela 8 - Ação antifúngica contra $C$. albicans de tecidos de algodão e poliéster impregnados 1x com NP Ag obtidas a partir da cultura dos fungos MGE-201 e L-2-2.

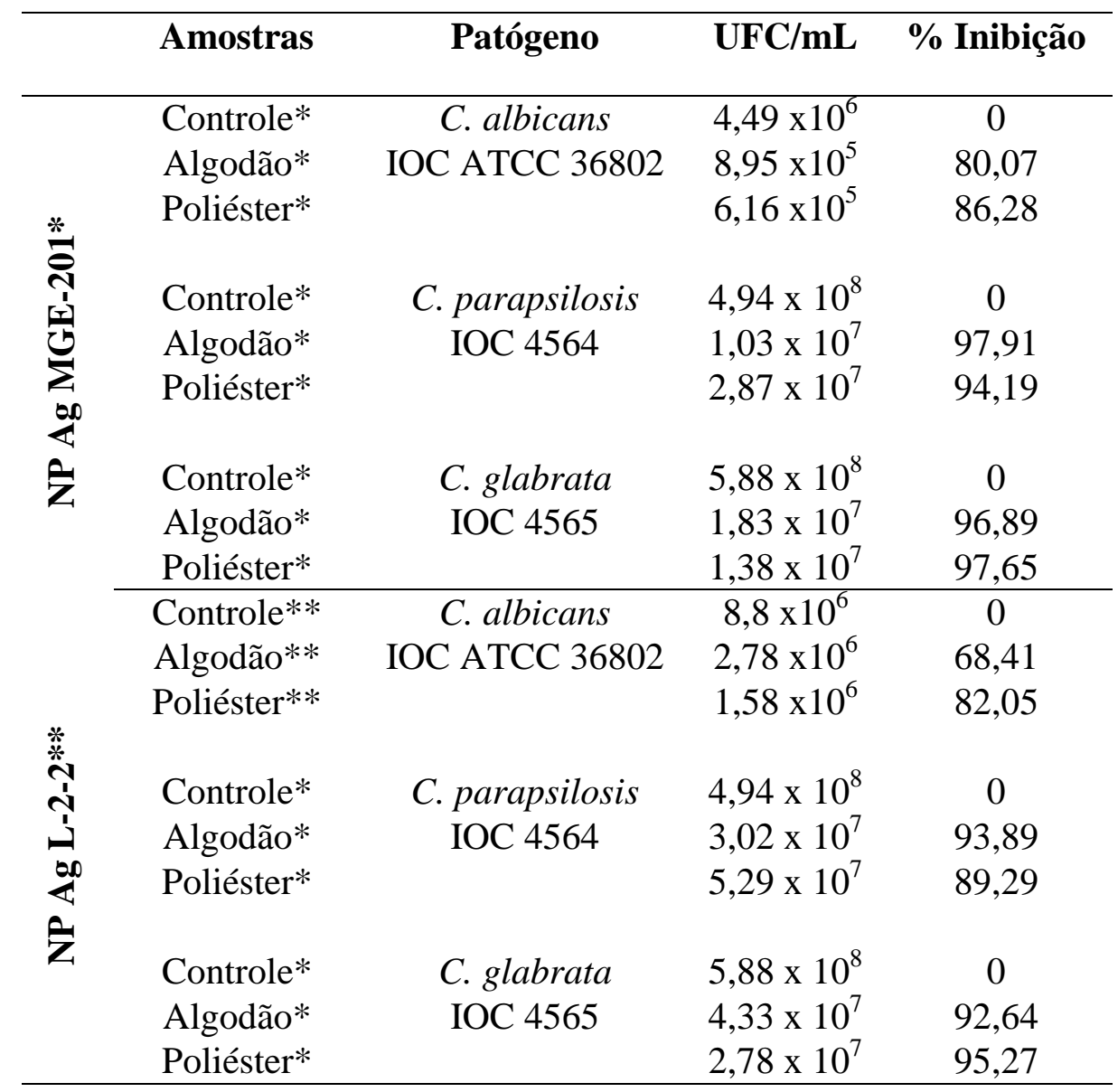

*Média de dois ensaios independentes em duplicata e ** média de um ensaio em duplicata. UFC $/ \mathrm{mL}=$ unidades formadoras de colônias/mL na suspensão de C. albicans ATCC 36802. \% NP Ag = \% NP Ag impregnadas no tecido. Controle $=$ Candida albicans ATCC 36802 sem tratamento.

\subsection{Teste de ação antibacteriana para tecidos impregnados com NP Ag}

Conforme apresentado na Tabela 9, os tecidos de algodão e poliéster impregnados por uma vez com nanopartículas de L-2-2 e de MGE-201 apresentaram efetiva inibição do crescimento das bactérias Gram-negativa (E. coli) e Gram-positiva ( $S$. aureus) e foram capazes de inibir em 100\% o crescimento dessas bactérias.

A concentração de prata reduzida nas dispersões de NP Ag antes dos processos de impregnação, medida por ICP, foi de $15,75 \mathrm{mg} / \mathrm{mL}$ e $19,3 \mathrm{mg} / \mathrm{mL}$ para L-2-2 e MGE-201, respectivamente. Como mostrado anteriormente as impregnações sobre algodão e poliéster por 1 vez, resultou em incorporação entre 0,1 e 6\% de NP L-2-2 e entre 2,7 e 9,9\% de NP Ag 
de MGE-201, respectivamente. Estes valores correspondem ao intervalo de 0,015 - 0,945 $\mu \mathrm{M}$ de NP em cada tecido para L-2-2 e 0,521-1,9107 $\mu \mathrm{M}$ de NP para MGE-201.

Os resultados de ação antimicrobiana mostram que as espécies de bactérias testadas foram mais sensíveis à ação das nanopartículas do que as espécies de Candida sp avaliadas.

Tabela 9 - Ação antibacteriana dos tecidos de poliéster e de algodão impregnados com as NP Ag de L-22 e MGE-201 sobre cepas clínicas de E. coli e $S$. aureus.

\begin{tabular}{lcccc}
\hline & $\begin{array}{c}\text { Concentração Ag } \\
(\mu \mathrm{g} / \mathbf{m L})\end{array}$ & $\begin{array}{c}\text { Concentração } \\
\text { do patógeno }(\mathbf{U F C} / \mathbf{m L})\end{array}$ & \% Inhibição \\
\hline Poliéster & & & $\boldsymbol{E}$. coli & S. aureus \\
NP Ag L-2-2 & $170 \mu \mathrm{g} / \mathrm{mL}$ & $1 \times 10^{5}$ & 100,0 & 100,0 \\
NP Ag MGE-201 & $170 \mu \mathrm{g} / \mathrm{mL}$ & $1 \times 10^{5}$ & 100,0 & 100,0 \\
\hline Algodão & & & & \\
NP Ag L-2-2 & $170 \mu \mathrm{g} / \mathrm{mL}$ & $1 \times 10^{5}$ & 100,0 & 100,0 \\
NP Ag MGE-201 & $170 \mu \mathrm{g} / \mathrm{mL}$ & $1 \times 10^{5}$ & 100,0 & 100,0 \\
\hline Controle positivo & - & & 0 & 0 \\
\hline
\end{tabular}

\subsection{Estudo da toxicidade das nanopartículas de prata}

As nanopartículas de MGE-201 e de L-2-2 foram relativamente tóxicas em macrófagos e pelo ensaio do MTT apresentaram $\mathrm{IC}_{50}$ - concentração na qual pelo menos $50 \%$ das células permanecem viáveis - de 5,5 e 26 e $\mu \mathrm{g} / \mathrm{mL}$, respectivamente. No entanto, o aumento das concentrações das NP Ag não ocasionou aumento da citotoxicidade. Os ensaios de MTT e DNA indicaram que as NP Ag de MGE-201 e de L-2-2 foram pouco tóxicas na concentração de $1.000 \mu \mathrm{g} / \mathrm{mL}$ apresentando viabilidade celular acima de $50 \%$ nesta concentração. 


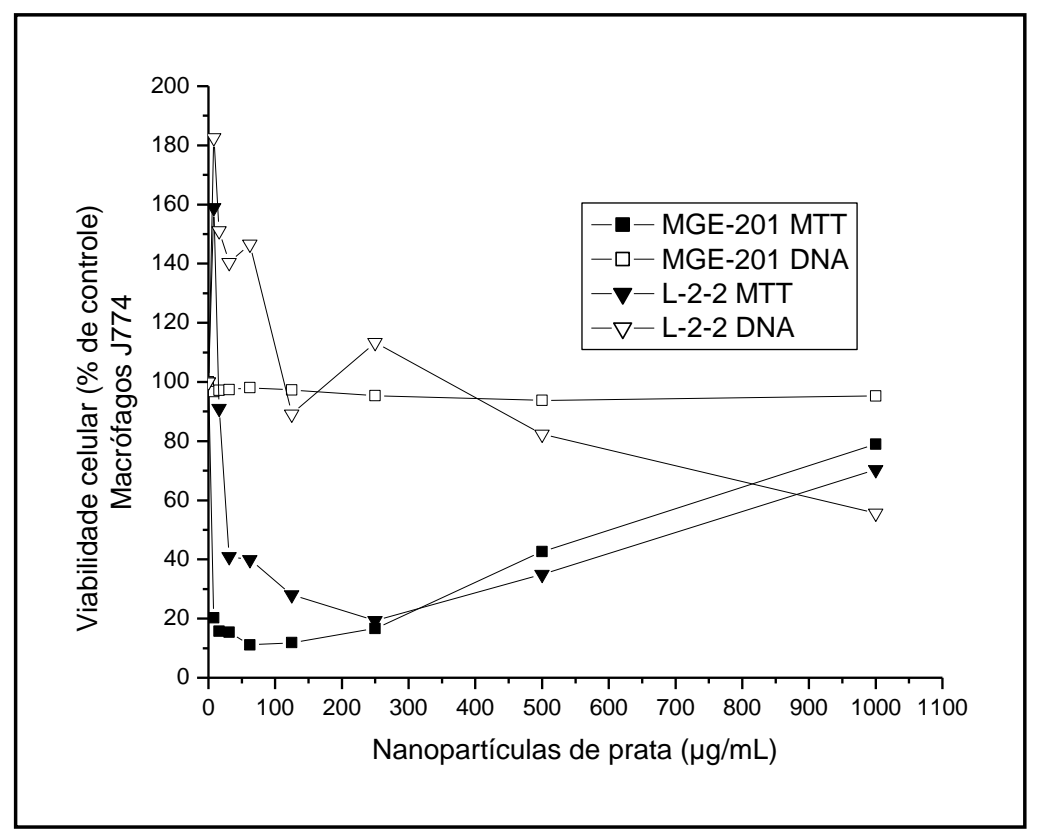

Figura 17 - Viabilidade celular de macrófagos tratados com nanopartículas de prata de L-2-2 e MGE201 nas concentrações de 8 a $1.000 \mu \mathrm{g} / \mathrm{mL}$ pelos ensaios de DNA e MTT. A concentração $\underline{0}$ (zero) refere-se a macrófagos tratados somente com meio de cultura DMEM. Média de dois ensaios independentes.

Hepatócitos de ratos foram tratados com as NP Ag de L-2-2 e de MGE-201 por 20 horas (Figura 13) e a Tabela 10 apresenta a estimativa dos valores de $\mathrm{IC}_{50}$.

Comparando-se hepatócitos tratados com as NP Ag em relação ao controle pode-se observar que pelo ensaio de DNA que avalia a manutenção da viabilidade e/ou a proliferação celular, o valor de $\mathrm{IC}_{50}$ foi de $420 \mu \mathrm{g} / \mathrm{mL}$ para as NP Ag de L-2-2. Na concentração de até $1.000 \mu \mathrm{g} / \mathrm{mL}$, a viabilidade dos hepatócitos foi mantida em 50 e 70 para as NP Ag de L-2-2 e MGE-201, respectivamente. 


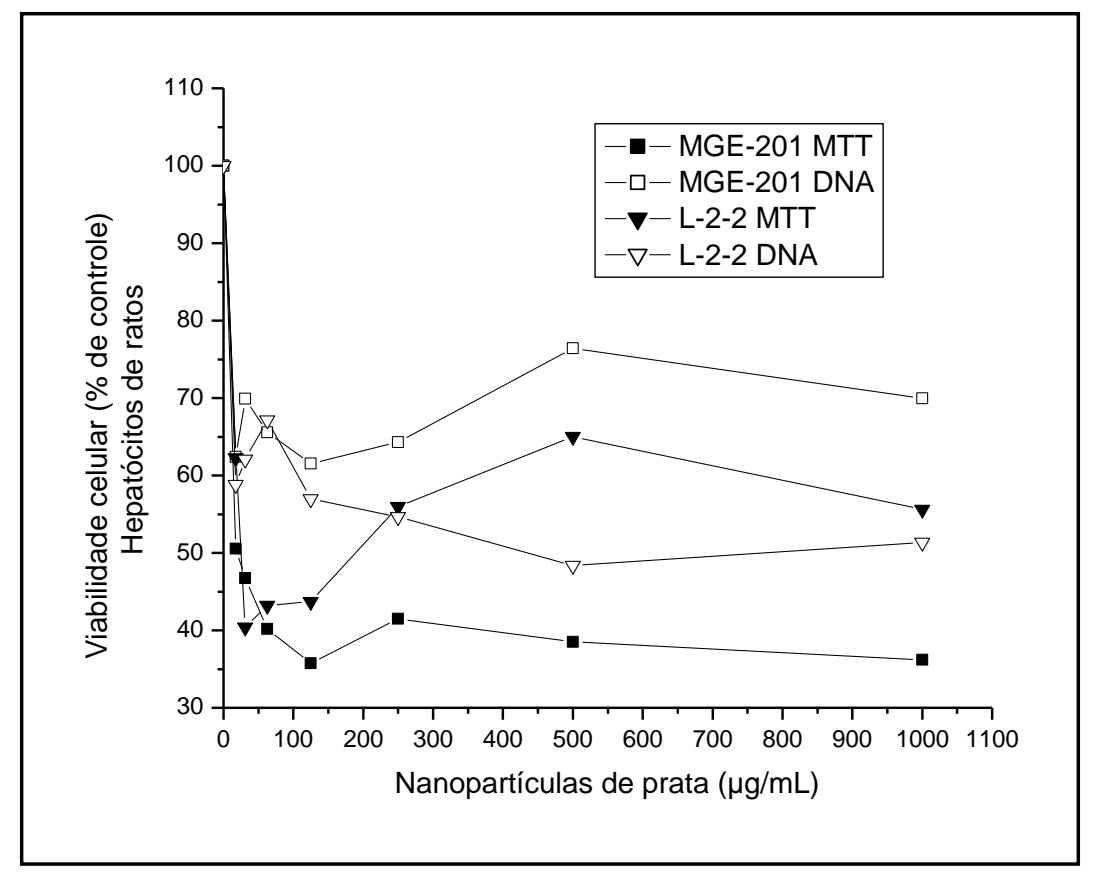

Figura 18 - Viabilidade celular de hepatócitos de ratos tratados com nanopartículas de prata de L-2-2 e MGE-201 nas concentrações de 8 a $1.000 \mu \mathrm{g} / \mathrm{mL}$ pelos ensaios de DNA e MTT. A concentração $\underline{0}$ (zero) refere-se a hepatócitos tratados somente com meio de cultura DMEM. Média de dois ensaios independentes.

Pelo ensaio de MTT, os valores de $\mathrm{IC}_{50}$ foram de 17 e $26 \mu \mathrm{g} / \mathrm{mL}$ para NP Ag de L-2-2 e MGE-201, respectivamente. No entanto, o aumento das concentrações das NP Ag não ocasionou acréscimo de citotoxicidade nos hepatócitos. As NP Ag de MGE-201e L-2-2 apresentaram viabilidade celular em torno de 40 e 50\%, respectivamente, na concentração de $1.000 \mu \mathrm{g} / \mathrm{mL}$ (Tabela 10). Estes dados indicam que estas NP Ag apresentam pouca interferência na atividade da enzima mitocondrial succinato desidrogenase e moderada citotoxicidade em hepatócitos que são células com capacidade de metabolização de xenobióticos.

Tabela 10 - Viabilidade celular $\left(\mathrm{IC}_{50}\right)$ de macrófagos $\mathrm{J} 774$ e hepatócitos de ratos tratados com as nanopartículas de prata de L-2-2 e MGE-201.

\begin{tabular}{lccc}
\hline & \multicolumn{2}{c}{ IC $_{\mathbf{5 0}}(\boldsymbol{\mu g} / \mathbf{m L})$} \\
\hline Nanopartículas de prata & MTT & DNA \\
\hline Macrófagos & L-2-2 & 5,5 & $>1.000$ \\
& MGE-201 & 26 & $>1.000$ \\
\hline Hepatócitos & L-2-2 & 26 & 420 \\
& MGE-201 & 17 & $<5$ \\
\hline
\end{tabular}




\section{CONCLUSÕES}

- Cinco linhagens de fungos foram eficazes na síntese de NP Ag e duas foram selecionados para continuidade do estudo;

- As NP Ag obtidas a partir de L-2-2, R-2BI-4 e MGE-201 foram caracterizadas por Microscopia Eletrônica de Transmissão, Espectroscopia de Correlação de Fótons e Espectrofotometria UVIVis;

- As NP Ag obtidas a partir de L-2-2 e MGE-201 apresentam relativa uniformidade de tamanho, sendo as NP Ag L-2-2 as mais uniformes;

- Os dados de TEM, Espectroscopia de Correlação de Fótons e a análise do gel SDSPAGE indicam a presença de proteínas na dispersão das NP Ag obtidas a partir do filtrado fúngico por L-2-2 e MGE-201;

- As NP Ag de L-2-2, R-2BI-4, MGE-201, MGE-202 e R-3BI-10 apresentaram ação antifúngica com CIMs de 1,2 a 44,6 $\mu \mathrm{mol} / \mathrm{L}$, sendo a ação antifúngica das NP Ag de MGE-201 > R-2BI-4 > L-2-2 > MGE-202 > R-3BI-10;

- A ação antibacteriana das NP Ag de MGE-201 apresentou melhores resultados que L-2-2, ambas com ação antibacteriana acima de $65 \%$ na concentração de $1,1 \mathrm{ug} / \mathrm{mL}$ e acime de $84 \%$ na concentração de $2,2 \mathrm{ug} / \mathrm{mL}$;

- Foi possível identificar nove proteínas presentes no FF e na dispersão de NP preparadas a partir do fungo MGE-201 por LC-MS;

- Emissão de Fluorescência e FTIR mostrou a presença de proteínas, tendo espectros de aminoácidos como evidencia no FF e nas dispersões de NP Ag;

- A incorporação de NP Ag em tecidos de algodão e poliéster esteve na faixa de 0,1 a $12,5 \%$, sendo que o tecido de algodão não apresentou proporção direta entre o número de impregnações e a porcentagem de incorporação de NP, enquanto que o tecido de poliéster mostrou resultados mais consistentes nesse aspecto;

- Em relação à impregnação das NP Ag de L-2-2 e MGE-201 em tecidos de algodão e poliéster não houve diferenças discrepantes entre o número de impregnações e a inibição de crescimento proporcionada, e que a impregnação de NP Ag em tecido de poliéster se mostra relativamente mais efetiva para inibir o crescimento de patógenos. 


\section{REFERÊNCIAS}

ACOSTA-TORRES, L. S.; LÓPEZ-MARÍN, L. M.; NÚÑEZ-ANITA, R. E.; HERNÁNDEZPADRÓN, G.; CASTAÑO, V. M. Biocompatible metal-oxide nanoparticles: nanotechnology improvement of conventional prosthetic acrylic resins. Journal of Nanomaterials, p. 1-8, 2011.

AGABEKOV, V.; IVANOVA, N.; DLUGUNOVICH, V.; VOSTCHULA, I. Optical properties of polyvinyl alcohol films modified with silver nanoparticles. Journal of Nanomaterials, v. 2012, p. 1-5, 2012.

AHAMED, M.; KARNS, M.; GOODSON, M.; ROWE, J.; HUSSAIN, S. M.; SCHLAGER, J. J.; HONG, Y. DNA damage response to different surface chemistry of silver nanoparticles in mammalian cells. Toxicology and Applied Pharmacology, v. 233, p. 404-410, 2008.

AHMAD, A.; MUKHERJEE, P.; SENAPATI, S.; MANDAL, D.; KHAN, M. I.; KUMAR, R.; SASTRY, M. Extracellular biosynthesis of silver nanoparticles using the fungus Fusarium oxysporum. Colloids and Surfaces B: Biointerfaces, v. 28, p. 313-318, 2003.

ALONGI, D. M. Carbon sequestration in mangrove forests. Review. Carbon Management, v. 3, n. 3, p. 313-322, 2012.

ALT, V.; BECHERTB, T.; STEINRÜCKEB, P.; WAGENERC, M.; SEIDELD, P.; DINGELDEIND, E.; DOMANNE, E.; SCHNETTLER, R. An in vitro assessment of the antibacterial properties and cytotoxicity of nanoparticulate silver bone cement. Biomaterials, v. 25, p. 4383-4391, 2004.

ANANDA, K.; SHRIDHAR, K. R. Diversity of filamentous fungi on decomposing leaf and woody litter of mangrove forests in the southwest coast of India. Current Sci., v. 87, p. 14311438, 2004.

ANDERSEN, M. M. Silent innovation: corporate strategizing in early nanotechnology. In: DRUD conference, Copenhagem, 2011. Anais... Copenhagem, 2011.

ANDREOTE, F. D.; JIME`NEZ, D. J.; CHAVES, D.; DIAS, A. C. F.; LUVIZOTTO, D. M.; et al. The microbiome of brazilian mangrove sediments as revealed by metagenomics. PLoS ONE, v. 7, n. 6, p. 1-14, 2012.

ANGELESCU, D. G.; MAGNO, L. M.; STUBENRAUCH, C. Monte Carlo simulation of the size and composition of bimetallic nanoparticles synthesized in water in oil microemulsions. J. Phys. Chem. C, v. 114, n. 50, p. 22069-22078, 2010.

ANO BOM, A.; FREITAS, M.; MOREIRA, D.; SANCHES, D.; GOMES, A.; VALENTE, A.; CORDEIRO, Y.; SILVA, J. The p53 core domain is a molten globule at low $\mathrm{pH}$ functional implications of a partially unfolded structure. The Journal of Biological Chemistry, v. 285, p. 2857-2866, 2010.

*De acordo com: ASSOCIAÇÃO BRASILEIRA DE NORMAS TÉCNICAS. NBR 6023: informação e documentação: referências: elaboração. Rio de Janeiro, 2002. 
ANTONY, J. J.; SIVALINGAM, P.; SIVA, D.; KAMALAKKANNAN, S.; ANBARASU, K.; SUKIRTHA R.; KRISHNAN, M.; ACHIRAMAN, S. Comparative evaluation of antibacterial activity of silver nanoparticles synthesized using Rhizophora apiculata and glucose. Colloids Surf. B, v. 88, p. 134-140, 2011.

ARAÚJO, W. L.; MACCHERONI, W. J.; AGUILAR-VILDOSO, C. I.; BARROSO, P. A. V.; SARIDAKIS, H. O.; AZEVEDO, J. L. Variability and interactions between endophytic bacteria and fungi isolated from leaf tissues of citrus rootstocks. Canadian Journal of Microbiology, v. 47, p. 229-236, 2001.

ARORA, S.; JAIN, J.; RAJWADE, J. M.; PAKNIKAR, K. M. Cellular responses induced by silver nanoparticles: in vitro studies. Toxicol. Lett., v. 179, p. 93-100, 2008.

ARYA, V. Living system eco-friendly nano factories. Digest. J. Nanomater. Biostruct., v. 5, p. 9-21, 2010.

ASHARANI, P. V.; WU, Y. L.; GONG, Z. Y.; VALIYAVEETTIL, S. Toxicity of silver nanoparticles in zebrafish models. Nanotechnology, v. 19, p. 1-8, 2008.

ASHARANI, P. V.; MUN, G. L. K.; HANDE, M. P.; VALIYAVEETTIL, S. Cytotoxicity and genotoxicity of silver nanoparticles in human cells. ASCNANO, v. 3, n. 2, p. 279-290, 2009.

BAKER, C.; PRADHAN, A.; PAKSTIS, L.; POCHAN, D. J.; SHAH, S. I. Synthesis and antibacterial properties of silver nanoparticles. J. Nanosci. Nanotechnol., v. 5, p. 244-249, 2005.

BALAJI, D. S.; BASAVARAJA, S.; DESHPANDE, R.; BEDRE MAHESH, D.; PRABHAKAR, B. K.; VENKATARAMAN. A. Extracellular biosynthesis of functionalized silver nanoparticles by strains of Cladosporium cladosporioides fungus. Colloids Surf. B, v. 68, p. 88-92, 2009.

BALAN, L.; SCHNEIDER, R.; TURCK, C.; LOUGNOT, D.; MORLET-SAVARY, F. Photogenerating silver nanoparticles and polymer nanocomposites by direct activation in the near infrared. Journal of Nanomaterials, v. 2012, p. 1-6, 2012.

BHAINSA, K. C.; D'SOUZA S. F. Extracellular biosynthesis of silver nanoparticles using the fungus Aspergillus fumigatus. Colloids Surf. B,v. 47, p. 160-164, 2006.

BILBERG, K.; HOVGAARD, M. B. R.; BESENBACHER, F.; BAATRUP, E. In vivo toxicity of silver nanoparticles and silver ions in zebrafish (Danio rerio). Journal of Toxicology, v. 2012, p. 1-9, 2012.

BILBERG, K.; MALTE, H.; WANG, T.; BAATRUP, E. Silver nanoparticles and silver nitrate cause respiratory stress in eurasian perch (Perca fluviatilis). Aquat. Toxicol., v. 96, n. 1, p. 159-165, 2010. 
BIRGE, W.; ZUIDERVEEN, J. The comparative toxicity of silver to aquatic biota. Proceedings, 3rd Argentum International. In: Conference on the transport, fate, and effects of silver in the environment. Anais... Washington, DC, 1995.

BRADFORD, M. A. A rapid and sensitive method for the quantification of microgram quantities of protein utilizing the principles of protein-dye binding. Analytical Biochemistry, v. 72, p. 248-254, 1976.

BRASIL. Ministério da Saúde. Conceitos e definições em saúde. 1977. Disponível em: <http://bvsms.saude.gov.br/bvs/publicacoes/0117conceitos.pdf>. Acesso em: 15 out. 2012.

BREATHNACH, A. S. Nosocomial infections. Medicine, v. 33, n. 3, p. 22-26, 2005.

BRUST, M.; WALKER, M.; BETHELL, D.; SCHIFFRIN, D. J.; WHYMAN, R. Synthesis of thiol-derivatised gold nanoparticles in a two-phase liquid-liquid system. Chem. Commun., v. 7, p. 801-802, 1994.

BULET, P.; DINAMARQ, J. L.; HETRU, C.; LAGUEUX, M.; CHARLET, M.; HEGY, G.; DORSSELAER, A. V.; HOFFMANN, J. A. A novel inducible antibacterial peptide of Drosophila carries an o-glycosylated substitution. J. Biol. Chem., v. 268, p. 14893-14897, 1993.

CASTELLANI, A. A maintenance and cultivation of the common pathogenic fungi of man in sterile distilled water. Further researches. Jour. Trop. Med. Hyg., v. 70, p. 181-184, 1967.

CASTRO-LONGORIA, E.; VILCHIS-NESTOR, A. R.; AVALOS-BORJA, M. Biosynthesis of silver, gold and bimetallic nanoparticles using the filamentous fungus Neurospora crassa. Colloids Surf. B., v. 83, p. 42-48, 2011.

CHEN, M.; GOODMAN, D. W. Catalytically active gold: from nanoparticles to ultrathin films. Acc. Chem. Res., v. 39, p. 739-746, 2006.

CHEN, S.; TEMPLETON, A. C.; MURRAY, R. W. Monolayer-protected cluster growth dynamics. Langmuir, v. 16, p. 3543-3548, 2000.

CHEN, X.; LIU, L.; LIU, Z.; MARCUS, M. A.; WANG, WEI-CHENG.; OYLER, N. A.; GRASS, M. E.; MAO, B.; GLANS, PER-ANDERS.; YU, P. Y.; GUO, J.; MAO S. S. Properties of disorder-engineered black titanium dioxide nanoparticles through hydrogenation. Nature, v. 3, n. 1510, p. 1-7, 2013.

CHOI, O.; DENG K. K.; KIM, NAM-JUNG.; ROSS JR, L.; SURAMPALLI, R. Y.; HU, Z. The inhibitory effects of silver nanoparticles, silver ions, and silver chloride colloids on microbial growth. Water Research, v. 42, p. 3066-3074, 2008.

CHOI, O.; HU, Z. Q. Size dependent and reactive oxygen species related nanosilver toxicity to nitrifying bacteria. Environ. Sci. Technol., v. 42, n. 458, p. 3-8, 2008. 
CINGI, M. R.; DE ANGELIS， I.; FORTUNATI， E.; REGGIANI， D.; BIANCHI, V.; TIOZZO, R.; ZUCCO, F. Choice and standardization of test protocols in cytotoxicology: a multicentre approach. Toxicol. In Vitro, v. 5, n. 2, p. 119-125, 1991.

CLEARY, D. F. R.; SMALLA, K.; MENDONÇA-HAGLER, L. C. S.; GOMES, N. C. M. Assessment of variation in bacterial composition among microhabitats in a mangrove environment using DGGE fingerprints and barcoded pyrosequencing. PLoS One, v. 7, n. 1, p. $1-8,2012$

CLINICAL AND LABORATORY STANDARDS INSTITUTE (CLSI). Norma M27-A2. Método de referência para testes de diluição em caldo para determinação da sensibilidade de leveduras a terapia antifúngica. 2. ed. Pennsylvania/EUA: Edição Wayne, 2002. v. 22, n. 15, 45 p.

COSTA, I. P. M. W.; MAIA, L. C.; CAVALCANTI M. A. Diversity of leaf endophytic fungi in mangrove plants of northeast brazil. Brazilian Journal of Microbiology, p. 1165-1173, 2012.

COUTINHO, A. P. R.; DE MORAES, L. A.; BARATA, L. E.; DE SOUZA, A. O. Effects of the antimycobacterial compound 2-phenoxy-1-phenylethanone on rat hepatocytes and formation of metabolites. Pharm. Biol., v. 50, n. 10, p. 1317-1325, 2012.

CROUSE, H. F.; DOUDT, A.; ZERBE, C.; BASU, S. Detection of quadruplex DNA by gold nanoparticles. Journal of Analytical Methods in Chemistry, v. 2012, n. 2012, p. 1-7, 2012.

CUENYA, B. R. Synthesis and catalytic properties of metal nanoparticles: Size, shape, support, composition, and oxidation state effects. Thin Solid Films, v. 518, p. 3127-3150, 2010.

DA LUZ C. F. P.; BARTH, O. M. Pollen analysis of honey and beebread derived from brazilian mangroves. Brazilian Journal of Botany, v. 35, n. 1, p. 79-85, 2012.

DAHL, J.; MADDUX, B. L S.; HUTCHISON, J. E. “Toward greener nanosynthesis”. Chem. Rev., v. 107, p. 2228-2269, 2007.

DANIELS, J. K.; CHUMANOV, G. Spectroelectrochemical studies of plasmon coupled silver nanoparticles. J. Electroanal. Chem., v. 575, p. 203-209, 2005.

DE LIMA, B.; GILMA, N.; GALVANI, E. Mangrove microclimate: a case study from southeastern Brazil. Earth Interact., v. 17, p. 1-16, 2013.

DE LIMA, R.; SEABRA, A. B.; DURÁN, N. Silver nanoparticles: a brief review of cytotoxicity and genotoxicity of chemically and biogenically synthesized nanoparticles. J. Appl. Toxicol., v. 32, n. 11, p. 867-879, 2012.

DE SOUZA, A. O.; PEDROSA, M. T.; ALDERETE, J. B.; CRUZ, A. F.; PRADO, M. A.; ALVES, R. B.; SILVA, C. L. Cytotoxicity, antitumoral and antimycobacterial activity of tetrazole and oxadiazole derivatives. Pharmazie, v. 60, p. 396-397, 2005.

DEBYE, P. Der Lichtdruck auf Kugeln von beliebigem Material. Annalen der Physik, Vierte Folge, v. 30, n. 1, p. 57-136, 1909. 
DELABIE, J. H. C.; PAIM, V. R. L. M.; NASCIMENTO, I. C.; CAMPIOLO, S.; MARIANO, C. S. F. Ants as biological indicators of human impact in mangroves of the southeastern coast of Bahia, Brazil. Neotropical Entomology, v. 35, n. 5, p. 602-615, 2006.

DENIZOT, F.; LANG, R. Rapid colorimetric assay for cell growth and survival modifications to the tetrazolium dye procedure giving improved sensitivity and reliability. Journal of Immunological Methods, v. 89, p. 271-277, 1986.

DIAS, A. C. F.; ANDREOTE, F. D.; RIGONATO, J.; FIORE, M. F.; MELO, I. S.; ARAÚJO, W. L. The bacterial diversity in a Brazilian non-disturbed mangrove sediment. Antonie van Leeuwenhoek (Gedrukt), v. 98, p. 541-551, 2010.

DISCH， S.; WETTERSKOG， E.; HERMANN， R. P.; KOROLKOV， D.; BUSCH, P.; BOESECKE, P.; LYON, O.; VAINIO, U.; SALAZAR-ALVAREZ， G.; BERGSTRÖM, L.; BRÜCKEL, T. Structural diversity in iron oxide nanoparticle assemblies as directed by particle morphology and orientation. Nanoscale, v. 5, n. 9, p. 3969-75, 2013.

DOURADO, M. N.; FERREIRA, A.; ARAÚJO, W. L.; AZEVEDO, J. L.; LACAVA, P. T. The diversity of endophytic methylotrophic bacteria in an oil-contaminated and an oil-free mangrove ecosystem and their tolerance to heavy metals. Biotechnology Research International, v. 2012, p. 1-8, 2012.

DURÁN, N.; MARCATO, P. D.; ALVES, O, L.; DE SOUZA, G, I, H. Cellular oxidoreductive proteins of Chlamydomonas reinhardtii control the biosynthesis of silver nanoparticles. J. Nanopart., v. 3, p.1-7, 2005.

DURÁN, N.; MARCATO, P. D.; DE SOUZA, G. I. H.; ALVES, O. L.; ESPOSITO, E. Antibacterial effect of silver nanoparticles produced by fungal process on textile fabrics and their effluent treatment J. Biomedicine Nanotechnol., v. 3, p. 203-208, 2007.

DURÁN, N.; MARCATO, P. D.; INGLE, A.; GADE, A.; RAI, M. Fungi-mediated synthesis of silver nanoparticles: characterization processes and applications. Prog. Mycol., p. 425-449, 2010 .

EDISON, T. J. I.; SETHURAMAN, M. G. Instant green synthesis of silver nanoparticles using Terminalia chebula fruit extract and evaluation of their catalytic activity on reduction of methylene blue. Process Biochemistry, v. 47, p. 1351-1357, 2012.

EFTINK, M. R.; GHIRON, C. A. Fluorescence quenching studies with proteins. Analytical Biochemistry, v. 114, p. 199-227. 1981.

EISLER, R. Silver hazards to fish, wildlife, and invertebrates: A synoptic review. Contaminant Hazard Reviews, Report 32, Pautuxent Wildlife Research Center. US Geological Survey, Reston VA, 63, 1996. p. 1-44.

EKLUND, S. E.; CLIFFEL, D. E. Synthesis and catalytic properties of soluble platinum nanoparticles protected by a thiol monolayer. Langmuir, v. 20, n. 14, p. 6012-6018, 2004.

EL-NOUR, K. M. M. A.; EFTAIHA, A.; AL-WARTHAN, A.; AMMAR, R. A. A. Synthesis and applications of silver nanoparticles. J. Chem., v. 3, p. 135-140, 2010. 
EL-RAFIE, M. H.; MOHAMED, A. A.; SHAHEEN, TH. I.; HEBEISH, A. Antimicrobial effect of silver nanoparticles produced by fungal process on cotton fabrics. Carbohyd. Polym., v. 80, p.779-782, 2010.

EVANOFF JR. D. D.; CHUMANOV, G. Synthesis and optical properties of silver nanoparticles and arrays. ChemPhyChem., v. 6, p. 1221-1231, 2005.

FABREGA, J.; LUOMA, S. N.; TYLER, C. R.; GALLOWAY, T. S.; LEAD, J. R. Silver nanoparticles: behaviour and effects in the aquatic environment. Environment International, v. 37, p. 517-531, 2011.

FARADAY, M. The bakerian lecture: experimental relations of gold (and other metals) to light. Philos. Trans. R. Soc. London, v. 147, p. 145-181, 1857.

FARIA, A. F.; MARTINEZ, D. S. F. T.; MORAES, A. C. M.; DA COSTA, M. E. H. M.; BARROS, E. B., FILHO, A. G. S.; PAULA, A. J.; ALVES O. L. Unveiling the role of oxidation debris on the surface chemistry of graphene through the anchoring of $\mathrm{Ag}$ nanoparticles. Chem. Mater., v. 24, p. 4080-4087, 2012.

FERREIRA, T. O.; OTERO, X. L.; SOUZA-JUNIOR, V. S.; VIDAL-TORRADO, P.; MACÍAS, F.; ET AL. Spatial patterns of soil attributes and components in a mangrove system in Southeast Brazil (São Paulo). J. Soils. Sed., v. 10, n. 6, p. 995-1006, 2010.

FEYNMAN, R. There's plenty of room at the bottom. Engineering and Science, v. 23, p. 22-36, 1960.

FOLDBJERG, R.; DANG, D. A.; AUTRUP, H. Cytotoxicity and genotoxicity of silver nanoparticles in the human lung cancer cell line, A549. Arch.Toxicol., v. 85, p. 743-750, 2011.

FUKUDA, H.; LEE, J.; IMANAKA, Y. J. Variations in analytical methodology for estimating costs of hospital-acquired infections: a systematic review. Hospital Infection. v. 77, p. 93-105, 2011.

GADE, A.; BONDE, P.; INGLE, A. P.; MARCATO, P. D.; DURÁN, N.; RAI, M. K. Exploitation of Aspergillus niger for Synthesis of Silver Nanoparticles. J. Biobases Mat. Bioenerg., v. 2, p. 243-247, 2008.

GAJBHIYE, M.; KESHARWANI, J.; INGLE, A.; GADE, A.; RAI, M. Fungus-mediated synthesis of silver nanoparticles and their activity against pathogenic fungi in combination with fluconazole. Nanomed., v. 5, p. 382-386, 2009.

GARCÍA, C. P.; SUMBAYEV, V.; GILLILAND, D.; YASINSKA, I. M.; GIBBS B. F.; MEHN, D.; CALZOLAI, L.; ROSSI F. Microscopic analysis of the interaction of gold nanoparticles with cells of the innate immune system. Nature, v. 3, n. 1326, p. 1-7, 2013.

GASPAR, D.; PIMENTEL, A. C.; MATEUS, T.; LEITÃO, J. P.; SOARES, J.; FALCÃO, B. P.; ARAÚJO, A.; VICENTE, A.; FILONOVICH, S. A.; AGUAS, H.; MARTINS, 
R.; FERREIRA, I. Influence of the layer thickness in plasmonic gold produced by thermal evaporation. Sci. Rep., v. 3, n. 3, p. 1-5, 2013.

nanoparticles

GATTER, N.; KOHNEN, W.; JANSEN, B. In vitro efficacy of a hydrophilic central venous catheter loaded with silver to prevent microbial colonization. Zent. bl. Bakteriol., v. 287, p. 157-169, 1998.

GAYATHRI, S.; SARAVANAN, D.; RADHAKRISHNAN, M.; BALAGURUNATHAN, R.; KATHERISAN, K. Bioprospecting potencial of fast growing endophytic bacteria from leaves of mangrove and salt-marsh plant species. Indian Journal of Biotechnology, v. 9, p. 379402, 2010.

GIBBONS, B.; WARNAR, L. The role of antimicrobial silver nanotechnology. Medical Device and Diagnostic Industry Magazine. Aug 2005. Disponível em: <http://www.devicelink.com/>. Acesso em: 10 mar. 2013.

GOHARSHADI, E. K.; AZIZI-TOUPKANLOO, H. Silver colloid nanoparticles: ultrasoundassisted synthesis, electrical and rheological properties. Powder Technology, p. 1-29, 2012.

GOLE, A.; DASH, C.; RAMAKRISHNAN, V.; SAINKAR, S. R.; MANDALE, A. B.; RAO, M.; SASTRY, M. Pepsin-gold colloid conjugates: preparation, characterization, and enzymatic activity. Langmuir, v. 17, p. 1674-1679, 2001.

GOMES-FILHO, J. E.; SILVA, F. O.; WATANABE, S.; CINTRA, L. T. A.; TENDORO, K. V.; DALTO, L. G.; PACANARO, S. V.; LODI, C. S.; DE MELO, F. F. F. Tissue reaction to silver nanoparticles dispersion as an alternative irrigating solution. JOE, v. 36, n. 10, p. 1698$1702,2010$.

GOMES, A. M. A.; MARIANO, R. L. R.; MICHEREFF, S. J.; SILVEIRA, E. B.; ASSIS, S. M. P. Isolamento de bactérias para testes de antagonismo. In: MARIANO, R. L. R.; SILVEIRA, E. B. (Ed.). Manual de práticas em fitobacteriologia. 2. ed. Recife: Universidade Federal Rural de Pernambuco, 2005. p. 119-125.

GONZÁLEZ-MENDOZA， D.; ARGUMEDO-DELIRA， R.; MORALES-TREJO, A.; PULIDOHERRERA, A.; CERVANTES-DÍAZ, L.; GRIMALDO-JUAREZ, O.; ALARCÓN, A. A rapid method for isolation of total DNA from pathogenic filamentous plant fungi. Genet. Mol. Res., v. 9, p. 162-166, 2010.

GREEN, M. A.; PILLAI, S. Harnessing plasmonics for solar cells. Nature Photonics. v. 6, p. 130-131, 2012.

GROSELL, M.; DE BOECK, G.; JOHANNSSON, O.; WOOD, C. M. The effects of silver on intestinal ion and acid-base regulation in the marine teleost fish, Papophrys vetulus. Comp Biochem Physiol C. Toxicol. Pharmacol., v. 124, n. 2, p. 59-70, 1999.

GULRAJANI, M. L.; GUPTA, D.; PERIYASAMY, S.; MUTHU, S. G. Preparation and application of silver nanoparticles on silk for imparting antimicrobial properties. J. Appl. Polym. Sci., v. 108, p. 614-623, 2007. 
GUU, JR.; JU, Y. M.; HSIEH, H. J. Bionectriaceous fungi collected from forests in Taiwan. Botanical Studies, v. 51, p. 61-74, 2010.

HACKENBERG, S.; SCHERZED, A.; KESSLER, M.; HUMMEL, S.; TECHNAU, A.; FROELICH, K.; GINZKEY, C.; KOEHLER, C.; HAGEN, R.; KLEINSASSER, N. Silver nanoparticles: evaluation of DNA damage, toxicity and functional impairment in human mesenchymal stem cells. Toxicology Letters, v. 201, p. 27-33, 2011.

HANSON, J. R. The chemistry of fungi. Brighton: RSC Publishing, 2008. p. 1.

HARUTA, M. Size- and support-dependency in the catalysis of gold. Catal. Today, v. 36 p. 153-166, 1997.

HEATH, J. R. Size dependent surface-plasmon resonances of bare silver particles. Physical Review, v. 40, n. 4, p. 9982-9985, 1989.

HERZING, A. A.; KIELY, C. J.; CARLEY, A. F.; LANDON, P.; HUTCHINGS, G. J. Identification of active gold nanoclusters on iron oxide supports for $\mathrm{CO}$ oxidation. Science, v. 321, p. 1331-1335, 2008.

HOLGUIN, G.; VAZQUEZ, P.; BASHAN, Y. The role of sediment microorganisms in the productivity, conservation, and rehabilitation of the mangrove ecosystems: an overview. Biol. Fertil. Soils, v. 33, p. 265-278, 2001.

HUANG, H. B.; XIAO, Z. E.; FENG, X. J.; HUANG, C. H.; ZHU, X.; JU, J. H.; LI, M. F.; LIN, Y. C.; LIU, L.; SHE, Z. G. Cytotoxic naphtho-g-pyrones from the mangrove endophytic fungus Aspergillus tubingensis (GX1-5E). Helv. Chim. Acta, v. 94, p.1732-1740, 2011a.

INGLE, A.; GADE, A.; BAWASKAR M.; RAI, M. Fusarium solani: A novel biological agent for the extracellular synthesis of silver nanoparticles, Journal of Nanoparticle Research., v. 11, p. 2079-2085, 2009.

INTELLECTUAL PROPERTY OFFICE (IPO). UK innovation nanotechnology patent landscape analysis. 2009.

JAIN, P.; PRADEEP, T. Potential of silver nanoparticle-coated polyurethane foam as an antibacterial water filter. Biotechnology and Bioengineering, v. 90, n. 1, p. 59-63, 2005.

JANA, N. R.; GEARHEART, L.; MURPHY, C. J. Seed-mediated growth approach for shapecontrolled synthesis of spheroidal and rod-like gold nanoparticles using a surfactant template. Adv. Mater., v. 13, n. 18, p. 1389-1393, 2001.

JEBALI, A.; RAMEZANI, F.; KAZEMI, B. Biosynthesis of silver nanoparticles by Geotricum sp. J. Cluster Sci., v. 22, p. 225-232, 2011.

JEYARAJ, M.; RAJESHA, M.; ARUNB, R.; ALIC, D. M.; SATHISHKUMARA, G.; SIVANANDHANA, G.; DEVA, G. K.; MANICKAVASAGAMA, M.; PREMKUMARB, K.; THAJUDDINC, N.; GANAPATHIA, A. An investigation on the cytotoxicity and caspasemediated apoptotic effect of biologically synthesized silver nanoparticles using Podophyllum 
hexandrum on human cervical carcinoma cells. Colloids and Surfaces B: Biointerfaces, v. 102 p. $708-717,2013$.

JIANG, H.; MANOLACHE, S.; WONG, A. C. L.; DENES, F. S. Plasma-enhanced deposition of silver nanoparticles onto polymer and metal surfaces for the generation of antimicrobial characteristics. Journal of Applied Polymer Science, v. 93, p. 1411-1422, 2004.

JIANG, W.; MASHAYEKHI, H.; XING, B. Bacteria toxicity comparison between nano- and micro-scaled oxide particles. Environ. Pollut., v. 157, p. 1619-1625, 2009.

JORDAN, C. C.; KAISER, I. N.; MOORE, V. C. Nanotechnology patent survey: who will be the leaders in the fifth technology revolution?. Nanotechnology Law \& Business, p. 122$132,2012$.

KABASHIN, A. V.; DELAPORTE, A. P.; GROJO, D.; TORRES R.; SENTIS, T. S. M. Nanofabrication with pulsed lasers. Nanoscale Research Letters , v. 5, p. 454-463, 2010

KAEGI, R.; SINNET, B.; ZULEEG, S.; HAGENDORFER, H.; MUELLER, E.; VONBANK, R.; BOLLER, M.; BURKHARDT, M. Release of silver nanoparticles from outdoor facades. Environmental Pollution, v. 158, p. 2900-2905, 2010.

KANG, S. W.; CHAR, K.; K.; KANG, Y. S. Novel application of partially positively charged silver nanoparticles for facilitated transport in olefin/paraffin separation membranes. Chem. Mater., v. 20, p. 1308-1311, 2008.

KATHIRESAN, K.; ALIKUNHI, N. M.; PATHMANABAN, S.; NABIKHAN, A.; KANDASAMY, S. Analysis of antimicrobial silver nanoparticles synthe-sized by coastal strains of Escherichia coli and Aspergillus niger. Can. J. Microbiol., v. 56, p. 1050-1059, 2010.

KATHIRESAN, K.; BINGHAM, B. L. Biology of mangroves and mangrove ecosystems. Advances in Marine Biology, v. 40, p. 81-251, 2001.

KATHIRESAN, K.; MANIVANNAN, S.; NABEEL, M. A.; DHIVYA B. Studies on silver nanoparticles synthesized by a marine fungus, Penicillium fellutanum isolated from coastal mangrove sediment. Colloids Surf. B., v. 71, p. 133-137, 2009.

KERKER, M. The scattering of light and other electromagnetic radiation. London: Academic Press, 1969.

KHAN, S. S.; MUKHERJEE, A.; CHANDRASEKARAN, N. Studies on interaction of colloidal silver nanoparticles (SNPs) with five different bacterial species. Colloids Surf. B Biointerfaces, v. 87, p. 129-138, 2011.

KIM, J. S.; KUK, E.; YU, K. N.; KIM, J. H.; PARK, S. J.; LEE, H. J. Antimicrobial effects of silver nanoparticles. Nanomed. Nanotechnol. Biol. Med., v. 3, p. 95-101, 2007.

KIM, Y. S.; SONG, M. Y.; PARK, J. D.; SONG, K. S.; RYU, H. R.; CHUNG, Y. H.; CHANG, H. K.; LEE, J. H.; OH, K. H.; KELMAN, B. J.; HWANG, I. K.; YU, I. J. 
Subchronic oral toxicity of silver nanoparticles. Particle and Fibre Toxicology, v. 7, n. 20, p. $1-11,2010$.

KIM, Y.; SUH, H. S.; CHA, H. J.; KIM, S. H.; JEONG, K. S.; KIM, D. H. A case of generalized argyria after ingestion of colloidal silver solution. Am. J. Ind. Med., v. 52, p. 246-250, 2009.

KIMURA, M. A simple method for estimating evolutionary rates of base substitutions through comparative studies of nucleotide sequences. J. Mol. Evol., v. 16, p. 111-120, 1980.

KLASEN, H. J. Historical review of the use of silver in the treatment of burns. I. Early uses. Burns., v. 26, p. 117-130, 2000.

KOKURA, S.; HANDA, O.; TAKAGI, T.; ISHIKAWA, T.; NAITO, Y.; YOSHIKAWA, T. Silver nanoparticles as a safe preservative for use in cosmetics. Nanomedicine: Nanotechnology, Biology, and Medicine, v. 6, p. 570-574, 2010.

KOMIYAMA, A.; ONG, J. E.; POUNGPARN, S. Allometry, biomass and productivity of mangrove forests: a review.Aquatic Botany, v. 89, n. 2, p. 128-137, 2008.

KOWSHIK, M.; ASHTAPUTRE, S.; KHARRAZI, S.; VOGEL, W.; URBAN, J.; KULKARANI, S. K.; PAKNIKAR, K. M. Extracellular synthesis of silver nanoparticles by a silver-tolerant yeast strain MKY3. Nanotechnology, v. 14, p. 95-100, 2003.

KREIBIG, U.; SCHMITZ, B.; BREUER, H. D. Separation of plasmon-polariton modes of small metal particles. Physical Review B, v. 36, n. 9, 1987.

KREIBIG, U.; VOLLMER, M. Optical Properties of Metal Clusters. Springer: New York, Chapter 2, 1995.

KRUTYAKOV, Y. A.; KUDRINSKIY, A. A.; OLENIN, A. Y.; LISICHKIN, G. V. Synthesis and properties of silver nanoparticles: advances and prospects. Russian Chemical Reviews, v. 77, n. 3, p. 233-257, 2008.

KVITEK, L.; VANICKOVA, M.; PANACEK, A.; SOUKUPOVA, J.; DITTRICH, M.; VALENTOVA, E. Initial study on the toxicity of silver nanoparticles (nps) against Paramecium caudatum. J. Phys. Chem. C., v. 113, n. 4, p. 296-300, 2009.

LAKOWICZ, J. R. Principles of fluorescence spectroscopy. New York: Plenum Press, $1983.510 \mathrm{p}$.

LANKVELD, D. P. K.; OOMENB, A. G.; KRYSTEK, P.; NEIGH, A.; DE JONG, A. T.; NOORLANDER, C.W.; VAN EIJKEREN, J. C. H.; GEERTSMA, R. E.; DE JONG, W.H. The kinetics of the tissue distribution of silver nanoparticles of different sizes. Biomaterials, v. 31, p. 8350-8361, 2010. 
LEE, HYO-JEOUNG.; SONG, J. Y.; KIM, B. S. Biological synthesis of copper nanoparticles using Magnolia kobus leaf extract and their antibacterial activity. Journal of Chemical Technology and Biotechnology, n. 88, p. 1971-1977, 2013.

LESLIE, J. F.; K. K. KLEIN. Female fertility and mating-type effects on effective population size and evolution in filamentous fungi. Genetics, v. 144, p. 557-567, 1996.

LI, G. Q.; HUANG, H. C.; KOKKO, E. G.; ACHARYA, S. N. Ultrastructural study of mycoparasitism of Gliocladium roseum on Botrytis cinerea. Botanical Bulletin of Academia Sinica, Taiwan, v. 43, n. 2, p. 211-218, 2002.

LI, W.; XIAO, Y.; WANG, C.; DANG, J.; CHEN, C.; GAO, L.; BATZER, J. C.; SUN, G.; GLEASON, M. L. A new species of Devriesia causing sooty blotch and flyspeck on Rubber Trees in China. Mycol. Progress, p. 1-6, 2013.

LIU, Q.; XU, Z.; FINCH, J. A.; EGERTON, R. A novel two-step silica-coating process for engineering magnetic nanocomposites. Chem. Mater., v. 10, p. 3936-3940, 1998.

LIU, S. H.; ZHANG, Z. H.; HAN, M. Y. Gram-scale synthesis and biofunctionalization of silica-coated silver nanoparticles for fast colorimetric DNA detection. Anal. Chem., v. 77, p. 2595-2600, 2005.

LIU, Y. J.; WHELEN, S.; HALL, B. D. Phylogenetic relationships among ascomycetes: evidence from an RNA polymerse II subunit. Mol. Biol. Evol., v. 16, n. 12, p. 1799-1808, 1999.

LORENZ, L. Sur la lumière réfléchie et réfractée par une sphère (surface) transparente. in Oeuvres scientifiques de L. Lorenz. revues et annotées par H. Valentiner. Tome Premier. Libraire Lehmann \& Stage, Copenhague, p. 403-529, 1898.

LOWRY, O. H.; ROSEBROUGH, N. J.; FARR, A. L.; RANDALL, R. Protein measurement with the folin-phenol reagents. J. Biol. Chem., v. 193, p. 265-275, 1951.

LUBICK, N. Ceramic filter makes water treatment easy. Environmental Science and Technology, v. 42, p. 649-650, 2008.

LUOMA, S. N. Silver nanotechnologies and the environment: old problems or new challenges?. Woodrow Wilson International Center for Scholars, p. 9-66, 2008.

MAALI, A.; CARDINAL, T.; TREGUER-DELAPIERRE, M. Intrinsic fuorescence from individual silver nanoparticles. Physica E, v. 17, p. 559-560, 2003.

MACDONALD, I. D. G, SMITH, W. E. Orientation of cytochrome c adsorbed on a citratereduced silver colloid surface. Langmuir, v. 12, p. 706-713. 1996.

MACHADO, A.; FERRAZ, A. A. B.; FERRAZ, E.; ARRUDA, E.; NOBRE, J.; KONKEWICZ, L. R.; PIMENTEL, M. L.; LEÃO, M. T. C.; TRABASSO, P.; GRIMBAUM, R. Prevenção da infecção hospitalar. Sociedade Brasileira de Infectologia, 2001. Disponível em: 〈http://www.bibliomed.com.br/diretrizes/pdf/infeccao_hospitalar.pdf>. Acesso em: 15 out. 2011. 
MALUCHE, M. E.; SANTOS, J. I. Candida sp. and nosocomial infections: epidemiological and laboratory aspects. Rev. Bras. Anál. Clín., v. 40, p. 65-67, 2008.

MANDAL, S.; PHADTARE, S.; SASTRY, M. Interfacing biology nanoparticles. Current Applied Physics, v. 5, p. 118-127, 2005.

MARTINS, P. T. A.; COUTO, E. C. G.; DELABIE, J. H. C. Phytosociology of the cururupe river mangrove (Ilhéus, Bahia State, Brazil). Journal of Integrated Coastal Zone Management, v. 11, n. 2, p. 163-169, 2011.

MAYFIELD, D. A.; KARAKAYA, A.; BATZER, J. C.; BLASER, J. M.; GLEASON, M. L. Diversity of sooty blotch and flyspeck fungi from apples in northeastern Turkey. Eur. J. Plant. Pathol., v. 135, p. 805-815, 2012.

MERIN, D. D.; PRAKASH, S.; BHIMBA, B. V. Antibacterial screening of silver nanoparticles synthesized by marine micro algae. Asi. Pac. Trop. Med., p. 797-799, 2010.

MENDES, L. W.; TAKETANI, R. G.; NAVARRETE, A. A.; TSAI S. M. Shifts in phylogenetic diversity of archaeal communities in mangrove sediments at different sites and depths in southeastern Brazil. Research in Microbiology, v. 163, p. 366-377, 2012.

MIAO, A-J.; SCHWEHR, K. A.; XU, C.; ZHANG, S-J.; LUO, Z.; QUIGG, A. The algal toxicity of silver engineered nanoparticles and detoxification by exopolymeric substances. Environ. Pollut., v. 157, n. 30, p. 34-41, 2009.

MICHELSON, E. S. Globalization at the nano frontier: the future of nanotechnology policy in the United States, China, and India. Technology in Society, v. 30, p. 405-410, 2008.

MIE, G. Beiträge zur Optik trüber Medien, speziell kolloidaler Metallösungen. Annalen der Physik, Vierte Folge, v. 25, p. 377-445, 1908.

MONTEIRO, D. R.; GORUP, L. F.; TAKAMIYA, A. S.; RUVOLLO-FILHO, A. C.; DE CAMARGO, E. R.; BARBOSA, D. B. The growing importance of materials that prevent microbial adhesion: antimicrobial effect of medical devices containing silver. International Journal of Antimicrobial Agents, v. 34, p. 103-110, 2009.

MOORES, A.; GOETTMANN, F. The plasmon band in noble metal nanoparticles: an introduction to theory and applications. New J. Chem., v. 30, p. 1121-1132, 2006.

MORONES, J. R.; ELECHIGUERRA, J. L.; CAMACHO, A.; HOLT, K.; KOURI, J. B.; RAMIREZ, J. T.; YACAMAN, M. J. The bactericidal effect of silver nanoparticles. Nanotechnology, v. 16, p. 2346-2353, 2005.

NARAYANAN, K. B.; SHAKTIVEL, N. Biological synthesis of metal nanoparticles by microbes. Adv. Colloid Interf. Sci., v. 156, p. 1-13, 2010.

NAVARRO, E.; PICCAPIETRA, F.; WAGNER, B.; MARCONI, F.; KAEGI, R.; ODZAK, N.Toxicity of silver nanoparticles to Chlamydomonas reinhardtii. Environ Sci Technol., v. 42, n. 89 , p. 59-64, 2008 b. 
NIOSI, J.; REID, S. E. Biotechnology and nanotechnology: science-based enabling technologies as windows of opportunity for LDCs?. World Development, v. 35, n. 3, p. 426438, 2007.

ONO, L. K.; ROLDÁN-CUENYA, B. Effect of interparticle interaction on the low temperature oxidation of $\mathrm{CO}$ over size - selected $\mathrm{Au}$ nanocatalysts supported on ultrathin $\mathrm{TiC}$ films. Catalysis Letters, v. 113, n. 3-4, p. 86-94, 2007.

OSONO, T. Endophytic and epiphytic phyllosphere fungi of Camellia japonica: seasonal and leaf age-dependent variations. Mycologia, v. 100, n. 3, p. 387-391, 2008.

OSONO, T.; FUKASAWA, Y.; TAKEDA, H. Role of diverse fungi in larch needle litter decomposition. Mycologia, v. 95, p. 820-826, 2003.

ÖZYÜREK, M.; GÜNGÖR, N.; BAKI, S.; GÜÇLÜ, K.; APAK, R. Development of a silver nanoparticle-based method for the antioxidant capacity measurement of polyphenols. Anal. Chem., v.84, p. 8052-8059, 2012.

PALOMINO, J. C.; MARTIN, A.; CAMACHO, M.; GUERRA, H.; SWINGS, J.; PORTAELS, F. Resazurin microtiter assay plate: simple and inexpensive method for detection of drug resistance in Mycobacterium tuberculosis. Antimicrob. Agents Chemother., v. 46, p. 2720-2722, 2002.

PANÁČEK, A.; KOLÁR̆, M.; VEČEŘOVÁ, R.; PRUCEK, R.; SOUKUPOVÁ, J.; KRYŠTOF, V.; HAMAL, P.; ZBOŘIL, P.; KVÍTEK, L. Antifungal activity of silver nanoparticles against Candida spp. Biomaterials, v. 3, p. 6333-6340, 2009.

PANYALA, N. R.; PEÑA-MÉNDEZ, E. M.; HAVEL, J. Silver or silver nanoparticles: a harzadous threat to the environment and human health?. Applied Biomedicine, v. 6, p. 117$129,2008$.

PARK, EUN-JUNG.; Y. I, J.; KIM, Y.; CHOI, K.; PARK, K. Silver nanoparticles induce cytotoxicity by a trojan-horse type mechanism. Toxicology in Vitro, v. 24, p. 872-878, 2010.

PEIXOTO, R.; CHAER, G. M.; CARMO, F. L.; ARAÚJO, F. V.; PAES, J. E.; VOLPON, A.; SANTIAGO, G. A.; ROSADO, A. S. Bacterial communities reflect the spatial variation in pollutant levels in Brazilian mangrove sediment. Antonie Van Leeuwenhoek, v. 99, n. 2, p. 341-54, 2011.

PEREIRA, G. H.; MULLER, P. R.; SZESZS, M. W.; LEVIN, A. S.; MELHEM, M. S. Fiveyear evaluation of bloodstream yeast infections in a tertiary hospital: the predominance of non-C. albicans Candida species. Medical Mycology, v. 48, p. 839-842, 2010.

PEREIRA, M. K. Ressonância de plasmon de superfície localizado e espalhamento raman em soluções coloidais de ouro. 2009. 107 f. Dissertação (Mestrado em Física) Universidade Fedral do Rio Grande do Sul, 2009.

PETRYAYEVA, E.; KRULL, U. J. Localized surface plasmon resonance: nanostructures, bioassays and biosensing-a review. Analytica Chimica Acta, v. 706, p. 8-24, 2011. 
PRABHUA, D.; ARULVASUA, C.; BABUA, G.; MANIKANDANB, R.; SRINIVASAN, P. Biologically synthesized green silver nanoparticles from leaf extract of Vitex negundo $L$. induce growth-inhibitory effect on human colon cancer cell line HCT15. Process Biochemistry, v. 48, n. 2 p. 317-324, 2013.

PRESCHITSCHEK, N; DOMINIC, B. Nanotechnology patenting in China and Germany - a comparison of patent landscapes by bibliographic analyses. Journal of Business Chemistry, 7, v. 1, p. 3-13, 2010.

PRIETO, G.; ZECEVIC, J.; FRIEDRICH, H.; DE JONG, K. P.; DE JONGH, P. E. Towards stable catalysts by controlling collective properties of supported metal nanoparticles. Nature Materials, p. 34-39, 2012.

PUURUNEN, K.; VASARA, P. Opportunities for utilising nanotechnology in reaching nearzero emissions in the paper industry. Journal of Cleaner Production, v. 15 p. 1287-1294, 2007.

RAEDER, U.; BRODA, P. Rapid preparation of DNA from filamentous fungi. Lett. Appl. Microbiol., v. 1, p. 17-20, 1985.

RAI, M.; YADAV, A.; GADE, A. Silver nanoparticles as a new generation of antimicrobials. Biotechnology Advances. v. 27, p. 76-83, 2009.

RANI, P. U., RAJASEKHARREDDY, P. Green synthesis of silver-protein (core-shell) nanoparticles using Piper betle L. leaf extract and its econtoxicological studies on Daphnia magna. Colloids and Surface A: Physicochemical and Engineering Aspects, v. 389, p. 188-194, 2011.

RAVINDRA, S.; MOHAN, Y. M.; REDDY, N. N.; RAJU, K. M. Fabrication of antibacterial cotton fibres loaded with silver nanoparticles via "Green Approach". Colloids Surf. A, v. 367, p. 31-40, 2010.

RENUGADEVI, K.; ASWINI, R.V. Microwave irradiation assisted synthesis of silver nanoparticle using Azadirachta indica leaf extract as a reducing agent and in vitro evaluation of its antibacterial and anticancer activity. International Journal of Nanomaterials and Biostructures, v. 2, n. 2, p. 5-10, 2012.

RIGONATO, J.; KENT, A. D.; ALVARENGA, D. O.; ANDREOTE, F. D.; BEIRIGO, R. M.; VIDAL-TORRADO, P.; FIORE, M. F. Drivers of cyanobacterial diversity and community composition in mangrove soils in south-east Brazil. Environmental Microbiology, v. 15, p. 1103-1114, 2013.

RODRIGUES, A. G.; PING L. Y.; MARCATO, P. D.; ALVES, O. L.; SILVA, M. C. P.; RUIZ, R. C.; MELO, I. S.; TASIC, L.; DE SOUZA, A. O. Biogenic antimicrobial silver nanoparticles produced by fungi. Appl. Microbiol. Biotechnol., v. 97, p. 775-782, 2013

RODRIGUEZ, R. J.; JR, J. F. W.; ARNOLD, A. E.; REDMAN, R. S. Fungal endophytes: diversity and functional roles. New Phytologist, p. 1-17, 2009.

RULKA, E. L.; LIMA, M.; NEVES, E. B. Perfil das publicações científicas sobre a infecção hospitalar na base de dados SciELO. J. Health Sci. Inst., v. 30, n. 2, p. 161-165, 2012. 
RUPARELIA, J. P.; CHATTERJEE A. K.; DUTTAGUPTA, S. P.; MUKHERJI, S. Strain specificity in antimicrobial activity of silver and copper nanoparticles. Acta Biomater., v. 4, n. 70, p. 707-716, 2008.

SAITOU, N.; NEI, M. The neighbor-joining method: a new method for reconstructing phylogenetic trees. Mol. Biol. Evol., v. 4, p. 406-425, 1987.

SALUNKHE, R. B.; PATIL, S. V.; SALUNKE, B. K.; PATIL, C. D.; SONAWANE, A. M. Studies on silver accumulation and nanoparticle synthesis by Cochliobolus lunatus. Applied Biochem. Biotechnol., v.165, p. 221-234, 2011.

SARGENT JR, J. F. The national nanotechnology initiative: overview, reauthorization, and appropriations issues: specialist in science and technology policy, Congressional Research Service, 2012.

SATHISHKUMAR, M.; SNEHA, K,; YUN, Y. S. Immobilization of silver nanoparticles synthesized using Curcuma longa tuber powder and extract on cotton cloth for bactericidal activity. Bioresource Technol., v. 101, p. 7958-7965, 2010.

SCHAEFFER-NOVELLI, Y. Manguezal: ecossistema entre a terra e o mar. São Paulo, SP: Caribbean Ecological Research, 1995. 64 p.

SEBASTIANES, F. L. S.; LACAVA, P. T.; FÁVARO, L. C. L.; RODRIGUES, M. B. C.; ARAÚJO, W. L.; AZEVEDO, J. L.; PIZZIRANI-KLEINER, A. A. Genetic transformation of Diaporthe phaseolorum, an endophytic fungus found in mangrove forests, mediated by Agrobacterium tumefaciens. Current Genetics, v. 58, p. 21-33, 2012.

SELVAKUMAR, R.; JOTHI, N. A.; JAYAVIGNESH, V.; KARTHIKAISELVI, K.; ANTONY, G. I.; SHARMILA, P. R.; KAVITHA, S.; SWAMINATHAN, K. As(V) removal using carbonized yeast cells containing silver nanoparticles. Water Research, v. 45, p. 583$592,2011$.

SHALIGRAM, N. S.; BULE, M.; BHAMBURE, R.; SINGHAL, R. S.; SINGH, S. K.; SZAKACS, G.; PANDEY. A. Biosynthesis of silver nanoparticles using aqueous extract from the compactin producing fungal strain. Process Biochem. v. 44, p. 939-943, 2009.

SHELAR, P. S.; REDDY, V. K.; SHELAR, G. S.; REDDY, V. S. Medicinal value of mangroves and its antimicrobial properties - a review. Continental J. Fisheries and Aquatic Science, v. 6. n. 1, p. 26-37, 2012.

SINTUBIN, L.; DE WINDT, W.; DICK, K.; MAST, J.; VAN DER HA, D.; VERSTRAETE, $\mathrm{W}$.; Boon, N. Lactic acid bacteria as reducing and capping agent for the fast and efficient production of silver nanoparticles. Appl. Microbiol. Biotechnol., v. 84, p. 741-749, 2009.

SILVA, M. R. O.; ALMEIDA, A. C.; ARRUDA, F. V. F.; GUSMÃO, N. Endophytic fungi from brazilian mangrove plant Laguncularia racemosa (L.) Gaertn. (Combretaceae): their antimicrobial potential. Formatex, p. 1260-1266, 2011.

SILVER, S. Bacterial silver resistance: molecular biology and uses and misuses of silver compounds. FEMS Microbiology Reviews, v. 27, p. 341-353, 2003. 
SILVERSTEIN, R.; WEBSTER, F.; KIEMLE, D. Spectrometric identification of organic compounds. 7th ed. New York: John Wiley and Sons, 2005.

SONDI, I; SALOPEK-SONDI, B. Silver nanoparticles as antimicrobial agent: a case study on E. coli as a model for Gram-negative bacteria. J. Colloid Interface Sci., v. 275, p. 177-182, 2004.

SULAIMAN, G. M.; MOHAMMED, W. H.; MARZOOG, T. R.; AL-AMIERY, A. A. A.; KADHUM, A. A. H.; MOHAMAD, A. B. Green synthesis, antimicrobial and cytotoxic effects of silver nanoparticles using Eucalyptus chapmaniana leaves extract. Asian Pac. J. Trop. Biomed., v. 3, n. 1, p. 58-63, 2013.

SUN, X.; LUO, Y. Preparation and size control of silver nanoparticles by a thermal method. Materials Letters, v. 59, p. 3847-3850, 2005.

TAMURA, K.; DUDLEY, J.; NEI, M.; KUMAR, S. MEGA4: Molecular Evolutionary Genetics Analysis (MEGA) software version 4.0. Mol. Biol. Evol., v. 24, p.1596-1599, 2007.

TEPASKE, M. R.; GLOER, J. B.; WICKLOW, D. T.; DOWD, P. Three new aflavinines from the sclerotia of Aspergillus tubingensis. Tetrahedron, v. 45, p. 4961-4968, 1989a.

THOMPSON, J. D.; HIGGINS, D. G.; GIBSON, T.J. CLUSTAL W: improving the sensitivity of progressive multiple sequence alignment through sequence weighting, positionspecific gap penalties and weight matrix choice. Nucleic Acids Res., v. 22, p. 4673-4680, 1994.

TOMA, H. E; BONIFÁCIO, L. S.; ANAISSI, F. J. Da cor à cor inexistente: uma reflexão sobre espectros eletrônicos e efeitos cromáticos. Quim. Nova, v. 28, n. 5, p. 897-900, 2005.

TURKEVITCH, J.; STEVENSON, P. C.; HILIER J. A study of the nucleation and growth processes in the synthesis of colloidal gold. Discuss. Faraday Soc., v. 11, p. 55, 1951.

VALDEN, M.; LAI, X.; GOODMAN, D. W. Onset of catalytic activity of gold clusters on titania with the appearance of nonmetallic properties. Science, v. 281, p. 1647-1650, 1998.

VIEIRA, B. P.; DIAS, D.; NAKAMURA, E. M.; ARAI, T. I.; HANAZAKI, N. Is there temporal variation on solid waste stranding in mangroves? A case study in ratones mangrove, Florianopolis, Brazil. Biotemas, v. 26, n. 1, p. 79-86, 2013.

VIGNESHWARAN, N.; ASHTAPUTRE, N. M.; VARADARAJAN, P. V.; NACHANE, R. P.; BALASUBRAMANYA, R. H. Biological synthesis of silver nanoparticles using the fungus Aspergillus flavus. Colloids Surf. B, v. 61, p. 1314-1318, 2007.

VIGNESHWARAN, N.; KATHE, A. A.; VARADARAJAN, P.V.; NACHANE, R. P.; BALASUBRAMANYA, R. H. Biomimetics of silver nanoparticles by white rot fungus, Phaenerochaete chrysosporium. Colloids Surf. B., v. 53, p. 55-59, 2006.

WARREN, N. G.; SHADOMY, H. J. Yeasts of medical importance. In: BALOWS, A.; HAUSLER JR. W. J.; HERRMANN, K. L.; ISENBERG, H. D.; SHADOMY, H. J. (Ed.). Manual of clinical microbiology. 5th ed. Washington: ASM, 1991. 
WHITE, R. J.; COOPER, R. Silver sulphadiazine: a review of the evidence. Wounds U.K., p. 52-61, 2005.

WILEY, B. J.; IM, S. H.; LI, ZHI-YUAN.; MCLELLAN, J.; SIEKKINEN, A.; XIA, Y. Maneuvering the surface plasmon resonance of silver nanostructures through shape-controlled synthesis. J. Phys. Chem. B, v. 110, p. 15666-15675, 2006.

WORLD HEALTH ORGANIZATION. Prevention of hospital-acquired infections A practical guide 2nd 2002. edition. Disponível em: <http://www,who,int/csr/resources/publications/whocdscsreph200212,pdf>. Acesso em: 10 jan. 2012.

YANG, XIU-HUA; LING, J.; PENG, J.; CAO, QIU-E.; WANG, L.; DING, ZHONG-TAO; XIONG, J. Catalytic formation of silver nanoparticles by bovine serum albumin protected silver nanoclusters and its application for colorimetric detection of ascorbic acid. Spectrochimica Acta Part A: Molecular and Biomolecular Spectroscopy, v. 106, p. 224$230,2012$.

YEO, M. K.; YOON, J. W. Comparison of the effects of nano-silver antibacterial coatings and silver ions on zebrafish embryogenesis. Mol. Cell. Toxicol., v. 5, p. 23-31, 2009.

YING, G.; LU, H.; PORTER, A. L. The research profiling method applied to nano-enhanced, thin film solar cells. R\&D Management, v. 40, n. 2, p. 195-208, 2010.

YOON, K-Y.; HOON, B. J.; PARK, J-H.; HWANG, J. Susceptibility constants of Escherichia coli and Bacillus subtilis to silver and copper nanoparticles. Sci. Total Environ., v. 373, n. 57, p. 2-5, 2007.

ZHAN, J. X.; GUNAHERATH, G. M. K. B.; WIJERATNE, E. M. K.; GUNATILAKA, A. A. L. Asperpyrone D and other metabolites of the plant-associated fungal strain Aspergillus tubingensis. Phytochemistry, v. 68, p. 368-372, 2007.

ZHANG, M.; ZHANG, K.; DE GUSSEME, B.; VERSTRAETE, W. Biogenic silver nanoparticles (bio-Ag0) decrease biofouling of bio-Ag0/PES nanocomposite membranes. Water Research, v. 46, p. 2077-2087, 2012.

ZHANG, X.; YAN, S.; TYAGI, R. D.; SURAMPALLI, R. Y. Synthesis of nanoparticles by microorganisms and their application in enhancing microbiological reaction rates. Chemosphere, v. 82, p. 489-494, 2011. 


\title{
Biogenic antimicrobial silver nanoparticles produced by fungi
}

\author{
Alexandre G. Rodrigues \& Liu Yu Ping \& \\ Priscyla D. Marcato \& Oswaldo L. Alves \& \\ Maria C. P. Silva \& Rita C. Ruiz \& Itamar S. Melo \& \\ Ljubica Tasic \& Ana O. De Souza
}

Received: 17 February 2012 /Revised: 24 May 2012 / Accepted: 31 May 2012 /Published online: 16 June 2012

\# Springer-Verlag 2012

\begin{abstract}
Aspergillus tubingensis and Bionectria ochroleuca showed excellent extracellular ability to synthesize silver nanoparticles $(\mathrm{Ag} \mathrm{NP})$, spherical in shape and $35 \pm$ $10 \mathrm{~nm}$ in size. Ag NP were characterized by transmission electron microscopy, X-ray diffraction analysis, and photon correlation spectroscopy for particle size and zeta potential. Proteins present in the fungal filtrate and in Ag NP dispersion were analyzed by electrophoresis (sodium dodecyl sulfate polyacrylamide gel electrophoresis). Ag NP showed pronounced antifungal activity against Candida sp, frequently occurring in hospital infections, with minimal inhibitory concentration in the range of $0.11-1.75 \mu \mathrm{g} / \mathrm{mL}$. Regarding antibacterial activity, nanoparticles produced by A. tubingensis were more effective compared to the other fungus, inhibiting $98.0 \%$ of Pseudomonas. aeruginosa growth at $0.28 \mu \mathrm{g} / \mathrm{mL}$. A. tubingensis synthesized Ag NP with surprisingly high and positive surface potential,
\end{abstract}

A. G. Rodrigues ${ }^{\prime}$ L. Y. Ping ${ }^{\prime}$ A. O. De Souza $(*)$

Laboratório de Bioquímica e Biofísica, Instituto Butantan,

Av. Vital Brasil, 1500,

05503-900, São Paulo, São Paulo, Brazil

e-mail: olivia@butantan.gov.br

P. D. Marcato ${ }^{\text {O. L. L. Alves }}{ }_{\text {L. Tasic }}$

IQ, Universidade Estadual de Campinas,

São Paulo, Brazil

M. C. P. Silva

ICB, Universidade de São Paulo,

São Paulo, Brazil

R. C. Ruiz

Laboratório de Bacteriologia, Instituto Butantan,

São Paulo, Brazil

I. S. Melo

Embrapa Meio Ambiente,

São Paulo, Brazil differing greatly from all known fungi. These data open the possibility of obtaining biogenic Ag NP with positive surface potential and new applications.

Keywords Silver nanoparticles · Antimicrobial activity · Aspergillus tubingensis $\cdot$ Bionectria ochroleuca $\cdot$ Mangrove

Introduction

Silver nanoparticles (Ag NP) have many important applications including single electron transistors, fuel cells, fluorescent labeling, and DNA/RNA detection via specific probes, as well as potential use in biomedical diagnostic devices, biosensors, nanocomputers, agriculture, and medicine (Zhang et al. 2011). In medicine, scientists have made many efforts to develop antimicrobial agents or formulations that could be used in clinical treatments against pathogenic fungi or bacteria. Resistant and multiresistant pathogens are frequently present in hospital areas, complicating the treatment and cure of infections caused by such microorganisms. In this respect, $\mathrm{Ag}$ NP show very interesting antimicrobial properties (Gade et al. 2008) and have been applied in a wide range of products such as those for preventing hospital infection (Durán et al. 2010).

Ag NP can be produced by chemical or biological methods. Li et al. $(2010,2011)$ demonstrated the antibacterial effect of Ag NP produced by chemical methods against Staphylococcus aureus and Escherichia coli. A significant antibacterial effect of Ag NP produced by the Fusarium oxysporum 07 SD strain and incorporated into cotton fabric was observed against $\mathrm{S}$. aureus (Durán et al. 2007). Also, S. aureus and E. coli were susceptible to the action of $\mathrm{Ag} \mathrm{NP}$ produced by Aspergillus niger isolated from soil (Gade et al. 2008). 
Broad antimicrobial activity of the Ag NP produced by the fungus Amylomyces rouxii strain KSU-09 was shown against both Gram-negative and Gram-positive bacteria, as well as human and plant pathogenic fungi, including Shigella dysenteriae type I, S. aureus, Pseudomonas aeruginosa, Bacillus subtilis, Candida albicans, and F. oxysporum (Musarrat et al. 2010).

Antimicrobial activity has also been observed with Ag NP synthesized by strains of E. coli and A. niger isolated from coastal mangrove sediment of southeast India (Kathiresan et al. 2010). The biosynthesis of Ag NP by Penicillium fellutanum, a fungus isolated from coastal mangrove sediment in India, was also reported (Kathiresan et al. 2009). These studies demonstrated the potential application of fungi from mangrove in Ag NP synthesis.

The mangrove ecosystem is rich in biochemical processes. Brazil's mangrove areas are vast and cover approximately $10,000 \mathrm{~km}^{2}$; they are rich in flora, fauna, and microorganisms that are scarcely studied. However, to date, the application of fungi from a Brazilian mangrove in Ag NP synthesis has not been described or reported in the literature.

This study reports on the synthesis of Ag NP using two fungal species isolated from the mangrove forest along Cananeia Coast (Sao Paulo coastal area, Brazil). Fungi were taxonomically identified, and the Ag NP obtained were thoroughly characterized and also investigated for their applicability as antimicrobial agents against clinical pathogens. This is the first report of the extracellular synthesis and antimicrobial properties of Ag NP produced by fungi isolated from a Brazilian mangrove.

Material and methods

Isolation of the fungi

Plants belonging to the mangrove species Rhizophora mangle and Laguncularia racemosa were collected in a preserved mangrove forest located in Cananeia Coast in Sao Paulo State, Brazil. Samples were kept in an ice box until their arrival at the Environmental Microbiology Laboratory of Embrapa Environmental in the city of Jaguariuna, Sao Paulo State.

The epiphytic fungus L-2-2 was isolated from L. racemosa without previous sterilization of the leaves. The endophytic fungi coded as MGE-201 was isolated from R. mangle according to the method described by Araújo et al. (2001). For both epiphytic and endophytic fungi, leaf fragments of $5 \mathrm{~mm}$ were placed on potato dextrose agar (PDA, Himedia M096) containing $100 \mu \mathrm{g} / \mathrm{mL}$ tetracycline and then incubated for 7 days at $28^{\circ} \mathrm{C}$. Fungal colonies growing from the tips of the fragments were then transferred to PDA, isolated, and preserved in PDA medium, by the Castellani method, and also kept at $-70^{\circ} \mathrm{C}$.
Molecular characterization of the fungi

Genomic DNA extraction

The fungi L-2-2 and MGE-201 were cultured in potato dextrose broth (PDB, Himedia M403) at $28{ }^{\circ} \mathrm{C}$ for a week, and their genomic DNA was extracted based on protocols described by Raeder and Broda (1985) and González-Mendoza et al. (2010). Briefly, $10 \mathrm{mg}$ of each freeze-dried mycelium was vigorously stirred with $200 \mu \mathrm{L}$ of extraction buffer (3\% dodecyl sodium sulfate (SDS), $0.5 \mathrm{mM}$ EDTA, $1 \mathrm{M} \mathrm{NaCl}$, and $0.1 \mathrm{mM}$ Tris- $\mathrm{HCl}, \mathrm{pH} 8.0$ ) for $15 \mathrm{~s}$. The mixture was homogenized with $200 \mu \mathrm{L}$ of chloroform/phenol/isoamyl alcohol $(25: 24: 1, \mathrm{v} / \mathrm{v} / \mathrm{v})$ and incubated at $65^{\circ} \mathrm{C}$ for $5 \mathrm{~min}$. After cooling to room temperature, the mixture was centrifuged at $10,000 \times \mathrm{g}$, at $4{ }^{\circ} \mathrm{C}$ for $5 \mathrm{~min}$. The supernatant was transferred to a new microtube and vigorously stirred with an equal volume of absolute ethanol. Following incubation at $-20{ }^{\circ} \mathrm{C}$ for $20 \mathrm{~min}$, the mixture was centrifuged at $10,000 \times \mathrm{g}$ for $10 \mathrm{~min}$ and the supernatant discarded. The pellet was washed twice with $75 \%$ ethanol and centrifuged at $10,000 \times \mathrm{g}$, at $4{ }^{\circ} \mathrm{C}$ for $5 \mathrm{~min}$. The DNA obtained was dissolved in $30 \mu \mathrm{L}$ of sterile deionized water and kept at $-20{ }^{\circ} \mathrm{C}$. A sample $(10 \mu \mathrm{L})$ was analyzed by electrophoresis (Bio-Rad) using a $1 \%$ agarose gel (w/v). DNA was quantified in a microplate spectrophotometer (Molecular Device), and purity was estimated according to the $\mathrm{A}_{260} / \mathrm{A}_{280}$ ratio.

\section{Amplification of the ITS regions}

For MGE-201 fungus, the ITS region was amplified using forward ITS1 primer, (5' CCCGCCGCGCGCGGCGGGCG GGGC $3^{\prime}$ ) and reverse ITS4 primer (5' TCCTCCGCTTATTGATATGC $3^{\prime}$ ). For L-2-2 fungus, the primers were ITS1F (5' CTTGGTGATTTAGAGGAAGTAA 3') and the same ITS4 reverse primer.

For PCR analysis, a solution of $25 \mu \mathrm{L}$ was prepared with $20 \mathrm{ng}$ of extracted DNA from the fungi (L-2-2 and MGE201), $1.5 \mathrm{mM} \mathrm{MgCl} 2,0.2 \mathrm{mM}$ dNTPs, $1.0 \times$ reaction buffer (Tris-HCl, pH 9.0, PCR enhancers $\left(\mathrm{NH}_{4}\right)_{2} \mathrm{SO}_{4}, 20 \mathrm{mM}$ $\left.\mathrm{MgCl}_{2}\right), 0.5 \mu \mathrm{M}$ of each primer, and $1 \mathrm{U}$ Taq polymerase (Prime Taq ${ }^{\mathrm{TM}}$ DNA polymerase Genet Bio). PCR amplification was carried out using 30 cycles at the following conditions: $30 \mathrm{~s}$ at $94{ }^{\circ} \mathrm{C}$ for denaturation, $30 \mathrm{~s}$ for annealing (at $42.6{ }^{\circ} \mathrm{C}$ for L-2-2 and at 55.1 ${ }^{\circ} \mathrm{C}$ for MGE-201), and $60 \mathrm{~s}$ at $72{ }^{\circ} \mathrm{C}$ for extension. An initial denaturation step $\left(95^{\circ} \mathrm{C}\right.$ for $60 \mathrm{~s}$ ) was used to ensure complete denaturation of the template DNA. The amplifications were performed in a Mastercycler gradient instrument (Eppendorf).

PCR products were first analyzed by electrophoresis with $1 \%$ (w/v) agarose gel and ethidium bromide staining. PCR products were purified using GeneJET ${ }^{\mathrm{TM}}$ Gel Extraction kit (Fermentas) and then sequenced. The sequencing reactions were 
performed using an ABI 3730 DNA Analyzer with the primers

ITS1, ITS1F, or ITS4 and the BigDye ${ }^{\circledR}$ Terminator v3.1 Cycle Sequencing kit (PE Applied Biosystems, Carlsbad, CA, USA).

Sequence analyses

The partial sequences of $28 \mathrm{~S}$ rDNA were compared to those deposited in GenBank using the Blast tool at the National Center for Biotechnology Information website (http://www.ncbi.nlm.nih.gov) and CBS (http:// www.cbs.knaw.nl/). The sequences were aligned using the CLUSTAL X program (Thompson et al. 1994) and analyzed with MEGA software version 4.0 (Tamura et al. 2007). The evolutionary distance matrices were calculated using the Kimura model (1980), and construction of the phylogenetic trees from evolutionary distances was carried out by the neighbor-joining algorithm (Saitou and Nei 1987), with bootstrap values calculated from 1,000 replicate runs.

\section{Nanoparticle synthesis}

The epiphytic (L-2-2) and the endophytic (MGE-201) fungi were cultivated in PDA at $28{ }^{\circ} \mathrm{C}$ for a week. Afterwards, the fungal colonies were transferred to tubes containing $5 \mathrm{~mL}$ of saline. Each suspension obtained was added to $150 \mathrm{~mL}$ of PDB in a 1-L Erlenmeyer flask and incubated on an orbital shaker (Marconi MA420, Brazil) at $25^{\circ} \mathrm{C}$ and $150 \mathrm{rpm}$ for $72 \mathrm{~h}$. After this period, the biomass was filtered using a polypropylene membrane and washed with sterile water to remove any residual medium. The biomass was incubated in sterile distilled water $(0.1 \mathrm{~g} / \mathrm{mL})$ at $25{ }^{\circ} \mathrm{C}$ and $150 \mathrm{rpm}$ for $72 \mathrm{~h}$. After incubation, the biomass was removed by filtration through a polypropylene membrane, and the fungal filtrate (FF) was passed through a $0.22-\mu \mathrm{m}$ polyethersulfone membrane in a Millipore system (Stericup ${ }^{\circledR}$ filter units) to remove any residual cells.

For Ag NP synthe sis, $1 \mathrm{~mL}$ of $\mathrm{AgNO}_{3}$ solution $(100 \mathrm{mM})$, previously filtered through a 0.22 $\mu \mathrm{M}$ mem- brane (Millipore), was added to $99 \mathrm{~mL}$ of the specific FF to a final concentration of $1 \mathrm{mM}$. The flasks were kept at $25{ }^{\circ} \mathrm{C}$ and protected from light for $96 \mathrm{~h}$. Aliquots of $1 \mathrm{~mL}$ were periodically withdrawn every hour and absorbance was measured in a UV-VIS spectrophotometer (Agilent 8453). Control (FF without any silver ions) was also pre- pared using the same conditions.

\section{Analysis of silver nanoparticles}

Transmission electron microscopy

The nanoparticles were characterized by transmission electron microscopy (TEM)-elemental spectroscopy imaging
(ESI). Bright-field images and the elemental distribution of Ag NP were obtained using a Carl Zeiss CEM-902 transmission electron microscope (80 keV), equipped with a Castaing-Henry-Ottensmeyer energy filter spectrometer within the column. For analysis of the $\mathrm{Ag} \mathrm{NP}$, one drop of the diluted dispersion of particles was deposited on carboncoated parlodium films on 300 mesh copper grids (Ted Pella). Images were recorded by a Proscan high-speed slow-scan CCD camera and processed in the Analysis 3.0 system. Elemental images were obtained for the relevant elements found in this sample, using monochromatic electrons corresponding to the sulfur L2,3-edge. The energy selecting slit was set at $367 \pm 6 \mathrm{keV}$ for $\mathrm{Ag}$ and $165 \pm 6 \mathrm{eV}$ for $\mathrm{S}$.

X-ray diffraction analysis

X-ray diffraction (XRD) analysis was recorded (model $\mathrm{XD} 3 \mathrm{~A}$ Shimadzu) with nickel-filtered $\mathrm{Cu}-\mathrm{K} \alpha$ radiation $(40 \mathrm{kV}, 30 \mathrm{~mA})$ at an angle of $2 \theta$ from $5^{\circ}$ to $50^{\circ}$. The scan speed was $0.02^{\circ} / \mathrm{min}$ and the time constant was $2 \mathrm{~s}$.

Particle size and zeta potentials

The average particle size and size distribution were measured by photon correlation spectroscopy (PCS) (Nano ZS Zetasizer, Malvern Instruments Corp, UK) at $25{ }^{\circ} \mathrm{C}$ in polystyrene cuvettes with a path length of $10 \mathrm{~mm}$. The zeta potential was measured in capillary cells with a path length of $10 \mathrm{~mm}$, using the Nano ZS Zetasizer. Measurements were performed in $0.1 \mathrm{mM} \mathrm{NaCl}$.

\section{SDS-PAGE analysis}

After Ag NP synthesis ( $24 \mathrm{~h}$ ), the proteins were analyzed by SDS-PAGE electrophoresis. Nanoparticle suspensions of $50 \mathrm{~mL}$ (L-2-2 and MGE-201) were precipitated by adding solid ammonium sulfate to saturation $(80 \% \mathrm{w} / \mathrm{v})$. Proteins were concentrated using Amicon Ultra-15 centrifugal filter units of $10 \mathrm{kDa}$ (Millipore). For desalting, the concentrated proteins were washed with sodium phosphate buffer (0.05 M, pH 8.0) at least three times. Afterwards, the samples were dialyzed overnight against the same sodium phosphate buffer $(0.05 \mathrm{M}, \mathrm{pH} 8.0)$. The same procedure was performed starting with $50 \mathrm{~mL}$ of each FF. Samples were analyzed by SDS-PAGE $(7.5 \%)$ electrophoresis and gels were stained with Coomassie Brilliant Blue to evaluate purity and to determine the molecular weight of the proteins present in the samples. The protein standards with molecular weights ranging from 10 to $260 \mathrm{kDa}$ (Fermentas \#SM1841) were used. Protein concentration was determined using the Coomassie Protein Assay reagent (Pierce \# 1856209) (Bradford 1976). 
Antimicrobial activity

\section{Microorganisms}

The pathogens used in this study were obtained from the American Type Culture Collection (ATCC) and clinically isolated strains from the Microbiology Department at Sao Paulo Federal University (Sao Paulo, Brazil) or from Adolfo Lutz Institute (Sao Paulo, Brazil). Clinical strains were deposited at Oswaldo Cruz Institute (IOC) Collection and coded with their respective IOC number. The microorganisms were the following: E. coli ATCC 25922, P. aeruginosa ATCC 27853, Micrococcus luteus ATCC 10240, S. aureus ATCC 25923, C. albicans ATCC 36802/IOC 3704 , C. albicans IOC 4525, C. albicans IOC 4558, C. krusei IOC 4559, C. glabrata IOC 4565, C. parapsilosis IOC 4564, Candida tropicalis IOC 4560, and C. guilliermondii IOC 4557. The isolates were identified by standard methods (Warren and Shadomy 1991) and stored at $-80{ }^{\circ} \mathrm{C}$.

Prior to testing, each fungal isolate was subcultured at least twice on PDA to ensure optimal growth characteristics, following the recommendations of the Clinical and Laboratory Standards Institute (CLSI 2002). Fungal suspensions were prepared in RPMI 1640 (Himedia) culture media at concentrations of $0.5-2.5 \times 10^{3} \mathrm{CFU} / \mathrm{mL}$, according to standard curves previously obtained.

\section{Antibacterial activity}

The antibacterial activity of Ag NP was monitored by liquid growth inhibition assay performed in microtiter plates as described elsewhere (Bulet et al. 1993). Briefly, $10 \mu \mathrm{L}$ of $\mathrm{Ag} \mathrm{NP}$ at different concentrations from 0.14 to $2.18 \mu \mathrm{g} / \mathrm{mL}(1.25$ to $20 \mu \mathrm{M})$ was added to $90 \mu \mathrm{L}$ of a suspension of a mid-logarithmic phase culture of bacteria at $1 \times 10^{5} \mathrm{CFU} / \mathrm{mL}$ in poor-broth nutrient medium (1 $\%$ Bacto-tryptone and $0.5 \%(w / v) ~ N a C l)$. Cultures were carried out in triplicate and microbial growth was assessed after incubation $\left(18 \mathrm{~h}, 150 \mathrm{rpm}, 30^{\circ} \mathrm{C}\right)$. Gentamicin was used at 8 and $16 \mu \mathrm{g} / \mathrm{mL}(17.0-34.0 \mu \mathrm{M})$ as the positive control and untreated bacteria were used as the negative control. Antibac- terial activity was expressed by percentage of growth inhibi- tion in comparison to the control (untreated bacteria).

\section{Antifungal activity - minimal inhibitory concentration}

The antifungal activity of Ag NP was evaluated by the microdilution assay as previously described (Palomino et al. 2002) at concentrations ranging from 0.9 to $110 \mu \mathrm{g} / \mathrm{mL}$ (0.008-1 mM). Amphotericin B (AMB) was used as the positive control at concentrations below $15 \mu \mathrm{g} / \mathrm{mL}(16 \mu \mathrm{M})$ and the visual minimal inhibitory concentration $\left(\mathrm{MIC}_{90}\right)$ was defined as the lowest concentration that prevents the change in color from blue to pink due to the inhibition of at least $90 \%$ of the microorganism's growth. Nanoparticles and AMB were diluted in RPMI 1640 medium, and the bioassays were performed in three independent experiments.

Results

Taxonomic identification of the fungi L-2-2 and MGE-201

The filamentous fungus, coded as L-2-2, was identified as Bionectria ochroleuca (GU5662523.1) with $98 \%$ similarity, and the phylogenetic tree showed that L-2-2 formed a group with this fungal species, supported by a bootstrap value of $95 \%$. The fungus, coded as MGE-201, showed $100 \%$ sequence similarity with different species of the genera Aspergillus, including Aspergillus foetidus (AY585551), A. tubingensis (AY585546), Aspergillus vadensis (AY585549), and A. niger (AY585553). Based on the phylogenetic tree analysis, MGE-201 formed a group with the species A. foetidus, A. tubingensis, and A. vadensis, supported by a bootstrap value of $70 \%$. Additional sequencing of the tubulin gene confirmed the identification of MGE-201 as A. tubingensis (AY876924). B. ochroleuca (L-2-2) and A. tubingensis (MGE-201) strains were deposited at the "Embrapa Recursos Genéticos e Biotecnologia (CENARGEN)" in the "Collection of Microorganisms for Biocontrol of Plant Pathogens and Weeds" (http://mwpin004.cenargen.embrapa.br/jrgnweb/ jmcohtml/jmcoconsulta-externa.jsp?idcol011) under the numbers CEN1065 and CEN1066, respectively.

\section{Characterization of silver nanoparticles}

The two FF (L-2-2 and MGE-201) treated with $\mathrm{AgNO}_{3}$ showed a change in appearance from light yellow and completely clear in the first minutes to dark-brown after the first minutes of the reaction and very turbid at $24 \mathrm{~h}$. The color changes were monitored visually and using a UV-Visible spectrophotometer demonstrating a plasmon band at $440 \mathrm{~nm}$ which is the characteristic band of metal nanoparticles. Nanoparticles were rapidly synthesized in the first $6 \mathrm{~h}$ as observed from the absorbance increase at $440 \mathrm{~nm}$, which at $96 \mathrm{~h}$ reached 0.718 and 1.428 for Ag NP of MGE-201 and L-2-2, respectively (Fig. 1).

The spherical and homogenous Ag NP synthesized by the two fungi (L-2-2 and MGE-201) were obtained with sizes of around $35 \pm 10 \mathrm{~nm}(\mathrm{TEM})$ and an XRD pattern indicating the crystalline structure of Ag NP. ESI analysis showed the presence of $\mathrm{S}$ and $\mathrm{N}$ around the $\mathrm{Ag} \mathrm{NP}$ produced by MGE-201 as shown in Fig. 2 indicating that particles are stabilized by proteins from the fungus MGE-201. The same result was observed for particles produced by L-2-2 fungus (data not shown). 


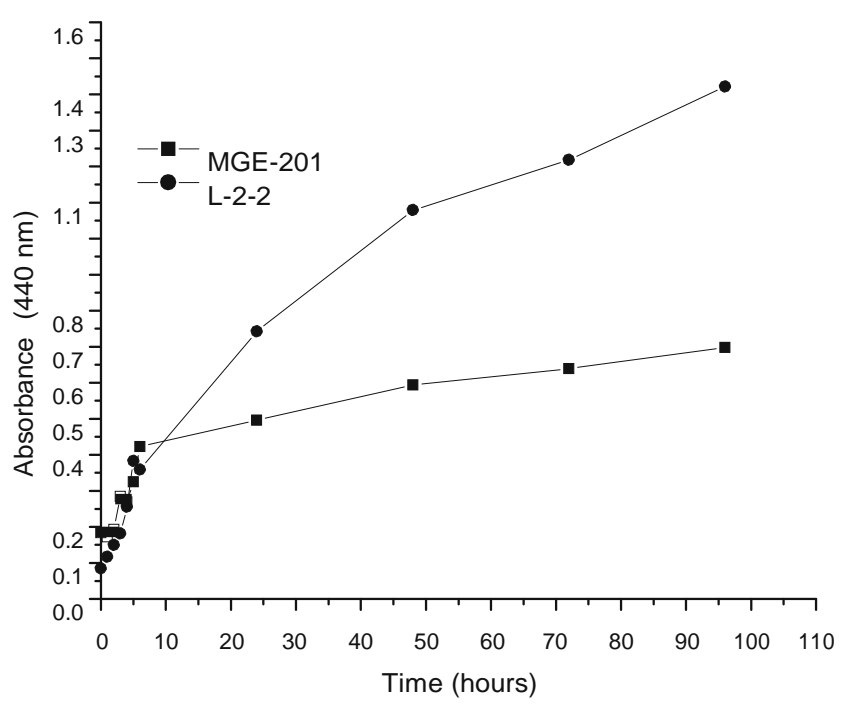

Fig. 1 Absorption spectra for silver nanoparticles synthesis at $440 \mathrm{~nm}$ (plasmon resonance) with time of reaction in an aqueous solution upon addition of $1 \mathrm{mM} \mathrm{AgNO}_{3}$ to the fungal filtrates of the fungi L2-2 (circle) and MGE-201 (square)

The results of PCS analysis showed that nanoparticleassociated proteins had sizes of 136 and $313 \mathrm{~nm}$ for L-2-2 (B. ochroleuca) and MGE-201 (A. tubingensis), respective1y. The polydispersity index was 0.137 (L-2-2) and 0.337 (MGE-201), and zeta potential -8.5 (L-2-2) and +7.8 (MGE-201). Ag NP sizes measured by PCS were greater compared to that measured by TEM due to protein capping. The Ag NP produced by the fungus MGE-201 showed particles with positive surface charge.

\section{Characterization of proteins}

Protein concentration was in the same range both in the Ag NP and in FF of the two fungi. For FF and Ag NP of MGE-201, the concentration was around $0.89 \mathrm{mg} / \mathrm{mL}$, and for L-2-2, it was 0.76 and $0.74 \mathrm{mg} / \mathrm{mL}$ for Ag NP and FF, respectively.

The results of the electrophoretic runs showed the presence of various protein bands. For MGE-201, proteins of 75, 122, 191, and $328 \mathrm{kDa}$ were observed in both FF and covering $\mathrm{Ag}$ NP (Fig. 3). For FF of L-2-2, three visible bands were detected at 70,100 , and $174 \mathrm{kDa}$, while for Ag NP there were four bands of 25, 30, 44, and $49 \mathrm{kDa}$ (data not shown).

\section{Antimicrobial activity}

The two fungi were able to synthesize Ag NP with antifungal activity against six species of Candida sp that are common causes of hospital infections, with $\mathrm{MIC}_{90}$ in the range of 0.11$1.75 \mu \mathrm{g} / \mathrm{mL}$ ( 1 to $16 \mu \mathrm{M}$ ). Clinical species of C. albicans (IOC 4525) and C. krusei (IOC 4559) were the most sensitive with growth inhibited by 0.11 and $0.22 \mu \mathrm{g} / \mathrm{mL} \mathrm{Ag} \mathrm{NP} \mathrm{syn-}$ thesized by L-22 and MGE-201, respectively.
Fig. 2 a Bright-field image of the silver nanoparticles produced by fungi MGE-201; b ESI map for Ag atoms; c ESI map for S atoms; and d ESI map for $\mathrm{N}$ atoms
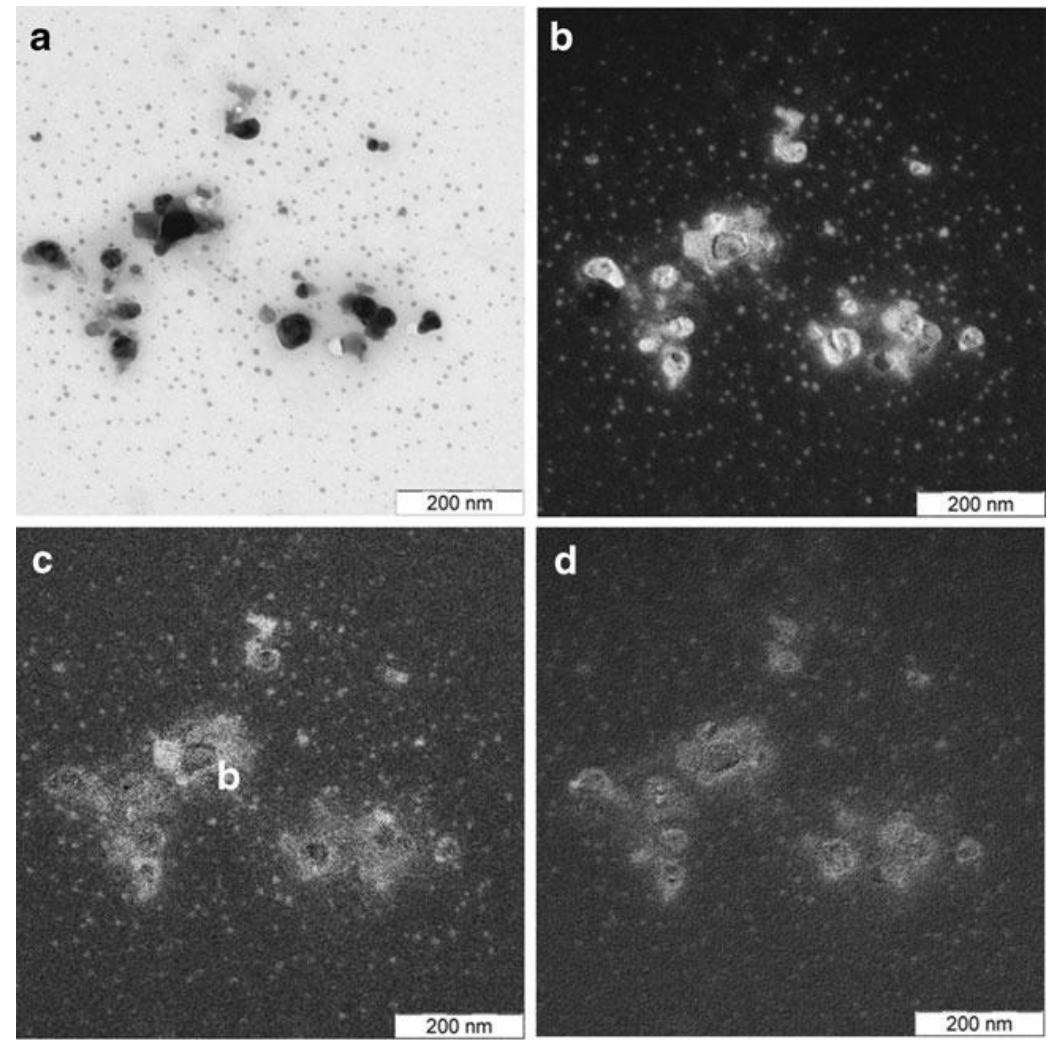


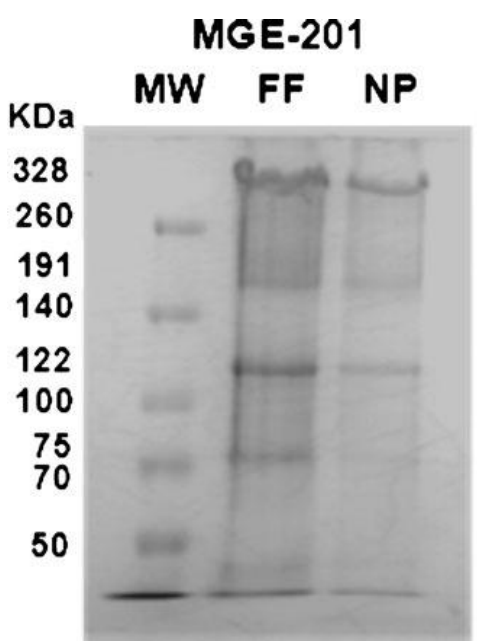

Fig. 3 SDS-PAGE of fungal filtrates (FF) and silver nanoparticles (NP) obtained with MGE-201. SDS-PAGE was carried out using

$7.5 \%$ polyacrylamide gels containing $0.1 \%$ SDS and stained with $0.1 \%$ Coomassie blue R-250 after electrophoresis. Lanes: MW molecular weight marker, FF proteins present in the fungal filtrate, and NP proteins covering the silver nanoparticles

For C. glabrata (IOC 4565), C. guillermondii (IOC 4557), and C. tropicalis (IOC 4560), Ag NP of MGE-201 showed MICs of $0.44 \mu \mathrm{g} / \mathrm{mL}$ and close to that of the antifungal drug amphotericin B (MIC $\leq 0.05-0.12 \mu \mathrm{g} / \mathrm{mL})$. The same MIC value was observed for Ag NP of L-2-2 against C. parapsilosis (IOC 4560). C. albicans (ATCC 36802) was the most resistant strain, which was inhibited with MICs of 1.75 and $27.30 \mu \mathrm{g} / \mathrm{mL}$ for Ag NP of L-2-2 and MGE-201, respectively.

As can be observed in Fig. 4, weak or no pathogen inhibition was seen with Ag NP concentrations of 0.14, 0.28 , and $0.54 \mu \mathrm{g} / \mathrm{mL}$, except for the Ag NP produced by L-2-2 fungus at $0.54 \mu \mathrm{g} / \mathrm{mL}$ against $\mathrm{S}$. aureus and P. aeruginosa and Ag NP synthesized by MGE-201 at 0.28 and $0.54 \mu \mathrm{g} / \mathrm{mL}$ on the same pathogens. At $0.71 \mu \mathrm{g} / \mathrm{mL}, \mathrm{Ag} \mathrm{NP}$ MGE-201 inhibited 99 and $98 \%$ of P. aeruginosa and S. aureus growth, respectively. The nanoparticles from L-2-2 and MGE-201 inhibited the growth of M. luteus only at concentrations above $0.71 \mu \mathrm{g} / \mathrm{mL}(6.5 \mu \mathrm{M})$ by 20.0 and $80.0 \%$, respectively. At $1.10 \mu \mathrm{g} / \mathrm{mL}(10 \mu \mathrm{M})$, the growth of almost all bacteria was inhibited by $100 \%$ mainly for MGE201 nanoparticles. Except for M. luteus at $2.20 \mu \mathrm{g} / \mathrm{mL}$, all bacteria showed growth inhibition of about $100 \%$.

\section{Discussion}

Nanoparticles were rapidly synthesized by fungi L-2-2 (B. ochroleuca) and MGE-201 (A. tubingensis) in the first $6 \mathrm{~h}$ of the reaction. Similar behaviors were noted in experiments reported by Kathiresan et al. (2010), in which Ag NP were synthesized using P. fellutanum, a fungus isolated from the mangrove root-soil in India. The results showed that the fungus L-2-2 was more efficient in reducing silver ions to Ag NP in comparison to the fungus MGE-201.

The presence of $\mathrm{S}$ and $\mathrm{N}$ around the $\mathrm{Ag} \mathrm{NP}$ as shown in Fig. 2 indicated the presence of proteins from the fungi L-22 and MGE-201 around the nanoparticles as demonstrated in previous reports for biogenic Ag NP (Durán et al. 2005, 2007; Kathiresan et al. 2010). This protein capping is very important in the stabilization of Ag NP, and in this study, in both fungal oxido-reduction processes, the nanoparticles were stable up to 90 days as measured by PCS analysis (data not shown).

It is notable that the Ag NP sizes measured by PCS were greater compared to that measured by TEM. This size difference probably occurred because hydrodynamic diameters are measured in PCS. This difference was due to the proteins surrounding the nanoparticles, which caused the formation of highly hydrated protein layers, and consequently, larger hydrodynamic diameters were obtained using this type of analysis. Furthermore, PCS results confirmed the presence of proteins around the Ag NP produced.

The zeta potentials, measured by PCS, showed that the fungus A. tubingensis (MGE-201) produced Ag NP with positive surface charge, unlike fungus B. ochroleuca (L-22) and all other previously studied fungi, which produced particles with a negative charge. Since other fungi, such as F. oxyporum and A. niger, exclusively produce Ag NP with negative surfaces (data not shown), this result was at least surprising. This is the first report of any known fungus producing Ag NP with a positive zeta potential. This characteristic can influence the antimicrobial activity of Ag NP since all bacterial cells are negatively charged at neutral $\mathrm{pH}$ (Li and Logan 2004), and an attractive electrostatic force is expected to be involved. It is known that the antimicrobial activity of Ag NP depends on their adsorption on the microorganism membrane, and it is believed that this activity is related to the interaction of Ag NP and thiol groups of membrane proteins (Durán et al. 2010). Several studies have reported that the bactericidal effects of nanoparticles are related to their adsorption to the bacterial cell surface. The studies reported by Sondi and Salopek-Sondi (2004) found an accumulation of Ag NP in the bacterial membrane of $\mathrm{E}$. coli. Also, Morones et al. (2005) showed clear evidence of the adsorption and accumulation of Ag NP in Gramnegative bacteria cells. According to Jiang et al. (2009), the electrostatic force of attraction contributed greatly to the adhesion of nanoparticles on the bacterial cell surfaces, thereby resulting in increased cell death. In a study on interactions, Khan et al. (2011) showed that the survival rate of bacterial species decreased with increase in adsorption of Ag NP. 
Fig. 4 Antibacterial activity (in micrograms per milliliter) of silver nanoparticles L-2-2 and MGE-201 against E. coli ATCC

25922, P. aeruginosa ATCC 27853, M. luteus ATCC 10240, and S. aureus ATCC 25923
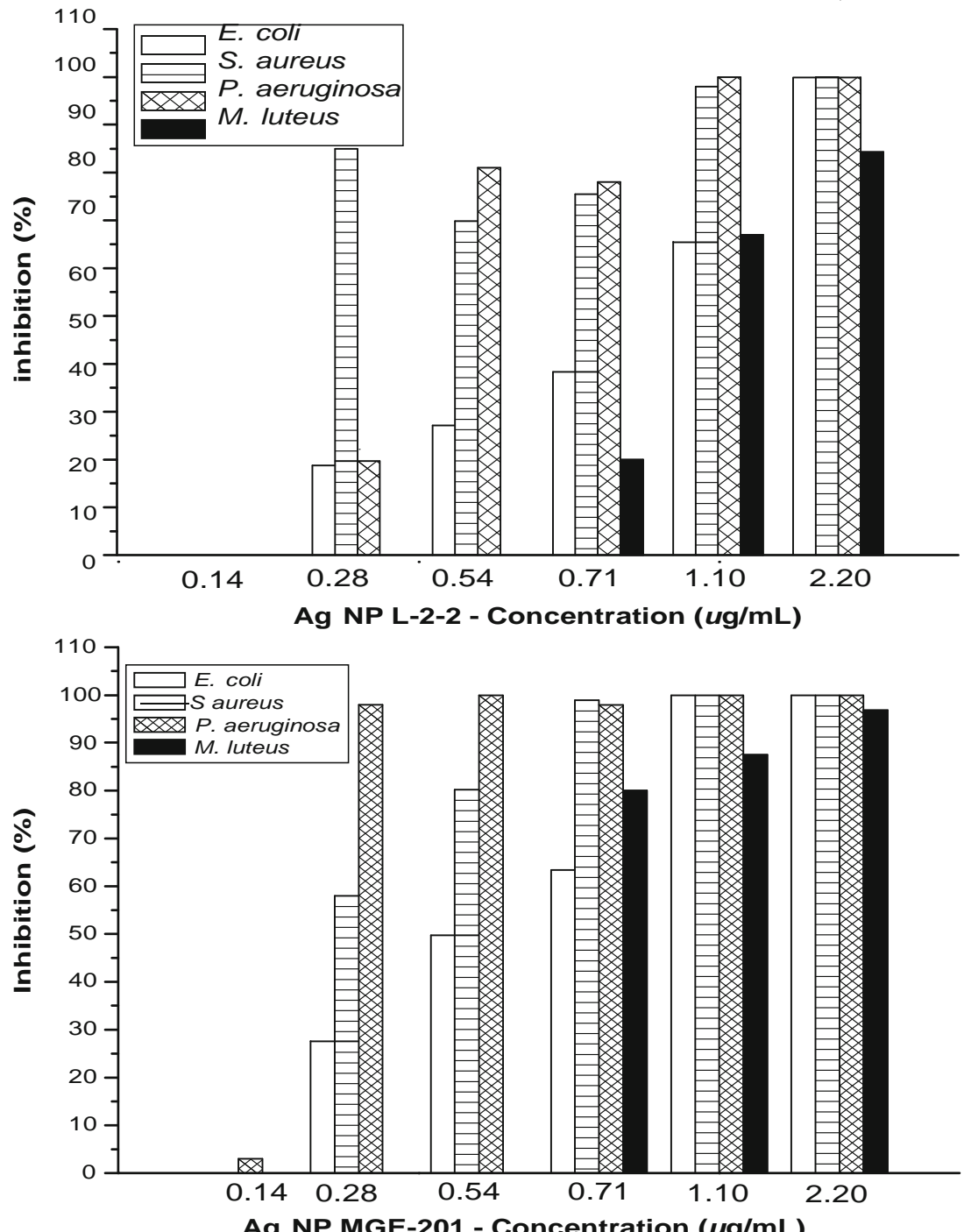

The presence of the same protein bands for the FF and Ag NP of MGE-201 is important, indicating that proteins present in FF remained during the formation of the nanoparticles and even in similar proportions. Furthermore, it is possible to speculate that these proteins stabilized the Ag NP formed by binding to their surfaces.

For L-2-2, FF and Ag NP protein bands demonstrated different molecular weight ranges and proportions. Interestingly, the proteins bands for Ag NP showed lower molecular weights compared to FF.

A high antifungal activity was observed for biogenic $\mathrm{Ag}$ NP produced by the fungi L-2-2 and MGE-201. Kim et al. (2008, 2009) also showed the antifungal activity of Ag NP (spherical form with average size of $3 \mathrm{~nm}$ ) produced by chemical methods against C. albicans and in Trichophyton mentagrophytes (ATTC and clinical strains), observing a $\mathrm{MIC}_{80}$ of $1-7 \mu \mathrm{g} / \mathrm{mL}(5.88-41.18 \mu \mathrm{M})$. These data show that the biogenic nanoparticles produced by L-2-2 and MGE-201 were more effective than those obtained through chemical methods. In this study, lower concentrations of the Ag NP were able to inhibit $90 \%$ of fungal growth in comparison to Ag NP obtained by chemical procedures, which inhibited only $80 \%$ of fungal growth at concentrations at least threefold higher.

Despite the positive surface charge, the Ag NP synthesized by fungus MGE-201 showed antifungal activity similar to that of the particles with negative surface charge produced by the fungus L-2-2. However, as can be observed in Fig. 4, the Ag NP of MGE-201 were more effective compared to that of L-2-2 against the bacteria. Notably, Ag NP inhibited the proliferation of both Gram-negative and Gram-positive bacteria and was more effective than the antibacterial gentamicin, which inhibited more than $80 \%$ of the bacterial growth only above $16 \mu \mathrm{g} / \mathrm{mL}$ $(17 \mu \mathrm{M})$. This is the first report of the synthesis of Ag NP using fungi isolated from a Brazilian mangrove, and the data open the possibility of obtaining biogenic Ag NP with positive surface potential and new applications. 
Acknowledgments This study was supported by Fundação de Amparo à Pesquisa do Estado de São Paulo. Dr. A. Leyva helped with the English editing of the manuscript and Prof. Nelson Durán with PCS equipment.

Conflict of interest The authors declare that they have no conflict of interest.

\section{References}

Araújo WL, Maccheroni W Jr, Aguillar-Vildoso CI, Barroso PAV, Saridakis HO, Azevedo JL (2001) Variability and interactions between endophytic bacteria and fungi isolated from leaf tissues of citrus rootstocks. Can J Microbiol 47:229-236. doi:10.1139/ cjm-47-3-229

Bradford M (1976) A rapid and sensitive method for the quantitation of microgram quantities of protein utilizing the principle of protein- dye binding. Anal Biochem 72:248-254. doi:10.1016/0003-2697 (76)90527-3

Bulet P, Dinamarq JL, Hetru C, Lagueux M, Charlet M, Hegy G, Dorsselaer AV, Hoffmann JA (1993) A novel inducible antibac- terial peptide of Drosophila carries an O-glycosylated substitu- tion. J Biol Chem 268:14893-14897, http://hwmaint.jbc.org/cgi/ reprint/268/20/14893

CLSI. Clinical and Laboratory Standards Institute (2002) Norma M27-

A2. Método de referência para testes de diluição em caldo para a determinação da sensibilidade de leveduras a terapia antifúngica: Norma aprovada. 2. ed. Pennsylvania/Estados Unidos: Edição Wayne, vol. 22, 55 p

Durán N, Marcato PD, Alves OL, De Souza GIH, Esposito E (2005) Mechanistic aspects of biosynthesis of silver nanoparticles by several Fusarium oxysporum strains. J Nanobiotechnol 3:1-7. doi:10.1186/1477-3155-3-8

Durán N, Marcato PD, De Souza GIH, Alves OL, Esposito E (2007) Antibacterial effect of silver nanoparticles produced by fungal process on textile fabrics and their effluent treatment. J Biomed Nanotechnol 3:203-208. doi:10.1166/jbn.2007.022

Durán N, Marcato PD, Ingle A, Gade A, Rai M (2010) Fungi-mediated synthesis of silver nanoparticles: characterization processes and appli- cations. Prog Mycol 425-449. doi:10.1007/978-90-481-3713-8_16

Gade A, Bonde P, Ingle AP, Marcato PD, Durán N, Rai MK (2008) Exploitation of Aspergillus niger for synthesis of silver nano- particles. J Biobased Mater Bioenerg 2:243-247. doi:10.1166/jbmb.2008.401

González-Mendoza D, Argumedo-Delira R, Morales-Trejo A, Pulido- Herrera A, Cervantes-Díaz L, Grimaldo-Juarez O, Alarcón A (2010) A rapid method for isolation of total DNA from pathogen- ic filamentous plant fungi. Genet Mol Res 9:162-166. doi:10.4238/vol91 gmr680

Jiang W, Mashayekhi H, Xing B (2009) Bacteria toxicity comparison between nano- and micro-scaled oxide particles. Environ Pollut 157:1619-1625. doi:10.1016/j.envpol.2008.12.025

Kathiresan K, Manivannan S, Nabeel MA, Dhivya B (2009) Studies on silver nanoparticles synthesized by a marine fungus, Penicillium fellutanum isolated from coastal mangrove sediment. Colloids Surf B Biointerfaces 71:133-137. doi:10.1016/j.colsurfb.2009.01.016

Kathiresan K, Alikunhi NM, Pathmanaban S, Nabikhan A, Kandasamy S (2010) Analysis of antimicrobial silver nanoparticles synthe- sized by coastal strains of Escherichia coli and Aspergillus niger. Can J Microbiol 56:1050-1059. doi:10.1139/W10-094

Khan SS, Mukherjee A, Chandrasekaran N (2011) Studies on interac-tion of colloidal silver nanoparticles (SNPs) with five different bacterial species. Colloids Surf B Biointerfaces 87:129-138. doi:10.1016/j.colsurfb.2011.05.012

Kim KJ, Sung WS, Moon SK, Choi JS, Kim JG, Lee DG (2008) Antifungal effect of silver nanoparticles on dermatophytes. J Microbiol Biotechnol 18:1482-1484

Kim KJ, Sung WS, Kyoung SB, Suh BK, Moon SK, Choi JS, Kim J, Lee DG (2009) Antifungal activity and mode of action of silver nanoparticles on Candida albicans. BioMetals 22:235-242. doi:10.1007/s10534-008-9159-2

Kimura M (1980) A simple method for estimating evolutionary rates of base substitutions through comparative studies of nucleotide sequences. J Mol Evol 16:111-120. doi:10.1007/BF01731581

Li B, Logan BE (2004) Bacterial adhesion to glass and metal-oxide surfaces. Colloids Surf B Biointerfaces 36:81-90. doi:10.1016/ j.colsurfb.2004.05.006

Li WR, Xie XB, Shi QS, Zeng HY, Ou-Yang YS, Chen YB (2010) Antibacterial activity and mechanism of silver nanoparticles on Escherichia coli. Appl Microbiol Biotechnol 85:1115-1122. doi:10.1007/s00253-009-2159-5

Li WR, Xie XB, Shi QS, Duan SS, Ouyang YS, Chen YB (2011) Antibacterial effect of silver nanoparticles on Staphylococcus aureus. BioMetals 24:135-141. doi:10.1007/s10534-010-9381-6

Morones JR, Elechiguerra JL, Camacho A, Holt K, Kouri JB, Ramirez

JT, Yacaman MJ (2005) The bactericidal effect of silver nano- particles. Nanotechnology 16:2346-2353. doi:10.1088/0957$4484 / 16 / 10 / 059$

Musarrat J, Dwivedi S, Singh BR, Al-Khedhairy AA, Azam A, Naqvi A (2010) Production of antimicrobial silver nanoparticles in water extracts of the fungus Amylomyces rouxii strain KSU-09. Bioresour Technol 101:8772-8776. doi:10.1016/j.biortech.2010.06.065

Palomino JC, Martin A, Camacho M, Guerra H, Swings J, Portaels F (2002) Resazurin microtiter assay plate: simple and inexpensive method for detection of drug resistance in Mycobacterium tuber- culosis. A ntimicro b A g e nts C hemot h er $46: 2720-2722$. doi:10.1128/AAC.46.8.2720-2722.2002

Raeder U, Broda P (1985) Rapid preparation of DNA from filamentous fungi. Lett Appl Microbiol 1:17-20. doi:10.1111/j.1472765X.1985.tb01479.x

Saitou N, Nei M (1987) The neighbor-joining method: a new method for reconstructing phylogenetic trees. Mol Biol Evol 4:406-425. doi:07374038/87/0404-0007\$02.00

Sondi I, Salopek-Sondi B (2004) Silver nanoparticles as antimicrobial agent: a case study on E. coli as a model for Gram-negative bacteria. J Colloid Interface Sci 275:177-182. doi:10.1016/ j.jcis.2004.02.012

Tamura K, Dudley J, Nei M, Kumar S (2007) MEGA4: Molecular Evolutionary Genetics Analysis (MEGA) software version 4.0. Mol Biol Evol 24:1596-1599. doi:10.1093/molbev/msm092

Thompson JD, Higgins DG, Gibson TJ (1994) CLUSTAL W: improv- ing the sensitivity of progressive multiple sequence alignment through sequence weighting, position-specific gap penalties and weight matrix choice. Nucleic Acids Res 22:4673-4680. 
doi:10.1093/nar/22.22.4673

Warren NG, Shadomy HJ (1991) Yeasts of medical importance. In: Balows A, Hausler WJ Jr, Herrmann KL, Isenberg HD, Shadomy HJ (eds) Manual of clinical microbiology, 5th edn. ASM, Washington

Zhang X, Yan S, Tyagi RD, Surampalli RY (2011) Synthesis of nano- particles by microorganisms and their application in enhancing microbiological reaction rates. Chemosphere 82:489-494. doi:10.1016/j.chemosphere.2010.10.023 
ANEXO A - Análise de proteínas presentes no FF e dispersão de NP Ag obtidas a partir do fungo MGE201 por Cromatografia Líquida acoplada a Espectrometria de Massas (LC-MS)

Os dados obtidos, as Figuras 8 e 9 (FF), e 11 e 12 (NP Ag) mostram espectros de fragmentação dos peptídeos de maior score das proteínas identificadas para filtrado fúngico de MGE-201. Já as Figuras 7 e 10 mostram a distribuição estatística obtida. Os valores de scores (avaliação da significância do resultado) fora da área hachurada (para o FF e NP Ag os scores são $\geq 52$, e $\geq 53$, respectivamente) possuem estatística confiável para a identificação de peptídeos tendo uma probabilidade $\leq 5 \%$ de serem falsos positivos ou eventos aleatórios.

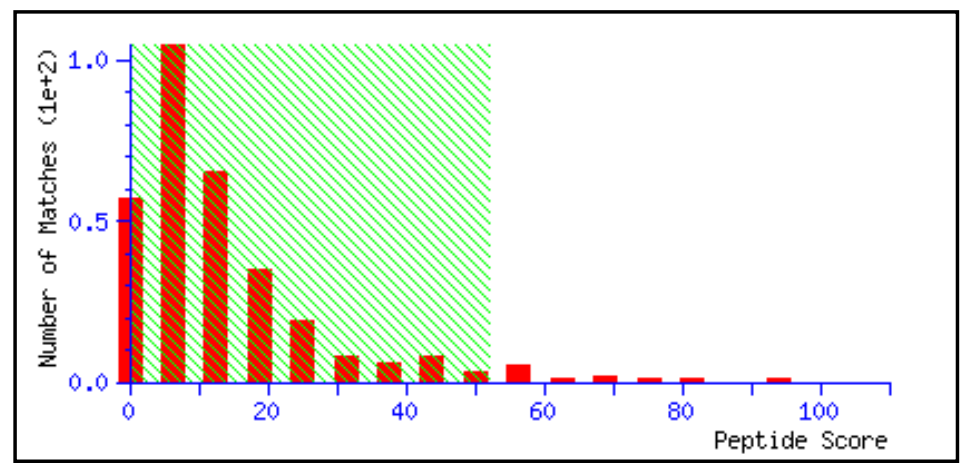

Figura 1 - Distribuição estatística para o score dos peptídeos identificados para o filtrado fúngico de MGE-201 busca pelo Mascot.

1) Proteína hipotética - An01g11010 [Aspergillus niger]

score: 93

Massa nominal $\left(\mathrm{M}_{\mathrm{r}}\right)$ : 39862; Valor PI calculado: 4,06

1 MYFSKTAVAL AAVLPLATAQ TYTDCDPLNK TCPADTALSS TTFTTDFTTG

51 SFSGWIATAN NVTFTDEGAN FVISEKGEAP TIETDFYFFF GKAEVVMKAA

101 SGTGICSSVV LESDDLDEID WEALGGDTTQ IETNYFGKGD TSSYDRATWA

151 TVSTPQETFH TYTVEWTESA TTWSIDGTVV RTLAYSDAQS GTRYPQTPMR

201 LKLGIWAAGD SSEPEGTIEW AGGETDYSDG PFTMTVKSVS ITNYNPGSSY

251 TYSDKTGDYT SIVVNNGTSS SSVSSTTGST SSSTSSSTSS SSSSTSSSDS

301 TSSSGSTSSS GSSTSSGSST SASSAAAAGS SSALIGSGSS TSSGSSAAGS

351 GAASASGSAS ASSSASASAS PVYTGAATHV GASTSVLFAG LLAALL 


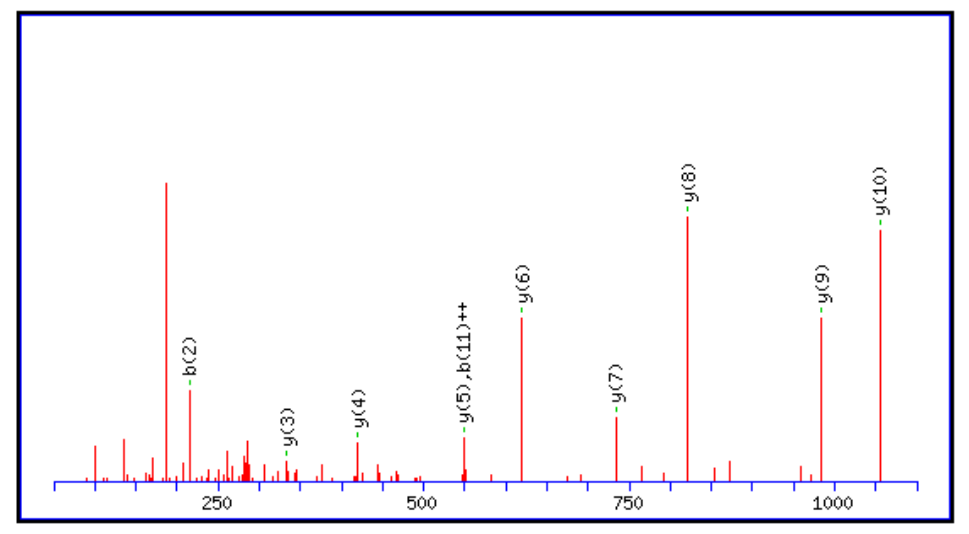

Figura 2 - Espectro de fragmentação do peptídeo TLAYSDAQSGTR identificado por LC-MS no filtrado fúngico de MGE-201.

2) preproglicoamilase G2 [Aspergillus niger]

Score: 61

Massa nominal $\left(M_{r}\right)$ : 56695; Valor PI calculado: 4,41

1 MSFRSLLALS GLVCTGLANV ISKRATLDSW LSNEATVART AILNNIGADG

51 AWVSGADSGI VVASPSTDNP DYFYTWTRDS GLVLKTLVDL FRNGDTSLLS

101 TIENYISAQA IVQGISNPSG DLSSGAGLGE PKFNVDETAY TGSWGRPQRD

151 GPALRATAMI GFGQWLLDNG YTSTATDIVW PLVRNDLSYV AQYWNQTGYD

201 LWEEVNGSSF FTIAVQHRAL VEGSAFATAV GSSCSWCDSQ APEILCYLQS

251 FWTGSFILAN FDSSRSGKDA NTLLGSIHTF DPEAACDDST FQPCSPRALA

301 NHKEVVDSFR SIYTLNDGLS DSEAVAVGRY PEDTYYNGNP WFLCTLAAAE

351 QLYDALYQWD KQGSLEVTDV SLDFFKALYS DAATGTYSSS SSTYSSIVDA

401 VKTFADGFVS IVETHAASNG SMSEQYDKSD GEQLSARDLT WSYAALLTAN

451 NRRNSVVPAS WGETSASSVP GTCAATSAIG TYSSVTVTSW PSIVATGGTT

501 TTATPTGSGS VTSTSKTTAT ASKTSTTTRS GMSL 


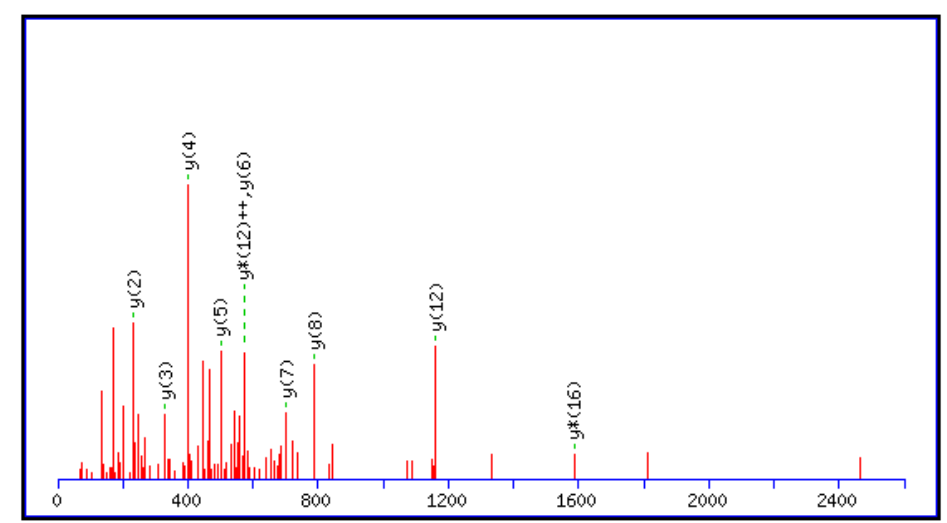

Figura 3 - Espectro de fragmentação do peptídeo SIYTLNDGLSDSEAVAVGR identificado por LC-MS no filtrado fúngico de MGE-201.

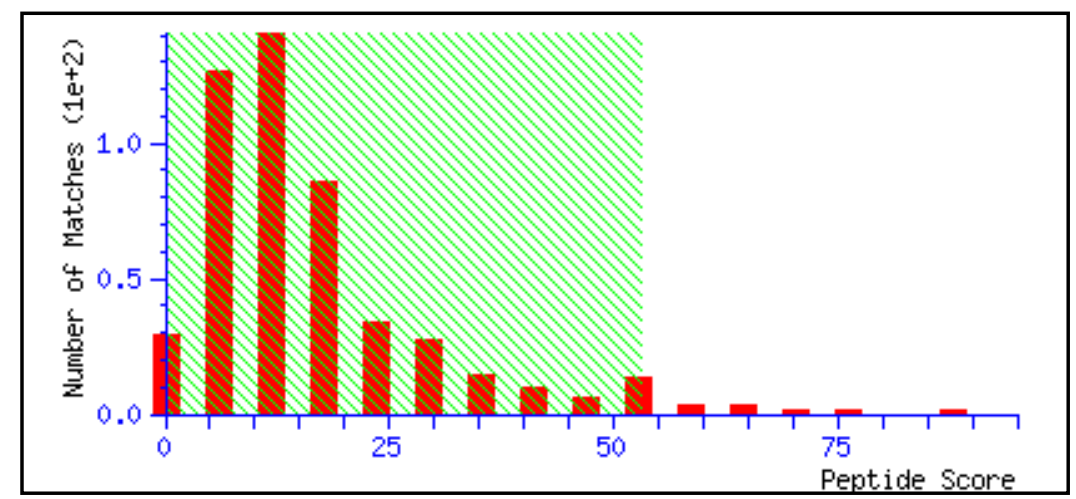

Figura 4 -Distribuição estatística para o score dos peptídeos identificados para nanopartículas de prata sintetizadas a partir da cultura do fungo MGE-201 - busca pelo Mascot.

1) Proteína hipotética - An04g08730 [Aspergillus niger]

\section{Score: 88}

Massa nominal $\left(M_{r}\right)$ : 58940; Valor PI calculado: 5,08

1 MRSLSLAITL AAGLGARGAA GRDEPSILRR ACPDYTSYAS TGHAPYSGGP

51 LNLPYQRPAA ECRTFVSNAV EQVIDDVTSR MVDKDMAQLF RNAFPNTLDT

101 TIRWHVNSTS TTSSSRKMRR DSSQWQGAQT FVVTGDINAE WLRDSTNQLT

151 GYQTLAKKDP ALYNLILGAI HTQAEFVIQS PYCNAFQPPP PSGIQATNNG

201 QQDTVHPAYE PSVVYECKYE LDSLANFLAL GNEFYENTGS TEFLTSRWYL

251 ALDTLLNTTD AQSQPTFNSN RQYVQNQYTF QRQTTLGTET LNLAGIGNPL

301 NGGTGLIRSA FRPSDDATIL GFFIPANAMM SVQLKKTADL IRAAGGDSAL 
351 ASNLQTRGEN LEQAVRQHGI FNHEKYGEVY AFEVDGYGSR IFMDDANIPS

401 LLALPYLGFV DKSDQVYQNT RKMILDPNGN PYYLTGSDFH GIGGPHIGLE 451 NAWPMSLLVQ ALTTDNVTEI TESLNIVRNS SLLGLVHESI DVNNIKSYTR 501 PWFAWANSVF SQTILKVAAE QPEVLFGDGA EPYVIS

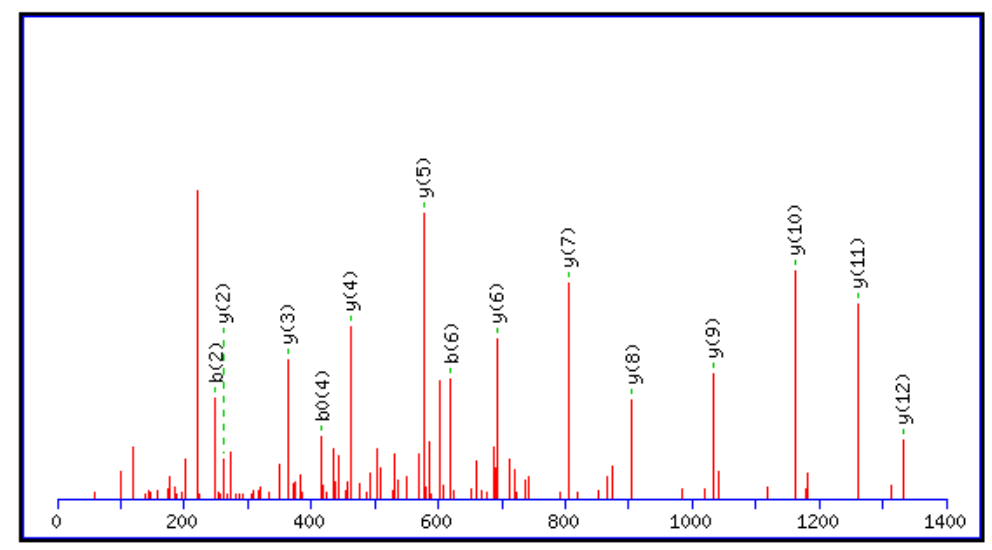

Figura 5 - Espectro de fragmentação do peptídeo TFVSNAVEQVIDDVTSR identificado por LC-MS na dispersão de NP obtida a partir da cultura do fungo MGE-201.

2) Fosfatase ácida [Aspergillus niger]

Score: 85

Massa nominal $\left(M_{r}\right)$ : 52725; Valor Pi calculado: 4,57

1 MPRTSLLTLA RALATGASAF PYGAAIPQST QEKQFSQEFR DGYSILKHYG

51 GNRPYSERVS YGIARDPPTG CEVDQVIMVK RHGERYPSPS AGKSIEEALA

101 KVYSINTTEY KGDLAFLNDW TYYVPNECYY NAETTSGPYA GLLDAYTHGN

151 EYKARYGHLW DGETVVPFFS SGYGRVIETA RKFGEGFFGY NYSTNAALNI

201 ISESEVMGAD SLTPTCDTDN DQTICDDLTY QLPQFKVAAA RLNSQNPGMN

251 LTASDVYNLM VMASFELNAR PFSNWINAFT QDEWVSFGYV EDLDYYYCAG

301 PGDKNMAAVG AVYANASLTL LNQGPKEAGS LFFNFAHDTN ITPILAALGV

351 LIPDEDLPLD RVAFGNPYSI GNIVPMGGHL TIERLSCQAT ALSDEGTYVR

401 LVLNEAVLPF NDCTSGPGYS CPLANYTAIL NKDLPDYTTT CNVSASYPQH 
451 LSFWWNYNTT TELNYRSSPI ACQEGDAMD

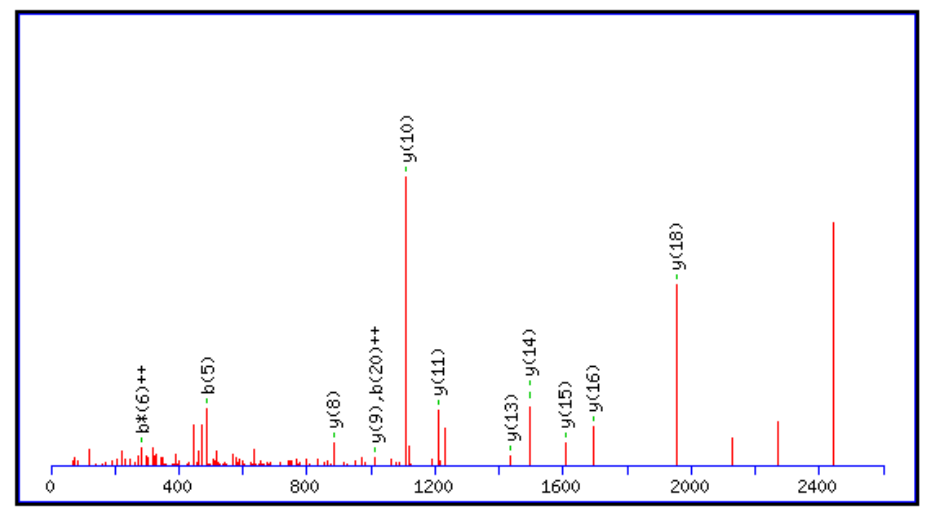

Figura 6 - Espectro de fragmentação do peptídeoVAFGNPYSIGNIVPMGGHLTIER identificado por LC-MS na dispersão de NPobtido a partir da cultura do fungo MGE-201. 
ANEXO B - Árvores fenéticas construídas a partir dos fungos L-2-2, MGE-201 e R-2BI-4

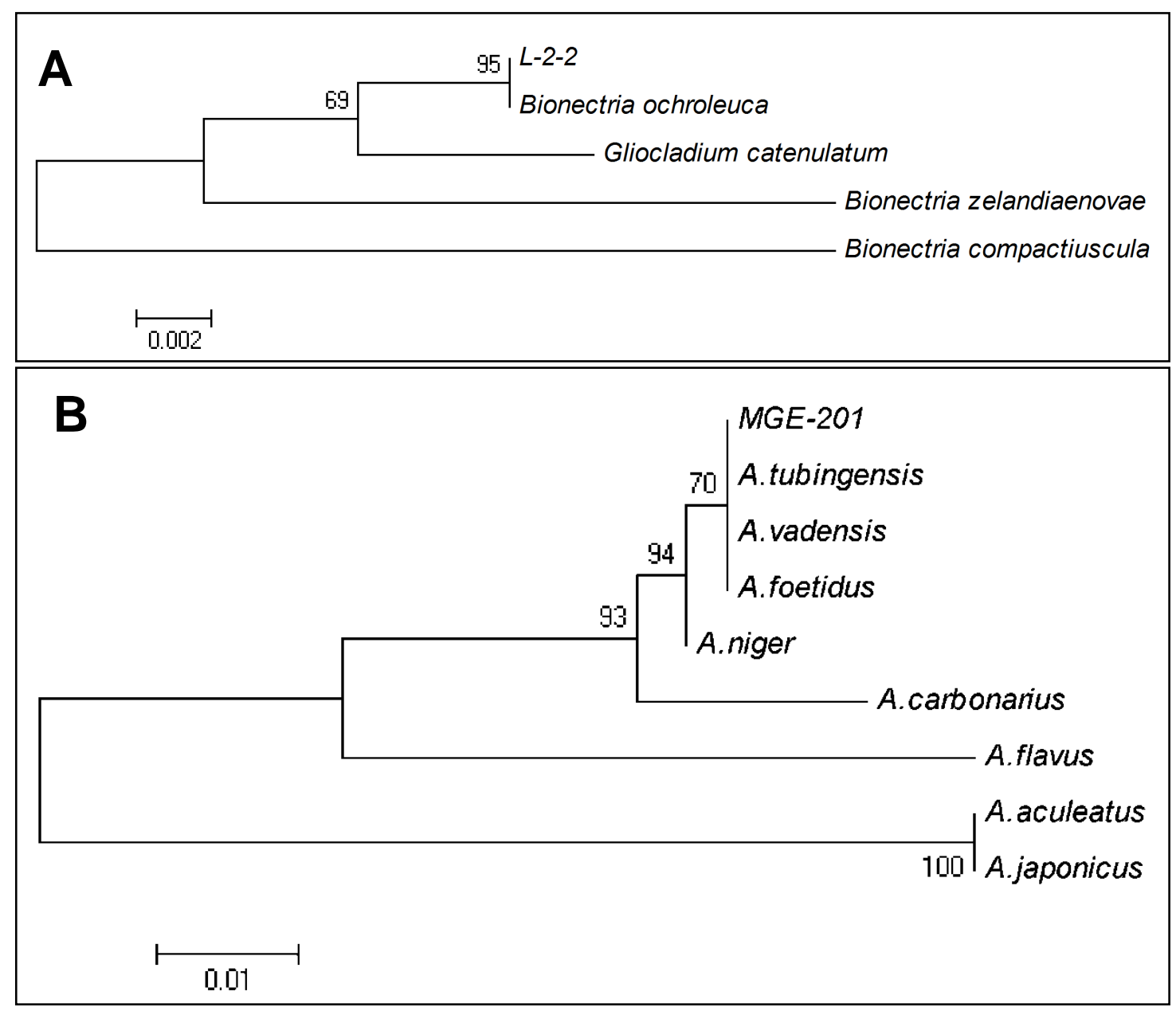

Figura 1 - (A) Árvore fenética com relação filogenética entre a sequencia parcial do operon ribosomal ITS1-5.8SITS2 do fungo L-2-2 e sequencias de linhagens de microrganismos relacionados presentes no banco de dados CBS (B. ochroleuca CBS 102.94, G. catenulatum CBS 227.48, B. zelandiaennovae CBS 232.80 e B. compactiuscula CBS 919.97). (B) Árvore filogenética com relação filogenética entre a sequencia parcial do operon ribossomal ITS1-5.8S-ITS2 do fungo MGE-201 e sequencias de linhagens de microrganismos presentes no banco de dados CBS e GenBank (A. tubingensis: CBS 12652, AY585546, A. vadensis: CBS113365, AY585551, A. foetidus var. acidus: CBS 56465, AY585551, A. niger: CBS12049, AY585553, A. carbonarius: CBS 11126, AY585550, A. flavus: NRRL 1957 (AF027863), A. Japonicus: CBS 10114 (AY585561), A. aculeatus: CBS 17266, AY585558). 


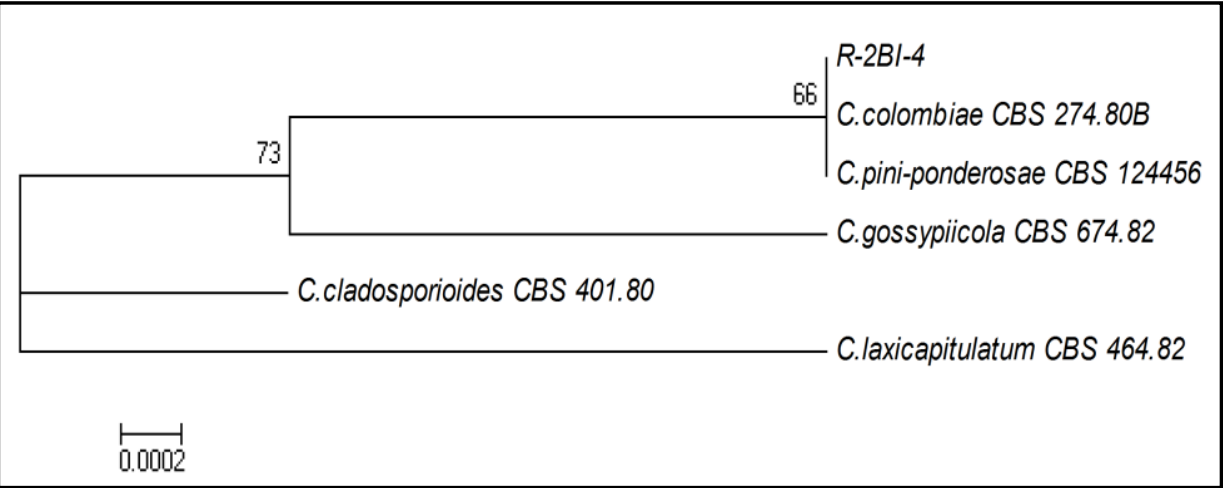

Figura 2 - Árvore fenética com sequencia parcial do operon ribossomal ITS1-5.8S-ITS2 do fungo R-2BI-4 e sequencias de linhagens de microrganismos relacionados presentes no banco de dados CBS $(C$. colombiae, C. pini-ponderosae, C. gossypiicola, C. cladosporioides, C. laxicapitulatum). 